Gabriela Silveira

\title{
Narrativas produzidas por indivíduos afásicos e indivíduos cognitivamente sadios: análise computadorizada de macro e micro estrutura
}

\begin{abstract}
Dissertação apresentada à Faculdade de Medicina da Universidade de São Paulo para obtenção do título de Mestre em Ciências
\end{abstract}

\author{
Programa de Ciências da Reabilitação \\ Área de Concentração: Ciências da \\ Reabilitação \\ Orientadora: Profa. Dra. Letícia Lessa \\ Mansur
}

(Versão corrigida. Resolução CoPGr 6018/11, de 13 de outubro de 2011. A versão original está disponível na Biblioteca da FMUSP)

\section{São Paulo}


Gabriela Silveira

\title{
Narrativas produzidas por indivíduos afásicos e indivíduos cognitivamente sadios: análise computadorizada de macro e micro estrutura
}

\begin{abstract}
Dissertação apresentada à Faculdade de Medicina da Universidade de São Paulo para obtenção do título de Mestre em Ciências
\end{abstract}

\author{
Programa de Ciências da Reabilitação \\ Área de Concentração: Ciências da \\ Reabilitação \\ Orientadora: Profa. Dra. Letícia Lessa \\ Mansur
}

(Versão corrigida. Resolução CoPGr 6018/11, de 13 de outubro de 2011. A versão original está disponível na Biblioteca da FMUSP)

\section{São Paulo}




\section{FICHA CATALOGRÁFICA}

\section{Dados Internacionais de Catalogação na Publicação (CIP)}

Preparada pela Biblioteca da

Faculdade de Medicina da Universidade de São Paulo

Creprodução autorizada pelo autor

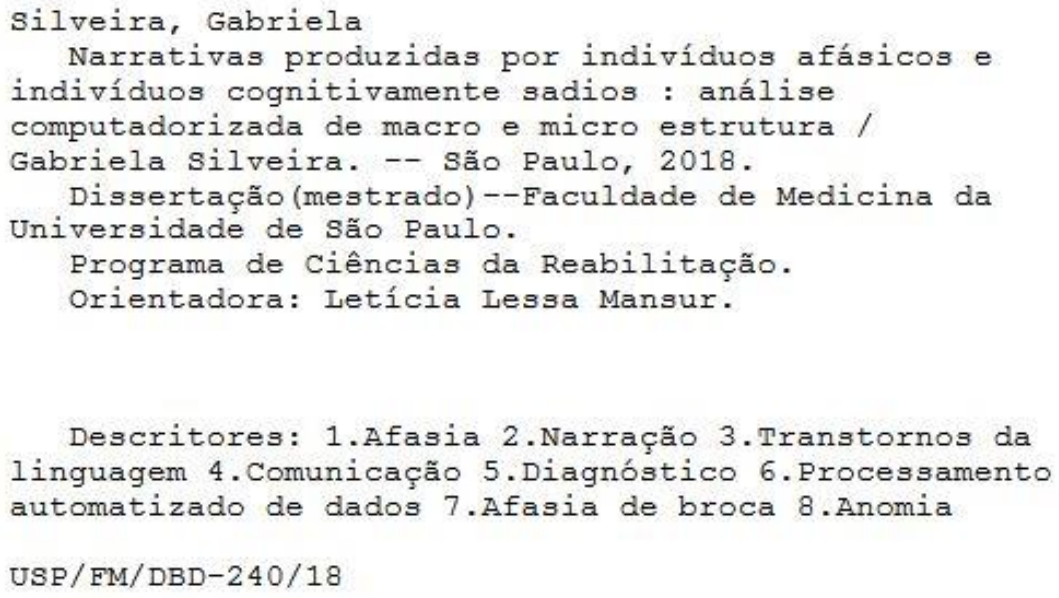

Responsável: Kátia Maria Bruno Ferreira - CRB-8/6008 


\section{DEDICATÓRIA}

Ao meu Deus, à minha Nossa Senhora è minha família com todo amor.

"Consagre ao Senhor tudo o que você faz, e os seus planos serão bemsucedidos." 


\section{AGRADECIMENTOS}

A Deus, por ter me escolhido para seguir o caminho desta profissão, de poder fazer a diferença na vida das pessoas e por ter me fortalecido e me abençoado em todos os momentos de minha vida. A minha mãe Nossa Senhora, que sempre me protegeu com seu manto de amor e nunca me desamparou em momentos de tormenta.

Aos meus pais, Sérgio Luís Silveira e Andreia Cristina Pereira Silveira, que se dedicaram exclusivamente à minha educação com todo o amor e o sacrifício, estiveram presentes em todas as minhas conquistas, nunca permitiram que eu fosse vencida pelos obstáculos e me incentivaram a nunca desistir dos meus sonhos. A minha família que colaborou para a minha formação como pessoa e profissional, acompanhando todo o meu processo de crescimento, e me dando todo o amor que cabe em seus corações. A minha avó Iva, in memorian, que com toda a sua bondade me ensinou a dedicação pelo próximo.

À minha querida orientadora, Profa. Dra. Leticia Lessa Mansur, por toda a dedicação, confiança, paciência e carinho comigo durante toda esta caminhada. Eu sou muito grata por todos os seus ensinamentos. Obrigada por ter me tornado a profissional que eu sou hoje.

À querida Dra. Lucia Iracema Zanotto de Mendonça, por todo o seu apoio, seus ensinamentos e sua atenção para comigo.

À Dra. Sandra Maria Aluísio, pela disponibilidade de me auxiliar neste processo e por toda a ajuda.

Ao colega Leandro Borges dos Santos, que sempre esteve de prontidão para me ajudar e para tornar este trabalho possível, realizando a análise computadorizada dos dados.

Às Dra. Ariella Fornachari Ribeiro e Dra. Nair Katia Nemr, que colaboraram com sugestões preciosas para este trabalho no processo de qualificação. 
À minha amiga Cíntia Matsuda Toledo, que sempre esteve ao meu lado, como uma parceira pessoal, profissional e pesquisadora, me apoiando em todas as circunstâncias. A minha amiga Marcela Lima Silagi de Siqueira, por toda sua colaboração em minha formação e apoio desde o momento em que entrei na graduação até hoje. A minha amiga Tharsila Moreira Gomes da Costa, pelos ensinamentos e por ser minha parceira de todos os momentos.

Aos amigos, pacientes, familiares e colaboradores que participaram deste estudo, minha gratidão. 


\section{NORMALIZAÇÃO ADOTADA}

Esta dissertação está de acordo com as seguintes normas, em vigor no momento desta publicação:

Referências: adaptado de International Committee of Medical Journals Editors (Vancouver).

Universidade de São Paulo. Faculdade de Medicina. Divisão de Biblioteca e Documentação. Guia de apresentação de dissertações, teses e monografias. Elaborado por Anneliese Carneiro da Cunha, Maria Julia de A. L. Freddi, Maria F. Crestana, Marinalva de Souza Aragão, Suely Campos Cardoso, Valéria Vilhena. 3a ed. São Paulo: Divisão de Biblioteca e Documentação; 2011.

Abreviaturas dos títulos dos periódicos de acordo com List of Journals Indexed in Index Medicus. 


\section{SUMÁRIO}

\section{Lista de Abreviaturas}

Lista de Tabelas

Lista de Figuras

Lista de Anexos

Resumo

Abstract

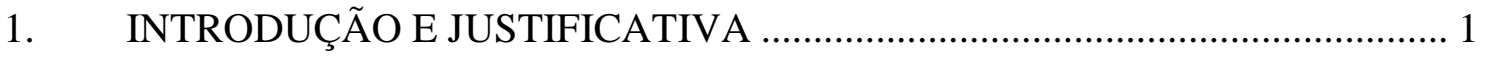

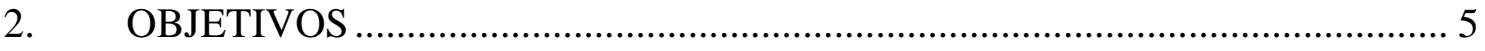

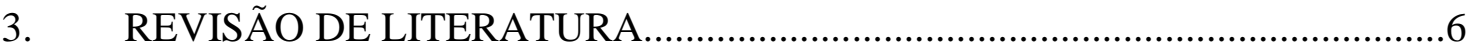

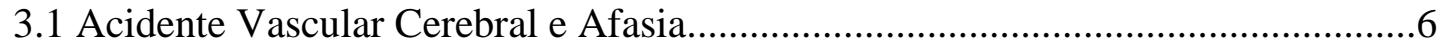

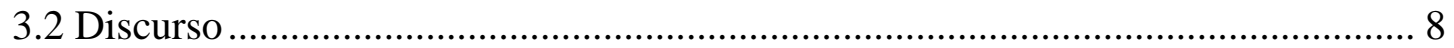

3.2.1 Avaliação de linguagem de afásicos: discurso ............................................ 8

3.2.2 Definição de discurso: microestrutura e macroestrutura ............................... 9

3.2.3 Técnicas de elicitação e gêneros discursivos.............................................. 11

3.3 Análise computadorizada e discurso ............................................................... 15

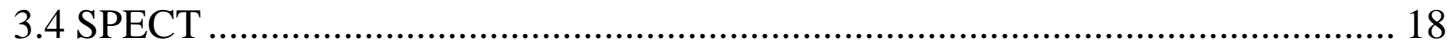

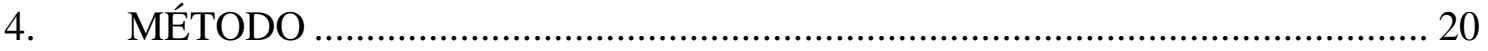

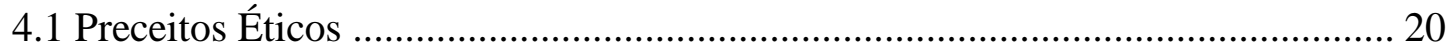

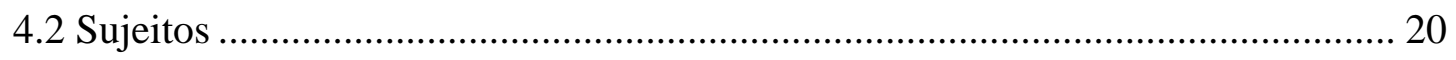

4.2.1 Critérios de inclusão e exclusão: ........................................................ 21

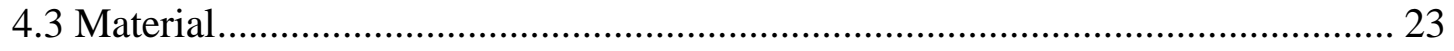

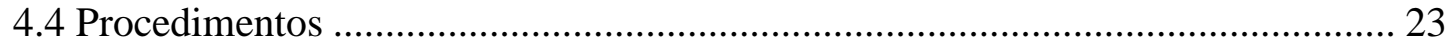

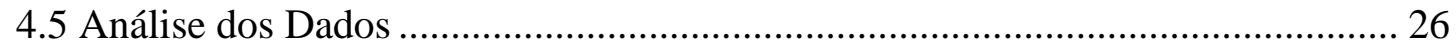

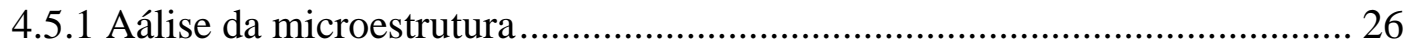

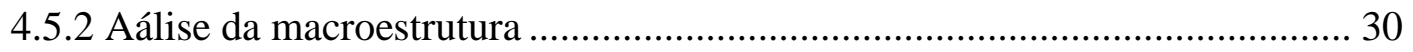

4.5.3 Aálise estatística .................................................................................... 34

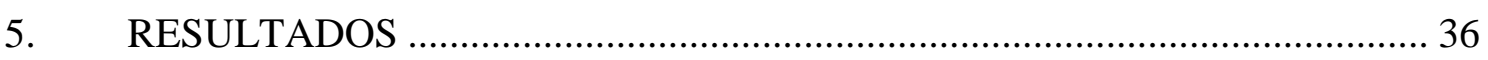

5.1 Composição e Caracterização da Amostra ............................................................ 36

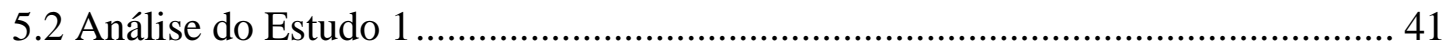




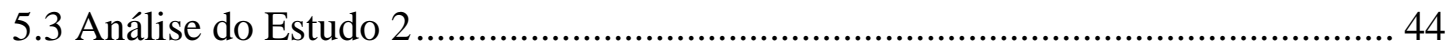

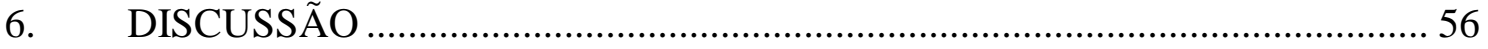

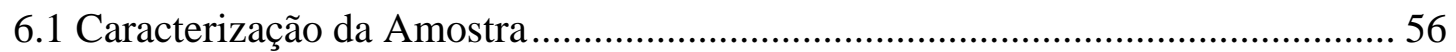

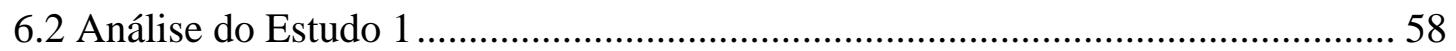

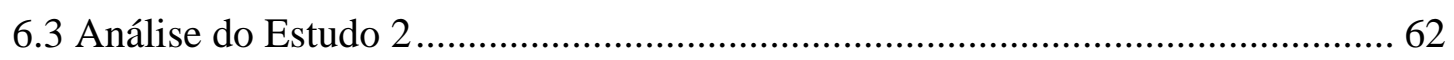

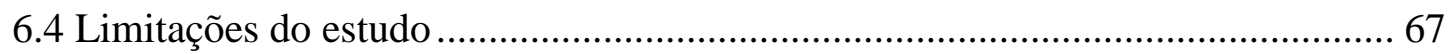

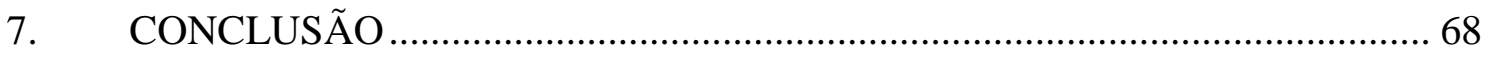

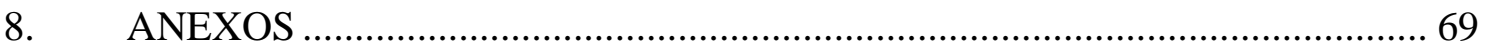

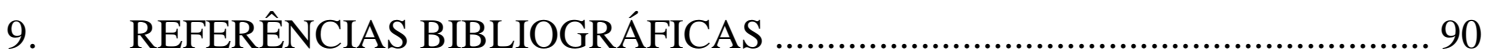




\section{LISTA DE ABREVIATURAS}

AVC - Acidente Vascular Cerebral

CAPPesq - Comissão de Ética para Análise de Projetos de Pesquisa

CHILDES - Child Language Data Exchange System

CLAN - Computerized Language Analysis

DeepBonDD - Deep neural approach to Boundary and Disfluency Detection

FMUSP - Faculdade de Medicina da Universidade de São Paulo

FV - Fluência Verbal

GC - Grupo controle

G1 - Grupo Afásicos 1

G2 - Grupo Afásicos 2

HCFMUSP - Hospital das Clínicas da Faculdade de Medicina da Universidade de São Paulo

LDC - Linguistic Data Consortium

MEEM - Mini Exame do Estado Mental

MOANS - Mayo Older American Normative Studies

NILC - Núcleo interinstitucional de Linguística Computacional

PLN - Processamento de Linguagem Natural

SPECT - Tomografia computadorizada por emissão de fóton único

TC - Tomografia computadorizada

TCLE - Termo de Consentimento Livre e Esclarecido 


\section{LISTA DE TABELAS}

Tabela 1 - Resultados das avaliações Fluência Verbal - animais e fonêmica e MEEM dos indivíduos cognitivamente sadios. 36

Tabela 2 - Características dos sujeitos do G1 38

Tabela 3- Resultados de exames de imagem que mostram os locais de lesão do G1 .... 39

Tabela 4 - Características dos sujeitos do G2 40

Tabela 5 - Comparação do discurso no nível de macroestrutura e microestrutura entre o GC e o G2. História da "Cinderela" 41

Tabela 6 - Comparação de discurso (nível macro e microestrutura), segundo tipo de Síndrome de Afasia. História Cinderela $(\mathrm{n}=15)$

Tabela 7 - Comparação de discurso no nível de macroestrutura e microestrutura, segundo tempo de acompanhamento. História Biscoito $(\mathrm{n}=8)$ 45

Tabela 8 - Comparação entre os índices de proporções de acertos (macro) para história Biscoito, até um mês após AVC

Tabela 9 - Comparação entre os índices de proporções de acertos (macro) para história Biscoito, 3 meses após AVC

Tabela 10 - Comparação entre os índices de proporções de acertos (macro) para história Biscoito, 6 meses após AVC 47

Tabela 11 - Comparação de discurso no nível de macroestrutura e microestrutura, segundo tipo de Síndrome de Afasia. História Biscoito

Tabela 12 - Comparação de discurso no nível de macroestrutura e microestrutura, segundo tempo de acompanhamento. História Cinderela $(n=8)$.

Tabela 13 - Comparação entre os índices de proporções de acertos (macro) para história Cinderela entre os afásicos, até um mês após AVC.

Tabela 14 - Comparação entre os índices de proporções de acertos (macro) para história Cinderela entre os afásicos, 3 meses após AVC

Tabela 15 - Comparação entre os índices de proporções de acertos (macro) para história Cinderela entre os afásicos, 6 meses após AVC

Tabela 16 - Comparação dos valores medianos dos parâmetros microestruturais entre os afásicos $(\mathrm{n}=8)$, segundo tipo de história em cada fase do seguimento (início, após 3 meses e após 6 meses) 
Tabela 17 - Comparação dos valores medianos dos parâmetros macroestruturais entre os afásicos $(n=8)$, segundo tipo de história em cada fase do seguimento (início, após 3 meses e após 6 meses) 


\section{LISTA DE FIGURAS}

Figura 1 - Fluxograma dos procedimentos do G1 ......................................................25

Figura 2 - Processo de inclusão dos sujeitos no G1 37 


\section{LISTA DE ANEXOS}

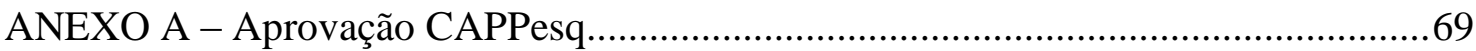

ANEXO B - Termo de Consentimento Livre e Esclarecido.......................................... 71

ANEXO C - Mini Exame do Estado Mental (MEEM)................................................. 77

ANEXO D - Teste de Fluência Verbal...................................................................... 79

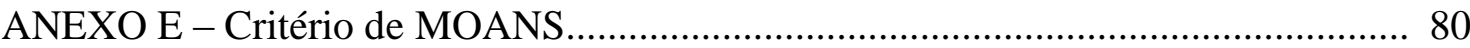

ANEXO F - Escala de gravidade da afasia........................................................ 81

ANEXO G - Escala de Iinteligibilidade....................................................... 84

ANEXO H - Teste de Boston para o Diagnóstico da Afasia .................................. 85

ANEXO I - Prancha “Roubo dos Biscoitos"......................................................... 86

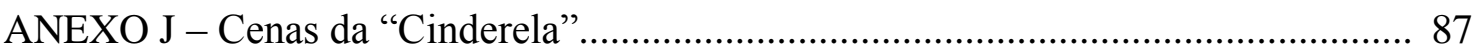

ANEXO K - Critérios para transcrição - princípios do NURC/SP No. 338EF e 331 D $^{2} 88$ 


\section{Resumo}

Silveira G. Narrativas produzidas por indivíduos afásicos e indivíduos cognitivamente sadios: análise computadorizada de macro e micro estrutura [dissertação]. São Paulo: Faculdade de Medicina, Universidade de São Paulo; 2018.

INTRODUÇÃO: O tema de investigação, discurso de afásicos, fornece informações importantes sobre aspectos fonológicos, morfológicos, sintáticos, semânticos e pragmáticos da linguagem de pacientes que sofreram lesão vascular cerebral. Uma das maneiras de estudar o discurso é por meio de cenas figurativas temáticas simples ou em sequência. A sequência da história de "Cinderela" é frequentemente utilizada em estudos, por ser familiar em todo o mundo, o que favorece estudos transculturais; por induzir a produção de narrativas, ao invés de descrições, frequentemente obtidas quando se utiliza prancha única para eliciar discursos. Outra vantagem do uso das sequências da "Cinderela" é o fato de gerar material linguístico em quantidade suficiente para análise detalhada. OBJETIVOS: (1) analisar, por meio de tecnologias computadorizadas, aspectos macro e microestruturais do discurso de indivíduos sadios do ponto de vista cognitivo, afásicos de Broca e afásicos anômicos; (2) explorar o discurso como indicador de evolução da afasia; (3) analisar a contribuição do SPECT para verificação de evolução da afasia junto ao discurso. MÉTODO: Participaram do estudo oito indivíduos afásicos de Broca e anômicos que compuseram o grupo do estudo longitudinal (G1), 15 indivíduos afásicos de Broca e anômicos que compuseram o outro grupo de estudo (G2) e 30 cognitivamente sadios (GC). Os participantes foram solicitados a examinar as cenas da história "Cinderela" e depois recontar a história, com suas palavras. Foram exploradas tecnologias computadorizadas e analisados aspectos macro e microestruturais dos discursos produzidos. Para 0 G1, tivermos a particularidade de coleta de discurso também pela prancha "Roubo dos Biscoitos", análise do exame SPECT e acompanhamento longitudinal por um período de seis meses. RESULTADOS: Comparando o GC e o G2, em relação à macroestrutura, notou-se que os afásicos do G2 se diferenciaram significativamente do GC em todas as proposições e, em relação à microestrutura, sete métricas foram capazes de diferenciar ambos os grupos. Houve diferença significante macro e micro estrutural entre os sujeitos afásicos 
de Broca e anômicos. Foi possível verificar diferenças em medidas da macro e da microestrutura no G1 com o avançar do tempo de lesão após AVC. A história da "Cinderela" forneceu dados de microestrutura mais completos do que a prancha "Roubo dos Biscoitos". Os resultados do SPECT permaneceram os mesmos, sem demonstração de mudança com a evolução da afasia. CONCLUSÃO: A produção de narrativa gerou material para análise de macroestrutura e microestrutura, tanto aspectos de macro quanto de microestrutura diferenciaram indivíduos cognitivamente sadios dos sujeitos afásicos. A análise do discurso da "Cinderela" serviu como instrumento para mensurar a melhora da linguagem dos sujeitos afásicos. $O$ uso da ferramenta computacional auxiliou as análises discursivas.

Descritores: afasia; narração; transtornos da linguagem; comunicação; diagnóstico; processamento automatizado de dados. 


\begin{abstract}
Silveira G. Narratives produced by aphasic individuals and cognitively healthy individuals: computerized analysis of macro and micro structure [dissertation]. São Paulo: "Faculdade de Medicina, Universidade de São Paulo"; 2018.

INTRODUCTION: The aphasic discourse analysis provides important information about the phonological, morphological, syntactic, semantic and pragmatic aspects of the language of patients who have suffered a stroke. The evaluation of the discourse, along with other methods, can contribute to observation of the evolution of the language and communication of aphasic patients; however, manual analysis is laborious and can lead to errors. OBJECTIVES: (1) to analyze, by computerized technologies, macro and microstructural aspects of the discourse of healthy cognitive individuals, Broca's and anomic aphasics; (2) to explore the discourse as indicator of the evolution of aphasia; (3) to analyze the contribution of single photon emission computed tomography (SPECT) to verify the correlation between behavioral and neuroimaging evolution data. METHOD: Two groups of patients were studied: GA1, consisting of eight individuals with Broca's aphasia and anomic aphasia, who were analyzed longitudinally from the sub-acute phase of the lesion and after three and six months; GA2 composed of 15 individuals with Broca's and anomic aphasia, with varying times of stroke installation and GC consisting of 30 cognitively healthy participants. Computerized technologies were explored for the analysis of metrics related to the micro and macrostructure of discourses uttered from Cinderela history and Cookie Theft picture. RESULTS: Comparing the $\mathrm{GC}$ and GA2, in relation to the discourse macrostructure, it was observed that the GA2 aphasics differed significantly from the GC in relation to the total number of propositions emitted; considering the microstructure, seven metrics differentiated both groups. There was a significant difference in the macro and microstructure between the discourses of Broca's aphasic subjects and anomic ones. It was possible to verify differences in macro and microstructure measurements in GA1 with the advancement of injury time. In GA1, the comparison between parameters in the sub-acute phase and after 6 months of stroke revealed differences in macrostructure - increase in the number of propositions of the orientation block and of the total propositions. Regarding the
\end{abstract}


microstructure, the initial measures of syllable metrics by word content, incidence of nouns and incidence of content words differed after 6 months of intervention. The variable incidence of missing words in the dictionary showed a significantly lower value after three months of stroke. Cinderella's story provided more complete microstructure data than the Cookie Theft picture. There was no change in SPECT over time, without demonstration of change with the evolution of aphasia. CONCLUSION: The discourse produced from the history of Cinderella and the Cookie Theft picture generated material for macrostructure and microstructure analysis of cognitively healthy and aphasic individuals, made it possible to quantify and qualify the evolution of language in different phases of stroke recuperation and distinguished the behavior of healthy and with Broca's and anomic aphasia, in macro and microstructure aspects. The exploration of computerized tools facilitated the analysis of the data in relation to the microstructure, but it was not applicable to the macrostructure, demonstrating that there is a need for tool adjustments for the discourse analysis of patients. SPECT data did not reflect the behavioral improvement of the language of aphasic subjects.

Descriptors: aphasia; narrative; discourse analysis; language disorders; communication; diagnosis; automated data processing. 


\section{INTRODUCÃO E JUSTIFICATIVA}

O acidente vascular cerebral (AVC) é definido como a perda abrupta de função cerebral devida à falta de fornecimento de sangue. É classificado em isquêmico e hemorrágico. Entre as sequelas decorrentes do AVC, encontra-se a afasia, prejuízo da linguagem que abrange a compreensão e a produção da linguagem oral e escrita (Hallowell, Chapey, 2008).

A afasia pode ser classificada em tipos de acordo com três domínios linguísticos clássicos: fluência, compreensão auditiva e repetição (Berthier et al., 2011). Entre os quadros afásicos, destacaremos a afasia de Broca e a afasia anômica, que serão tratadas nesta pesquisa. A afasia de Broca pode ser definida como alteração de linguagem em que a compreensão está relativamente preservada; a fala é não fluente ou ausente podendo apresentar agramatismo, perseveração, parafasias, anomias; a repetição e a nomeação estão alteradas; e pode vir acompanhada de quadros de alteração em planejamento e programação motora de fala (apraxia de fala) e/ou alteração em execução motora (disartria). Já a afasia anômica é caracterizada pela dificuldade em encontrar palavras durante a fala e denominar objetos, que pode causar um discurso pouco informativo, vazio de conteúdo com pausas secundárias a dificuldade de encontrar palavras, circunlóquios e falta de especificidade; e apresenta a compreensão e a repetição preservadas. Essas dificuldades apresentam-se em diferentes níveis de gravidade, comprometendo a funcionalidade da comunicação (anexo 1).

A avaliação da linguagem dos afásicos deve contemplar aspectos fonético-fonológicos, morfológicos, sintáticos, semânticos e pragmáticos. 0 
discurso permite avaliar todos esses aspectos e, por isso, é fundamental a sua presença como instrumento para avaliação fonoaudiológica.

O discurso é definido como unidade da linguagem acima da sentença, segundo a perspectiva formalista ou estruturalista, e como a linguagem em uso, segundo a perspectiva funcional. A análise do discurso pode ser desenvolvida nos níveis da microestrutura, no qual os aspectos analisados são fonológicos, léxico-semânticos e sintáticos, e da macroestrutura, em que o objeto de análise é o significado global do discurso visando a organização dos significados e o contexto em uma perspectiva social (Armstrong, 2000).

Há vários métodos de elicitação de amostras de discurso em sujeitos afásicos utilizados em pesquisas, tais como descrições de cenas únicas ou em sequência, recontagem de história, narrativa de história culturalmente conhecida como a história da "Cinderela", relatos de experiências biográficas e procedimentos (Nicholas et al., 1985, Nicholas e Brookshire, 1993, Coelho et al., 1994, Saffran et al., 1989, Glosser, Deser 1990). O Banco de Afasia propõe o uso da história Cinderela para elicitação do discurso, porque é uma história familiar na cultura ocidental, fornece dados de fácil reconhecimento por parte do examinador e poupa esforços de resgate mnésicos e executivos de organização do material (MacWhinney et. al, 2010). A Cinderela é frequentemente usada em estudos com afásicos (Faroqi-Shah, Thompson, 2007; Rochon et al., 2000; Stark, Viola, 2007; Stark, 2010; Bird, Franklin, 1996; Thompson et. al, 2012).

Atualmente, busca-se melhorar os instrumentos de análise do discurso, para alcançar rapidez, eficiência e menor risco de erros. Neste sentido, nos últimos anos, tem surgido crescente número de pesquisas relacionadas ao 
processamento automatizado de dados de discurso. Esses estudos têm demonstrado a possibilidade de realizar diagnóstico diferencial e verificar a evolução de doença por meio de análises utilizando tecnologia computadorizada (MacWhinney, 2000; Fergadiotis et al., 2013; Fraser et al., 2014; Toledo et. al, 2014; Cunha, 2015).

Além disso, exames de imagem, tais como tomografia computadorizada, ressonância magnética e tomografia computadorizada por emissão de fóton único (SPECT), são utilizados para auxiliar no diagnóstico diferencial e, também, no último caso, para verificar a eficiência de medicação e terapia fonoaudiológica como medida de evolução do processo de reabilitação (Valotassiou et al., 2014; Sitek et al., 2014; Yamada et al., 2016).

O estudo de discurso auxilia o entendimento sobre como os indivíduos afásicos se comunicam em situações do cotidiano. A diversidade de amostras do discurso fornece aos pesquisadores e clínicos um rico arsenal de análises que rende informações nos diferentes níveis da linguagem envolvidos na construção do discurso. O discurso é multifacetado e pode ser observado por diferentes perspectivas e interfaces dos aspectos micro e macrolinguísticos. As conexões entre os dois níveis permitem conhecer os processos linguísticos implicados na produção do discurso e fornecem caminhos para o tratamento dos dados do discurso (Armstrong, 2000).

A maioria dos estudos sobre a produção de discurso dos afásicos foi feita em línguas anglo-saxônicas e nesses estudos foram priorizadas análises de aspectos fonológicos e semânticos (MacWhinney et al., 2011; Thompson et al., 2012; Rochon et. al., 2000). Poucas investigações tomaram por objeto o discurso. A escassez de investigações pode ser explicada entre outras razões 
pela demanda de tempo para transcrição e pela demora e volume de trabalho na análise, quando se emprega métodos manuais convencionais.

$\mathrm{Na}$ presente pesquisa, tomamos por objeto de estudo o discurso de indivíduos cognitivamente sadios e afásicos, a fim de explorar instrumento computadorizado para avaliação dos aspectos macro e microestruturais, com o objetivo de verificar a sua eficácia como diferenciador inter e intra-grupos. Para isso, foram escolhidos dois tipos de estímulos: a história da Cinderela e a prancha do Roubo dos Biscoitos. A história da Cinderela é utilizada em pesquisas e faz parte do Banco de Afasia (MacWhinney et. al, 2010). O Roubo dos Biscoitos faz parte do Teste de Boston para o Diagnóstico das Afasias (Goodglass, Kaplan, Barresi, 2001). O uso de tecnologia computadorizada tem por objetivo explorar as ferramentas de processamento automatizado de dados a fim de reduzir o tempo de transcrição, tornar a análise menos trabalhosa e com menor número de erros. Utilizamos o SPECT, exame de imagem, para complementar o estudo de instrumento para verificar a evolução da afasia. 


\section{OBJETIVOS}

\section{Objetivo Geral:}

- Verificar se existem diferenças entre os grupos de sujeitos com afasia de Broca, afasia anômica e cognitivamente sadios, na produção de narrativas.

\section{Objetivos Específicos:}

- Analisar, por meio de tecnologias computadorizadas, aspectos macro e microestruturais do discurso de indivíduos cognitivamente sadios, afásicos de Broca e afásicos anômicos.

- Explorar o discurso como indicador de recuperação da afasia.

- Analisar a contribuição do SPECT para verificação de evolução da afasia junto ao discurso.

\section{Hipóteses do trabalho:}

As hipóteses da investigação são as seguintes:

- Haverá diferenças entre os grupos de indivíduos com afasia de Broca, afasia anômica e indivíduos cognitivamente sadios na produção de narrativas.

- As tecnologias computadorizadas permitirão analisar aspectos macro e microestruturais do discurso de indivíduos sadios e com afasia.

- Serão detectados indicadores de recuperação da afasia, tanto comportamentais quanto neurais. 


\section{REVISÃO DE LITERATURA}

\subsection{Acidente Vascular Cerebral e Afasia}

Acidente vascular cerebral (AVC) é o termo utilizado para designar a síndrome de alteração focal transitória ou definitiva de uma área cerebral causada por doença cerebrovascular. O AVC é a segunda maior causa de mortes no mundo e o Brasil apresenta as maiores taxas de mortalidade por AVC (Radanovic, 2015).

O AVC pode ser classificado em isquêmico, quando há obstrução de um vaso sanguíneo, bloqueando o seu fluxo para as células cerebrais, ou hemorrágico, quando há ruptura de um vaso, com consequente sangramento intraparenquimatoso ou subaracnóideo (Radanovic, 2015).

Entre as sequelas decorrentes do AVC, encontra-se a afasia, prejuízo da linguagem que abrange a compreensão e a produção oral e escrita (Hallowell, Chapey, 2008). Desde o século 19, duas síndromes afásicas fundamentais têm sido estabelecidas: afasias de Wernicke e de Broca. Essas síndromes relacionam-se a duas operações linguísticas básicas: seleção e sequenciação (Ardila, 2014).

A taxonomia das afasias, porém, é mais abrangente e admite outros subtipos de afasias: anômica, transcorticais sensorial e motora, mistas e globais e ainda quadros que não se incluem em qualquer classificação (Berthier el al, 2011; Duffy, 2013). A anomia está presente em todos os quadros afásicos, porém na afasia anômica ela é o sintoma proeminente e característico (Ardila, 2014).

Os critérios utilizados para classificar as afasias são a fluência, a compreensão auditiva e a repetição (Ardila, 2014; Berthier el al, 2011). 
Nesta revisão, destacaremos os quadros de interesse para a investigação sobre narrativas na afasia: afasia de Broca e afasia anômica.

A afasia de Broca está classificada entre os quadros não fluentes. A descrição sindrômica deste tipo de afasia inclui: compreensão funcional (exceto para elementos sintáticos complexos) e alteração na repetição e nomeação. Em casos graves pode ocorrer mutismo inicial ou emissões limitadas e estereotipias. Em casos menos graves, a linguagem espontânea é pouco fluente, com prejuízo sintático, em estilo telegráfico, limitada a substantivos (de alta frequência e imageabilidade), escassos verbos e presença de parafasias fonêmicas. As emissões são produzidas com grande esforço, podendo ocorrer alterações de articulação (disartria) (Duffy, 2013) e dificuldade na programação de fala (apraxia de fala) (Duffy, 2013). Pausas prolongadas e preenchimentos mostram a dificuldade para acessar as palavras.

A afasia anômica é caracterizada por dificuldade em encontrar palavras durante a enunciação e denominar objetos, que pode causar um discurso pouco informativo, com pausas secundárias à dificuldade de encontrar palavras, circunlóquios e falta de especificidade. A compreensão e a repetição estão preservadas.

Estes dois tipos de afasia foram os escolhidos para o presente estudo pelos seguintes motivos: são as afasias mais prevalentes no hospital escola; esses afásicos apresentam compreensão oral adequada, o que facilita 0 entendimento e aplicação dos testes; e pela possibilidade de de comparar ambos os grupos no que diz respeito, principalmente, dificuldades no emprego de substantivos, que ocorre principalmente no grupo de afásicos anômicos, e emprego de verbos, mais esperada no grupo de afásicos de Broca. 


\subsection{Discurso}

\subsubsection{Avaliação de linguagem de afásicos: discurso}

A avaliação do afásico inclui a observação de aspectos da linguagem, preservados e alterados pelo AVC, entre eles o discurso. O discurso constitui uma interessante perspectiva de análise da linguagem, pois permite a observação dos vários componentes linguísticos (fonético, fonológico, morfológico e sintático) e paralinguísticos, assim como a interação da linguagem com outros aspectos cognitivos como atenção, memória operacional e de longa duração, função executiva, entre outros. Deste modo, a avaliação do discurso tem sido considerada como discriminativa e essencial nas avaliações fonoaudiológicas.

Os afásicos podem apresentar problemas no discurso, consequentes a dificuldades que ocorrem no nível das proposições (anomias, parafasias, problemas de sintaxe). Indiretamente, a organização global do discurso e os aspectos pragmáticos sofrem as consequências dos desvios da microestrutura (Mansur, Radanovic, 2004).

Segundo a literatura, os afásicos não fluentes utilizam maior número de substantivos do que de verbos, menor número de palavras de classe fechada, menor número de pronomes do que o esperado e apresentem omissões frequentes de determinantes em seus discursos (Armstrong, 2000). Por outro lado, em afásicos fluentes, como no caso, dos anômicos, é consenso que utilizem maior número de verbos do que de substantivos em seus discursos.

Em outros estudos, comparando afásicos não fluentes e indivíduos normais, encontramos que as habilidades sintáticas do discurso foram exploradas em termos de complexidade gramatical das sentenças, erros sintáticos e, mais 
recentemente, estrutura de argumento do verbo (Saffran et al., 1989, Goodglass et al. 1993, Schwartz et al., 1994, Bird, Franklin, 1996). Nesses estudos, os afásicos não fluentes apresentaram construções gramaticais menos complexas do que indivíduos normais, verbos com as estruturas de argumento mais simples e uma variedade de omissões de elementos gramaticais.

Esses problemas trazem aos afásicos comprometimento nas suas relações interpessoais. Isso porque as alterações de linguagem dificultam a produção e/ou a interpretação verbal e, consequentemente, afetam a comunicação com outras pessoas, prejudicando, assim, a interação com familiares e o convívio social (Chun, 2010).

\subsubsection{Definição de discurso: microestrutura e macroestrutura}

O discurso pode ser definido de acordo com diferentes perspectivas teóricas. Segundo a perspectiva formalista ou estruturalista, é uma unidade da linguagem acima da sentença e, segundo a perspectiva funcional, o discurso é a linguagem em uso (Armstrong, 2000).

A teoria de Kintsch, van Dick (1978) prevê a análise do discurso nos níveis micro e macroestruturais. Na microestrutura, os aspectos analisados são fonológicos, morfológicos, léxico-semânticos e sintáticos. Na macroestrutura, analisa-se o significado global do discurso, a organização do significado, o contexto e o objetivo do texto em uma perspectiva social. Esta teoria é adotada por vários estudiosos (Brandão, 2005; Lira, 2014) e representa a visão dominante sobre os processos discursivos (Cosentino et al., 2013). Optamos por nortear nosso estudo nessa teoria. 
Para Mross (1990), a microestrutura é aquela parte da representação que contém a informação local correspondente às palavras individuais e suas relações no texto. A coesão é baseada na sobreposição do argumento (coreferência). Em outras palavras, as referências formam uma trama interrelacionada. Cada proposição em um texto deve compartilhar argumento(s) com pelo menos outra proposição. Isto é necessário, mas não é uma condição suficiente da coerência.

$\mathrm{Na}$ linguagem falada, a informação linguística é basicamente realizada pelas palavras e por sua organização na sentença. Todavia, os sons da fala não são constituídos apenas por elementos segmentais, mas também por elementos não segmentais que na cadeia sonora contribuem para a efetivação da fala (Bulhões, 2006).

A prosódia pode sinalizar informações em dois canais - um linguístico e um paralinguístico. O primeiro é responsável pela expressão de mensagens usando os signos convencionais da linguagem e o segundo, pela informação extra, aquela que leva o ouvinte a obter conhecimento sobre a personalidade e as intenções do falante num determinado contexto discursivo (Bulhões, 2006).

Os fenômenos paralinguísticos incluem uma série de recursos prosódicos, tais como, intensidade, entoação, velocidade de fala, ritmo, duração e outros, nos quais estão implícitos eventos da linguagem falada, como pausas, sons onomatopaicos, interjeições, timbre vocal, e outras emissões vocais não lexicalizadas produzidas pelo aparelho fonador. Cada uma dessas propriedades contribui para a fluência da fala, propiciando realce semântico ao significado de uma mensagem articulada (Bulhões, 2006). 
Em relação à macroestrutura, duas teorias buscam explicar como o macroprocessamento ocorre. Uma delas defende a ideia da generalização e sumarização dos conteúdos das microproposições (Johnson-Laird, 1983); a outra advoga que o conhecimento de mundo e o raciocínio pragmático têm papel crucial no macroprocessamento do discurso (Johnson-Laird, 1983; van Dijk, 2011).

\subsubsection{Técnicas de elicitação e gêneros discursivos}

A escolha de métodos de amostras de discurso é importante para auxiliar no tipo de análise do discurso dos afásicos.

$\mathrm{Na}$ literatura da área de Neuropsicologia, frequentemente estuda-se o discurso por meio de pranchas temáticas, figurativas, em cenas únicas ou em sequência ( Nicholas et al., 1985, Nicholas, Brookshire, 1993, Coelho et al., 1994, Saffran et al., 1989), conversação (ref) e relatos de experiências biográficas (Ulatowska Glosser e Deser 1990; Vermeulen et al., 1989) e procedimentos (Ulatowska et al., 1983, Williams et al., 1994).

Essas diferentes formas de elicitação induzem gêneros discursivos distintos. Podemos citar como tipos de discurso: narrativo, conversacional, descritivo, procedimental, argumentativo e expositivo. O gênero narrativo é o mais usado na pesquisa com afásicos.

O estudo de Pacheco e Pinto, 2010, apontou para as características linguísticas presentes nas narrativas de um sujeito afásico fluente. Os dados indicaram que a dificuldade principal do sujeito diz respeito à seleção dos elementos linguísticos, sobretudo lexical, o que o levou a produzir muitas pausas para iniciar os enunciados, o que acarretou certa desorganização 
sintática. Apesar das dificuldades, o sujeito apresentou todas as características próprias do gênero narrativo, sempre construído de forma dialógica.

Segundo van Dijk (1977, 1980), o discurso narrativo possui estrutura esquemática caracterizada por cenário, problema e resolução que pode ocorrer em diversas modalidades, como reconto e produção de histórias, a partir de entrevista semi-dirigida, emissão espontânea ou pranchas figurativas (Davis et al., 1997; Ska et al., 2004).

A utilização de figuras é uma ferramenta válida e eficiente para elicitar o discurso, por se aproximar da conversação natural (Duong et al., 2003). Segundo Duong, Ska, 2001, são propostos na literatura dois tipos de estímulos de figuras para elicitar o discurso: cena única e cenas em sequência.

O uso da cena única pode induzir a descrição de eventos que não necessariamente formam uma história (Ska, Joanette, 1996; Davis et al., 1997; Duong, Ska, 2001), ou seja, pode provocar a descrição de uma situação estática ao invés de uma narrativa, que normalmente envolve alguma orientação, ação para resolução de um problema e o desfecho (Armstrong, 2000). Já o uso de cenas em sequência requer mais habilidades cognitivas, como processamento visual e memória de trabalho, porém facilita 0 processamento necessário para estruturar uma narrativa (Ska, Joanette, 1996; Davis et al., 1997; Duong, Ska, 2001).

A prancha representando o Roubo dos Biscoitos é um exemplo de elicitação de discurso por meio de cena única. É utilizada em diversos estudos com indivíduos com alterações neurológicas que apresentam alteração de fala e linguagem, principalmente com indivíduos afásicos, a fim de avaliar a fala semiespontânea e de acompanhamento da evolução da terapia (Conroy eta al., 
2009; Medina et al., 2012; Agis et al., 2016; Stark, Warburton, 2018; Hernández-Domínguez, 2018; Vuksanović, 2018). Trata-se de uma cena em contexto familiar, que apresenta uma situação problema. Entre as vantagens, o emprego dessa cena gera material suficiente para análise do discurso. Podese reconhecer que é a cena única mais utilizada em contextos clínicos e de pesquisa. Por este motivo, essa prancha foi escolhida como parâmetro de comparação à história da Cinderela na presente pesquisa.

Medeiros et al, 2016, compararam os discursos narrativo, descritivo, conversacional e procedural entre indivíduos afásicos fluentes e indivíduos cognitivamente sadios e verificaram que houve diferenças estatisticamente significantes na maioria das variáveis investigadas em todos os tipos de discursos tanto na análise quantitativa quanto na qualitativa. Concluíram, portanto, que os indivíduos afásicos apresentaram maior facilidade no discurso narrativo e maior dificuldade nos demais discursos, porém comparando-os aos indivíduos cognitivamente sadios apresentaram maior dificuldade em todos os gêneros discursivos orais. Uma das formas de elicitação utilizada neste estudo foi a cena única.

A história da Cinderela é, por outro lado, um exemplo de elicitação de discurso por meio de uso de cenas em sequência. O Banco de Afasia (Aphasia Bank), que compartilha interações multimídia de amostras uniformes de discursos de indivíduos normais e afásicos a fim de estudar a comunicação na afasia, propõe o uso de histórias infantis com apoio em figuras, para análises de discurso (MacWhinney et al, 2011). A história da "Cinderela" foi incluída no banco, por ser uma história familiar na cultura ocidental e por gerar em pouco tempo, material de extensão suficiente para a análise (MacWhinney et al, 
2010). É uma história prototípica que fornece dados de fácil reconhecimento por parte do examinador, além da possibilidade de análise de macroestrutura, presta-se ao exame de microestrutura por poupar esforços de resgate mnésicos e executivos de organização do material (MacWhinney et al, 2010). Essas razões tornam frequente o uso da "Cinderela" em estudos com afásicos (Faroqi-Shah, Thompson, 2007; Rochon et al, 2000; Stark, Viola, 2007; Thompson et al, 1997; Stark, 2013; Bird, Franklin, 1996; Thompson et. al, 2012; Fergadiotis et al., 2013).

Essa história foi utilizada no estudo de Bird e Franklin (1996), no qual analisou-se 12 categorias no discurso de cinco afásicos (palavras por minuto, proporção de palavras de classe fechada, índice de determinante, relação substantivo / pronome, relação substantivo / verbo, índice de inflexão, complexidade do auxiliar, proporção de sentenças bem formadas, tamanho da sentença, proporção de palavras dentro da sentença, índice de elaboração, índice de incorporação). No estudo, participaram dois sujeitos afásicos fluentes e três sujeitos afásicos não fluentes. Concluiu-se que as diferenças entre a enunciação dos afásicos fluentes e não fluentes foram motivadas apenas pelas diferenças nas medidas de complexidade sintática e de estruturação gramatical. A produção de sentenças dos afásicos fluentes e não fluentes não se distinguiu, exceto com relação à fluência, considerada pela taxa de elocução.

Outro estudo que também utilizou a história da Cinderela foi o de Rochon et al (2000) para analisar as características morfológicas e estruturais da produção de fala de 29 sujeitos com afasia de Broca e 12 normais. Os autores concluíram que os sujeitos não fluentes diferem dos normais na elaboração 
estrutural das sentenças, bem como na velocidade de enunciação, e que os sujeitos afásicos agramáticos podem diferir dos fluentes, na produção de morfemas gramaticais livres e acoplados.

O estudo de Fergadiotis et al. (2013) avaliou quatro medidas de diversidade lexical, que é um aspecto da microestrutura, também por meio da análise do discurso da "Cinderela". Concluíram que duas medidas são as melhores para a análise da diversidade lexical: Medida da Diversidade Lexical Textual e Taxa Média do Número Total de Palavras em Amostras.

Silveira, Mansur (2014) exploraram narrativas infantis, como "Cinderela", "Chapeuzinho Vermelho" e "A Branca de Neve e os Sete Anões", com o objetivo de selecionar a história mais popular entre os sujeitos falantes do Português Brasileiro. Ao analisar aspectos macroestruturais concluíram que as três histórias apresentaram número similar de proposições, o que sinaliza sua equivalência como instrumento de coleta de dados para análise de discurso de falantes do Português Brasileiro. A narrativa gerou material para análise de macroestrutura o que diferenciou indivíduos afásicos e cognitivamente sadios. Foi possível explorar ferramentas computadorizadas para a análise de discurso em contexto clínico.

Nota-se, nesses estudos, que as amostras da história da Cinderela trouxeram elementos suficientes para a análise de alterações de linguagem e que a história do Chapeuzinho Vermelho, embora popular apresentava muitas versões o que dificultaria a comparação entre sujeitos.

\subsection{Análise computadorizada e discurso}

As transcrições e análises manuais são demoradas e passíveis de erros, o que dificulta a sua aplicabilidade clínica. Podemos citar como estudos que 
utilizaram as análises manuais, os de Mackenzie (2000), Marini et al. (2005), Forbes-McKay, Veneri (2005), Lira (2014) e Silveira, Mansur (2014). Tecnologias computadorizadas que descreveremos a seguir, surgem como recurso para auxiliar o processo de transcrição e análise e a organização da base de dados.

O banco de dados Child Language Data Exchange System (CHILDES) (MacWhinney, 2000), que armazena material referente à aquisição e desenvolvimento de linguagem de crianças, foi um dos pioneiros e inspirador para a construção de banco de dados voltados para adultos.

O Linguistic Data Consortium (LDC) é um banco de textos, léxico e fala de adultossendo um dos pioneiros neste campo (Liberman, Bird,1992).

O Banco de Afasia (Aphasia Bank) amostras uniformes de discursos de indivíduos normais e compartilha dados de interações multimídia de e afásicos a fim de estudar a comunicação. Propõe o uso de histórias infantis com apoio em figuras, como a Cinderela, para análises de discurso (MacWhinney et al, 2011). O banco utiliza o programa CLAN (Computerized Language Analysis) (MacWhinney, 2000), que permite a análise de uma grande variedade de estruturas linguísticas: discursivas, dados lexicais, morfossintáticos, fonológicos e gestuais (MacWhinney et al., 2010).

Peintner et al. (2008) utilizou análises automáticas da fala de sujeitos com demência frontotemporal (DFT) e normais, sendo extraídas diversas características fonológicas, morfossintáticas e semânticas que diferenciaram ambos os grupos. Outro estudo, já citado, de Fergadiotis et al. (2011), utilizou para a análise do discurso de sujeitos adultos e idosos o software voc-D4 para estimar a diversidade lexical. 
O estudo de Fraser et al. (2014) empregou análise computacional para extrair características lexicais e sintáticas da narrativa produzida por indivíduos com demência semântica, afasia progressiva primária e controles sadios, o que permitiu a diferenciação entre esses grupos.

A ferramenta Coh-Metrix-Port foi adaptada para o português por pesquisadores do Núcleo interinstitucional de Linguística Computacional (NILC) do Instituto de Ciências Matemáticas e de Computação da Universidade de São Paulo, criado em 1993 para fomentar projetos de pesquisa e desenvolvimento em Linguística Computacional e Processamento de Linguagem Natural (PLN) (Scarton e Aluísio, 2010). Apresenta 48 métricas para análise de características lexicais e sintáticas. São elas: índice flesch (Martins et al., 1996); informações do texto e palavras que consistem em contagens básicas (número de palavras, parágrafos, número de verbos, entre outros), frequências (frequência de palavras de conteúdo) e hiperônimos; informações sintáticas que consistem em constituintes (incidência de sintagmas nominais, palavras antes de verbos, etc), conectivos (incidência de todos os conectivos), pronomes, tipos e tokens; operadores lógicos (incidência de operadores lógicos, numero de $e$, entre outros) (Scarton et al., 2010).

O Coh-Metrix-Dementia foi uma ferramenta criada para a população de portadores de quadros demenciais. Foi desenvolvido no NILC e adiciona novas métricas as 48 existentes no Coh-Metrix-Port. As novas métricas do Cohmetrix-Dementia incluem a análise de semântica latente, medidas de diversidade lexical, complexidade sintática e densidade semântica (Toledo et al., 2014; Cunha, 2015). Essa ferramenta mostrou a possibilidade de diferenciação entre indivíduos cognitivamente sadios, com comprometimento 
cognitivo leve e com doença de Alzheimer, com base na análise computadorizada das amostras de discurso da história da Cinderela.

\subsection{SPECT}

A tomografia computadorizada por emissão de fóton único (SPECT) é utilizada para verificar o fluxo sanguíneo cerebral após lesão neurológica. Consiste em injetar na veia do sujeito um produto que se concentra dentro das células do sistema nervoso e, desta forma, é capaz de mostrar o metabolismo cerebral. Os riscos são mínimos, relacionados apenas à probabilidade de reação adversa a medicamentos (incluindo reação alérgica). Não existe dano ou risco para o sujeito nas doses de radiação habitualmente utilizada nos procedimentos diagnósticos de medicina nuclear. A contraindicação é a realização em gestantes e mulheres que estejam amamentando. Esse tipo de exame tem sido utilizado na prática clínica e em pesquisas com a finalidade de estabelecer diagnóstico diferencial e também verificar a evolução da doença.

Valotassiou et al. (2014) utilizou o SPECT para diferenciar as variantes da demência frontotemporal em um total de 91 sujeitos. O SPECT foi sensível para o diagnóstico diferencial.

Na mesma direção, Sitek et al., 2014, tiveram como objetivo diferenciar as variantes da afasia progressiva primária (não fluente, semântica e logopênica) por meio da utilização de SPECT comparado a outros exames de imagem. Concluiu-se que o diagnóstico das variantes da afasia progressiva primária é mais viável com a análise quantitativa de imagens de SPECT do que com a análise visual puramente qualitativa da ressonância magnética. As anormalidades de hipoperfusão evidenciadas pelo SPECT são mais específicas das variantes do que os padrões de atrofia. 
Já no estudo de Yamada et al (2016), o SPECT foi utilizado após duas semanas para verificar a evolução do paciente afásico antes e após terapia fonoaudiológica e com uso do medicamento atomoxetina. O SPECT foi capaz de mostrar evolução na funcionalidade cerebral dos pacientes, concluindo que aqueles que aderiram à terapia e ao medicamento tiveram benefícios.

Em resumo, esses estudos apontam que o SPECT foi sensível para verificar locais da lesão e a funcionalidade cerebral e serviu como um instrumento para avaliação e acompanhamento da doença. 


\section{MÉTODO}

\subsection{Preceitos Éticos}

Este estudo foi aprovado pela Comissão de Ética para Análise de Projetos de Pesquisa do Hospital das Clínicas da Faculdade de Medicina da Universidade de São Paulo (protocolo 1.955.648) (Anexo A).

Todos os sujeitos incluídos nessa pesquisa assinaram o Termo de Consentimento Livre e Esclarecido - (TCLE) (Anexo B), elaborado segundo normas do desenvolvimento de pesquisas com seres humanos (CNS 196/96).

\subsection{Sujeitos}

A amostra deste estudo foi constituída por 53 indivíduos divididos em 3 grupos: Grupo Afásicos 1 (GA1), constituído por 8 indivíduos com afasia de Broca e afasia anômica decorrente de lesão vascular e acompanhados para o estudo longitudinal, Grupo Afásicos 2 (GA2), constituído por outros 15 indivíduos com afasia de Broca e afasia anômica decorrentes de lesão vascular, e Grupo controle (GC), composto por 30 sujeitos sadios do ponto de vista cognitivo. Cada grupo foi formado por sujeitos que tinham o português brasileiro como primeira língua, com idade entre 35 e 95, escolaridade igual ou superior a 4 anos.

Os sujeitos do GA1 e do GA2 são provenientes do pronto-socorro e do Ambulatório de Linguagem do Hospital das Clínicas da Faculdade de Medicina da Universidade de São Paulo (HCFMUSP). Todos os pacientes incluídos no estudo tiveram diagnóstico confirmado pela equipe de neurologia da FMUSP. 
Os sujeitos do GC foram recrutados aleatoriamente entre voluntários da comunidade.

\subsubsection{Critérios de inclusão e exclusão}

Os critérios de inclusão para o GC foram: idade igual ou superior a 18 anos, escolaridade igual ou superior a quatro anos, dominância manual direita, língua portuguesa materna, ausência de quadro demencial, de co-morbidades não controladas e de alterações comportamentais, psiquiátricas e de distúrbios neurológicos. O GC foi submetido a avaliações de rastreio para verificação de critérios de normalidade: Mini Exame do Estado Mental (MEEM) (Folstein et al., 1975) (Anexo C); Fluência Verbal - critério semântico (animais) (Brucki, Rocha, 2004) e fonêmica (Machado et al, 2009) (Anexo D) e critérios do Mayo Older American Normative Studies (MOANS) (Smith, 2003) (Anexo E). Os voluntários deveriam apresentar desempenho aceitável para a escolaridade e cumprir todos os requisitos destas avaliações para ser incluído no estudo. Foram excluídos do estudo os voluntários com redução da acuidade auditiva e visual incompatíveis com a funcionalidade e com o desempenho da tarefa alvo e com desconhecimento da história a ser narrada para a presente pesquisa.

Para ambos os grupos de afásicos (GA1 e GA2), os critérios de inclusão foram: idade igual ou superior a 18 anos, escolaridade igual ou superior a quatro anos, dominância manual direita, língua portuguesa materna, internação no HCFMUSP, frequência ao Ambulatório de Linguagem da Divisão de Fonoaudiologia do HCFMUSP, ausência de quadro demencial e de comorbidades não controladas, ausência de alterações comportamentais, psiquiátricas e de distúrbios neurológicos, com exceção do acidente vascular cerebral único em hemisfério esquerdo, causa da afasia, escore de gravidade 
da afasia (severity rating and profile of speech characteristics) acima de dois (Goodglass et al, 2001) (Anexo F) e inteligibilidade acima de cinco (Duffy, 2013) (ANEXO G). Essas medidas de gravidade e de inteligibilidade expressavam a capacidade de enunciação em pacientes que apresentassem traços de apraxia de fala e disartria. Todos os sujeitos foram avaliados pelo Teste de Boston para Diagnóstico da Afasia (Boston Diagnostic Aphasia Examination) (Goodglass et al 2001) (Anexo H) e foram incluídos aqueles com afasia de Broca e afasia anômica.

Foram excluídos do estudo os afásicos com redução da acuidade auditiva e visual incompatíveis com a funcionalidade e com o desempenho da tarefa alvo e com desconhecimento da história a ser narrada para a presente pesquisa.

Os indivíduos do GA1 que não realizaram as três etapas de coleta de amostra de dados nos tempos determinados (até um mês após AVC, três meses após $A V C$ e seis meses após $A V C$ ) e que não compareceram à avaliação neurológica ou que não realizaram o SPECT foram excluídos do estudo. Além disso, participantes gestantes e em fase de amamentação; e participantes que tivessem alergia ao radiofármaco ECD-99mTc (dímero etilcisteinato marcado com tecnécio) utilizado no SPECT também foram excluídos do estudo.

Não foram excluídos indivíduos que estavam em programas de reabilitação fonoaudiológica, pois nosso objetivo é a análise de medidas de evolução e não a reabilitação fonoaudiológica em si. 


\subsection{Material}

\begin{tabular}{|l|l|}
\hline \multicolumn{1}{|c|}{ Testes } & \multicolumn{1}{|c|}{ Procedimentos solicitados ao sujeito } \\
\hline Teste de Fluência Verbal Fonêmica (letras F, A, S) & $\begin{array}{l}\text { Falar todas as palavras iniciadas com as letras /F/, } \\
\text { IA/ e /S/ que recordasse durante um minuto, sendo } \\
\text { excluídos nomes próprios ou palavras derivadas. A } \\
\text { emissão das palavras com cada letra foi feita } \\
\text { separadamente (Anexo D). }\end{array}$ \\
\hline Teste de Fluência Verbal Semântica (animais) & $\begin{array}{l}\text { Evocar nomes de animais durante um minuto } \\
\text { (Anexo D). }\end{array}$ \\
\hline Mini Exame do Estado Mental & $\begin{array}{l}\text { Realização de tarefas de vários domínios } \\
\text { (atençâ, memória imediata e de evocação, } \\
\text { linguagem - repetição, compreensão, cópia de } \\
\text { desenho, escrita, orientação espacial e temporal, } \\
\text { como forma de rastreamento cognitivo) (Anexo C). }\end{array}$ \\
\hline Critérios do MOANS & $\begin{array}{l}\text { Questionamento sobre critérios definidores de } \\
\text { presumível ausência de comprometimento } \\
\text { neuropsicológico (Anexo E). }\end{array}$ \\
\hline Teste de Boston para Diagnóstico da Afasia \\
(Boston Diagnostic Aphasia Examination) & $\begin{array}{l}\text { O indivíduo realizou tarefas de compreensão e } \\
\text { expressão de linguagem oral e escrita a fim de } \\
\text { diagnosticar a presença e o tipo de afasia (Anexo } \\
\text { H). }\end{array}$ \\
\hline Narração a partir de cena única & $\begin{array}{l}\text { Produção de narrativa - prancha figurativa Roubo } \\
\text { dos Biscoitos (Anexo I). }\end{array}$ \\
\hline Narração a partir de cenas em sequência & $\begin{array}{l}\text { Produção de narrativa - sequência de 22 cenas, } \\
\text { sem legendas, em preto e branco, da história da } \\
\text { Cinderela (Anexo J). }\end{array}$ \\
\hline
\end{tabular}

Todas as provas foram gravadas e as narrativas foram transcritas.

Para auxílio à transcrição, foi utilizado o software Express Scribe (http://www.nch.com.au/scribe/) e para a análise dos dados foram utilizados outros programas desenvolvidos pela equipe do NILC - Núcleo Interinstitucional de Linguística Computacional da USP de São Carlos que serão descritos posteriormente.

\subsection{Procedimentos}

As avaliações foram realizadas individualmente pela mesma avaliadora. Inicialmente, foram aplicados os testes em acordo com os critérios de inclusão 
e exclusão para todos os sujeitos. Após a seleção foi realizada a avaliação do discurso dos sujeitos.

Para a constituição do GA1, foram triados pacientes com diagnóstico de AVC que deram entrada no pronto-socorro do HCFMUSP com pedido de avaliação fonoaudiológica no período entre março de 2016 a julho de 2017. Já para a constituição do GA2, foram selecionados pacientes com diagnóstico de AVC que foram avaliados no Ambulatório de Linguagem do HCFMUSP, independente do tempo de lesão. Foram escolhidos aqueles que seguiam os critérios de inclusão e exclusão.

Os sujeitos do GC e do GA2 realizaram a avaliação do discurso por meio da história da Cinderela em um único momento. Já os sujeitos do GA1 realizaram a avaliação do discurso por meio da prancha figurativa Roubo dos Biscoitos e da história da Cinderela em três momentos, um mês após o AVC, três meses após o AVC e seis meses após o AVC. Além disso, os sujeitos do GA1 foram avaliados do ponto de vista neurológico, na Divisão de Clínica Neurológica do HCFMUSP. Além da avaliação clínica, realizaram tomografia computadorizada por emissão de fóton único (SPECT) (Figura 1). 
Figura 1: fluxograma dos procedimentos do G1

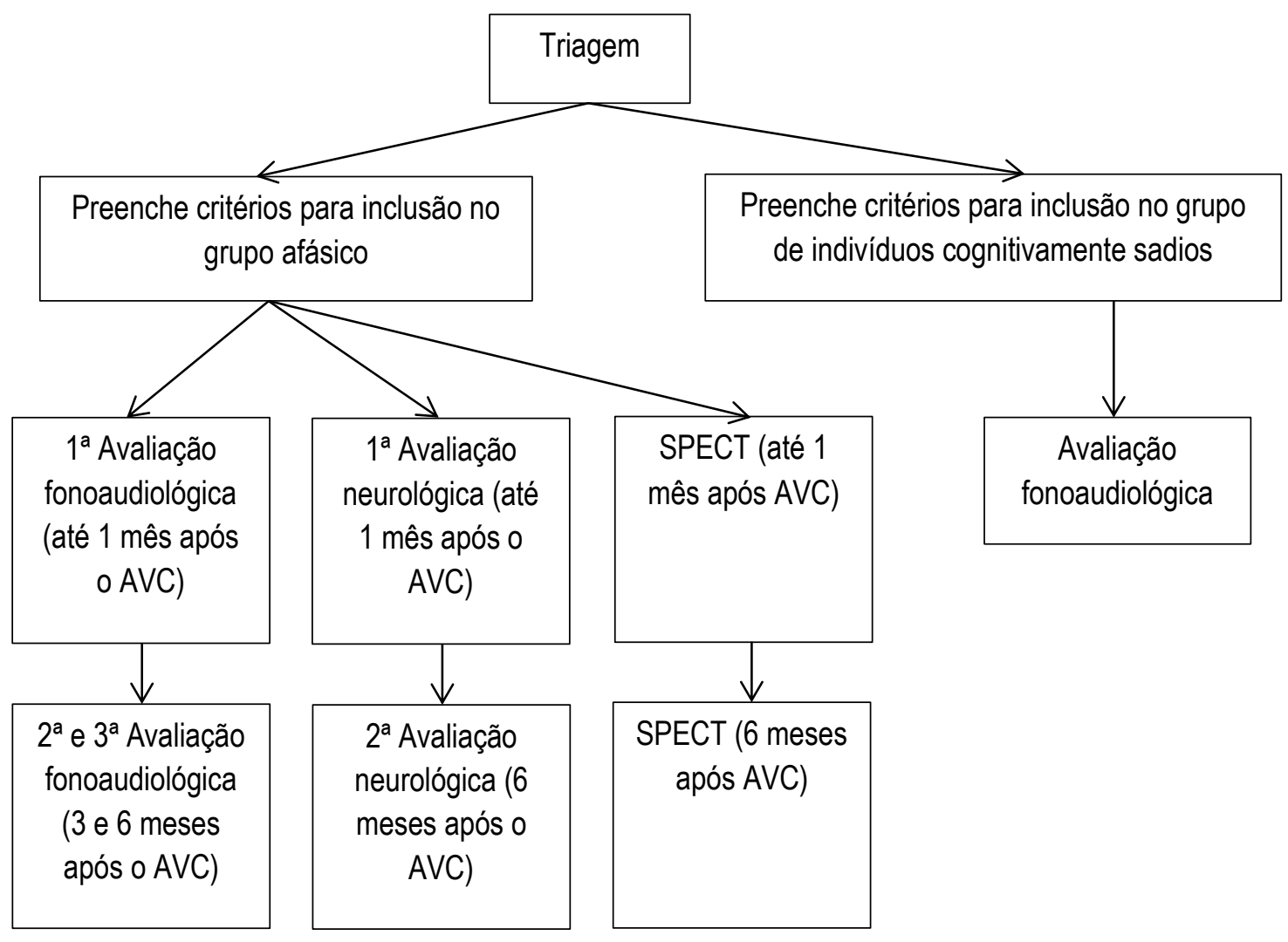

A sequência de procedimentos para coleta de dados da história da Cinderela para todos os grupos foi a seguinte: primeiramente, os participantes foram questionados pelo examinador se conheciam e se recordavam da história da Cinderela. Em seguida, foram instruídos a folhear o livro contendo a sequência de 22 cenas que retratavam a história da Cinderela. O livro permaneceu na frente do sujeito durante toda a avaliação permitindo que ele o utilizasse durante a narrativa. Foi solicitado ao indivíduo que narrasse a história com suas próprias palavras como se estivesse contando para alguém que não a conhecesse. Não houve tempo limite estabelecido para os participantes contarem a história. $\mathrm{O}$ examinador não fez nenhum comentário enquanto 0 participante narrava, a não ser se houvesse dificuldade de iniciar ou continuar a história, ou em situações de pausas longas (maiores do que cinco segundos). 
Neste caso, o examinador interviu com questões do tipo "O que aconteceu depois?" para encorajar o participante a continuar a sua narrativa. Quando o sujeito não conseguiu prosseguir foi questionado se ele havia finalizado a história e se tinha algo a acrescentar.

Para a coleta de amostras do discurso da prancha Roubo dos Biscoitos para o GA1, a prancha foi apresentada ao sujeito, com a solicitação: "descreva tudo o que está acontecendo nesta figura".

A emissão oral foi gravada em áudio e/ou vídeo e o software Express Scribe foi utilizado para agilizar o processo de transcrição manual que seguiu os princípios do NURC / SP No. 338 EF e 331 D2 (Anexo K).

\subsection{Análise dos dados}

A análise do discurso foi realizada nos níveis da microestrutura e da macroestrutura, nos dois estudos realizados.

No estudo 1 comparou-se o GC X GA2 em termos de microestrutura e macroestrutura da história Cinderela e verificou-se se havia diferença entre os sujeitos afásicos de Broca e anômicos.

No estudo 2 analisou-se a micro e macroestrutura do GA1, das narrativas da prancha Roubo dos Biscoitos e da história da Cinderela em três momentos (até um mês, 3 meses e 6 meses após o AVC) a fim de verificar evolução da linguagem e diferenças intra-grupo de afásicos.

\subsubsection{Análise da microestrutura}

Para a análise da microestrutura, um conjunto de métricas foi selecionado em consenso dos pesquisadores, a partir da literatura sobre alterações de linguagem nas afasias (Goodglass et al., 2001, Berthier, 2010, Berthier, 2011) e implementado pela equipe do Núcleo Interinstitucional de 
Linguística Computacional (NILC) da USP de São Carlos, sob a coordenação da Profa Sandra Maria Aluísio.

Para a transcrição da fala foi utilizado o software Express Scribe (http://www.nch.com.au/scribe/). Após a transcrição, todas as amostras de discurso, incluindo as narrativas da Cinderela e da prancha Roubo dos Biscoitos, foram submetidas à análise por meio de 15 métricas.

Para calcular as métricas foram utilizados os seguintes recursos: (1) o tokenizador da NLTK (Natural Language Toolkit) (https://www.nltk.org/), com a finalidade de dividir o texto em palavras; (2) etiquetador morfosintáctico (Pos Tagger), nesse caso foi utilizado um PoS probabilístico que identifica a classe gramatical mais frequente de uma dada palavra (https://link.springer.com/chapter/10.1007\%2F978-3-319-18111-0_18), e

Dicionário de Palavras Simples Flexionadas para o Português Brasileiro (http://www.nilc.icmc.usp.br/nilc/projects/unitex-pb/web/dicionarios.html). Estas métricas foram calculadas via Procedimentos de Seleção e Implementação de um Conjunto de Métricas da área de Processamento de Línguas Naturais (PLN) para textos transcritos.

A seguir serão descritas as 15 métricas utilizadas no estudo.

\begin{tabular}{|l|l|l|}
\hline Métrica & Descrição & $\begin{array}{l}\text { Justificativa da escolha: } \\
\text { análise dos níveis } \\
\text { linguísticos }\end{array}$ \\
\hline $\begin{array}{l}\text { Índice de palavras ausentes no } \\
\text { dicionário }\end{array}$ & $\begin{array}{l}\text { Quantidade de palavras do texto que } \\
\text { não estão presentes em / quantidade } \\
\text { de palavras do texto X 1000. Recursos } \\
\text { de PLN utilizados durante o cálculo: } \\
\text { tokenizador e Dicionário de Palavras } \\
\text { Simples Flexionadas para o Português } \\
\text { Brasileiro. }\end{array}$ & $\begin{array}{l}\text { Análise de aspectos léxico- } \\
\text { semânticos do discurso. }\end{array}$ \\
\hline $\begin{array}{l}\text { Índice de leiturabilidade de } \\
\text { Flesch a correlação entre tamanhos médios } \\
\text { de palavras e sentenças. É utilizada a } \\
\text { fórmula 248.835 - [1.015 x (média de } \\
\text { palavras por sentença)] - [84.6 x } \\
\text { (Número de sílabas do texto / Número }\end{array}$ & $\begin{array}{l}\text { Análise de aspectos sintáticos } \\
\text { do discurso. }\end{array}$ \\
\hline
\end{tabular}




\begin{tabular}{|c|c|c|}
\hline & $\begin{array}{l}\text { de palavras do texto)]. Recursos de } \\
\text { PLN utilizados durante o cálculo: } \\
\text { tokenizador. }\end{array}$ & \\
\hline Quantidade de palavras & $\begin{array}{l}\text { Contam-se todos os tokens do texto e } \\
\text { descontam-se as pontuações. } \\
\text { Recursos de PLN utilizados durante o } \\
\text { cálculo: tokenizador e POS tagger } \\
\text { para identificar pontuações. }\end{array}$ & $\begin{array}{l}\text { Análise de aspectos léxico- } \\
\text { semânticos do discurso. }\end{array}$ \\
\hline $\begin{array}{l}\text { Sílabas por palavra de } \\
\text { conteúdo }\end{array}$ & $\begin{array}{l}\text { Quantidade de sílabas / número de } \\
\text { palavras de conteúdo (substantivos, } \\
\text { verbos, adjetivos e advérbios) no } \\
\text { texto. Quanto maior o número de } \\
\text { sílabas por palavras, maior a } \\
\text { complexidade textual. Recursos de } \\
\text { PLN utilizados durante o cálculo: } \\
\text { tokenizador e POS tagger para } \\
\text { identificar as palavras de conteúdo } \\
\text { (substantivos, verbos, adjetivos e } \\
\text { advérbios). }\end{array}$ & $\begin{array}{l}\text { Análise de aspectos léxico- } \\
\text { semânticos do discurso. }\end{array}$ \\
\hline Incidência de verbos & $\begin{array}{l}\text { É a incidência de verbos em um texto. } \\
\text { Quantidade de verbos / quantidade de } \\
\text { palavras X } 1000 \text {. Recursos de PLN } \\
\text { utilizados durante o cálculo: } \\
\text { tokenizador e POS tagger para } \\
\text { identificar os verbos. }\end{array}$ & $\begin{array}{l}\text { Análise de aspectos léxico- } \\
\text { semânticos do discurso. }\end{array}$ \\
\hline Incidência de substantivos & $\begin{array}{l}\text { É a incidência de substantivos em um } \\
\text { texto. Quantidade de substantivos / } \\
\text { quantidade de palavras X } 1000 . \\
\text { Recursos de PLN utilizados durante o } \\
\text { cálculo: tokenizador e POS tagger } \\
\text { para identificar os substantivos. }\end{array}$ & $\begin{array}{l}\text { Análise de aspectos léxico- } \\
\text { semânticos do discurso. }\end{array}$ \\
\hline Incidência de adjetivos & $\begin{array}{l}\text { É a incidência de adjetivos em um } \\
\text { texto. Quantidade de adjetivos I } \\
\text { quantidade de palavras X } 1000 \text {. } \\
\text { Recursos de PLN utilizados durante o } \\
\text { cálculo: tokenizador e POS tagger } \\
\text { para identificar os adjetivos. }\end{array}$ & $\begin{array}{l}\text { Análise de aspectos léxico- } \\
\text { semânticos do discurso. }\end{array}$ \\
\hline Incidência de advérbio & $\begin{array}{l}\text { É a incidência de advérbio em um } \\
\text { texto. Quantidade de advérbio } / \\
\text { quantidade de palavras X } 1000 \text {.. } \\
\text { Recursos de PLN utilizados durante o } \\
\text { cálculo: tokenizador e POS tagger } \\
\text { para identificar os advérbios. }\end{array}$ & $\begin{array}{l}\text { Análise de aspectos léxico- } \\
\text { semânticos do discurso. }\end{array}$ \\
\hline Incidência de pronomes & $\begin{array}{l}\text { É a incidência de pronomes em um } \\
\text { texto. Quantidade de pronomes / } \\
\text { quantidade de palavras do texto X } \\
\text { 1000. Recursos de PLN utilizados } \\
\text { durante o cálculo: tokenizador e POS } \\
\text { tagger para identificar os pronomes. }\end{array}$ & $\begin{array}{l}\text { Análise de aspectos léxico- } \\
\text { semânticos do discurso. }\end{array}$ \\
\hline $\begin{array}{l}\text { Incidência de palavras de } \\
\text { conteúdo }\end{array}$ & $\begin{array}{l}\text { E a incidência de palavras de } \\
\text { conteúdo (substantivos, verbos, } \\
\text { adjetivos e advérbios) em um texto. } \\
\text { Quantidade de palavras de conteúdo / } \\
\text { quantidade de palavras X } 1000 . \\
\text { Recursos de PLN utilizados durante } 0\end{array}$ & $\begin{array}{l}\text { Análise de aspectos léxico- } \\
\text { semânticos do discurso. }\end{array}$ \\
\hline
\end{tabular}




\begin{tabular}{|c|c|c|}
\hline & $\begin{array}{l}\text { cálculo: tokenizador e POS tagger } \\
\text { para identificar as palavras de } \\
\text { conteúdo. }\end{array}$ & \\
\hline $\begin{array}{lll}\text { Incidência de palavras } \\
\text { funcionais }\end{array}$ & $\begin{array}{l}\text { É a incidência de palavras funcionais } \\
\text { (artigos, preposições, conjunções, } \\
\text { pronomes e interjeições) em um texto. } \\
\text { Quantidade de palavras funcionais } / \\
\text { quantidade de palavras X } 1000 . \\
\text { Recursos de PLN utilizados durante o } \\
\text { cálculo: tokenizador e POS tagger } \\
\text { para identificar as palavras funcionais. }\end{array}$ & $\begin{array}{l}\text { Análise de aspectos léxico- } \\
\text { semânticos do discurso. }\end{array}$ \\
\hline $\begin{array}{l}\text { Incidência de pronomes } \\
\text { pessoais }\end{array}$ & $\begin{array}{l}\text { É a incidência de pronomes pessoais } \\
\text { em um texto. Quantidade de pronomes } \\
\text { pessoais / quantidade de palavras X } \\
\text { 1000. Recursos de PLN utilizados } \\
\text { durante o cálculo: tokenizador e POS } \\
\text { tagger para identificar os pronomes } \\
\text { pessoais. }\end{array}$ & $\begin{array}{l}\text { Análise de aspectos léxico- } \\
\text { semânticos do discurso. }\end{array}$ \\
\hline Relação tipo por token & $\begin{array}{l}\text { Proporção de palavras sem repetições } \\
\text { (types) em relação ao total de palavras } \\
\text { com repetições (tokens). A métrica só } \\
\text { computa palavras de conteúdo } \\
\text { (substantivos, verbos, advérbios e } \\
\text { adjetivos). Não se usa lematização } \\
\text { das palavras, ou seja, cada flexão é } \\
\text { computada como um type diferente. } \\
\text { Por exemplo, se a palavra cachorro } \\
\text { aparece } 7 \text { vezes em um texto, seu tipo } \\
\text { (type) é } 1 \text { e seu token é } 7 \text {. Quanto } \\
\text { maior o valor da métrica, mais } \\
\text { complexo o texto. Recursos de PLN } \\
\text { utilizados durante o cálculo: } \\
\text { tokenizador e POS tagger para } \\
\text { identificar as palavras de conteúdo. }\end{array}$ & $\begin{array}{l}\text { Fonte para análise de } \\
\text { aspectos léxico-semânticos } \\
\text { do discurso. }\end{array}$ \\
\hline Índice de Brunet & $\begin{array}{l}\text { É uma forma de relação Tipo por } \\
\text { Token menos sensivel ao tamanho do } \\
\text { texto. A quantidade de types considera } \\
\text { palavras sem repetições e a } \\
\text { quantidade de tokens considera } \\
\text { palavras com repetições. Forma de } \\
\text { cálculo da métrica: quantidade de } \\
\text { tokens elevada à quantidade de types } \\
\text { elevada à constante } 0,165 \text {. Os valores } \\
\text { típicos da métrica variam entre } 10 \text { e } \\
20 \text {, sendo que uma fala mais rica } \\
\text { produz valores menores (Thomas et } \\
\text { al., } 2005 \text { ). Recurso de PLN utilizados } \\
\text { durante o cálculo: tokenizador. }\end{array}$ & $\begin{array}{l}\text { Análise de aspectos sintáticos } \\
\text { do discurso. }\end{array}$ \\
\hline Estatística de Honoré & $\begin{array}{l}\text { É uma variação da Relação Tipo por } \\
\text { Token não sensível ao tamanho do } \\
\text { texto, sendo } N \text { o número total de } \\
\text { tokens, } V \_1 \text { é o número de palavras } \\
\text { do vocabulário que aparecem uma } \\
\text { única vez, e } V \text { é o número de types, ou } \\
\text { seja, todas as palavras do texto sem }\end{array}$ & $\begin{array}{l}\text { Análise de aspectos léxico- } \\
\text { semânticos do discurso. }\end{array}$ \\
\hline
\end{tabular}




\begin{tabular}{|l|l|}
\hline contar suas repetições. Cálculo: 100 * \\
$\operatorname{logN} /(1-(\mathrm{V} 1 / \mathrm{V}))$. Quanto mais alto \\
0 valor, mais rico o texto é \\
lexicalmente, o que está associado à \\
maior complexidade. Recurso de PLN \\
utilizados durante o cálculo: \\
tokenizador.
\end{tabular} \mid

\subsubsection{Análise da macroestrutura}

O exame da macroestrutura foi feito manualmente, com base na análise proposições, unidades de significado, próximas do nível conceitual de processamento da linguagem. As proposições foram delimitadas a partir das versões consideradas prototípicas das histórias. Foram definidas 28 proposições para a narrativa da Cinderela, expostas abaixo.

1. Mãe da Cinderela morre

2. Pai da Cinderela casa-se novamente

3. Cinderela e seu pai / falecimento do seu pai

4. Menina rica

5. Inveja (madrasta e filhas)

6. Limpando o sótão/serviçal

7. Deboche e malvadeza

8. Convite para o baile

9. Não permite Cinderela ir ao baile

10. Animais ajudam a fazer o vestido

11. Cinderela feliz com o vestido

12. Filhas da madrasta rasgam vestido da Cinderela

13. Refúgio para a floresta/chorando

14. Fada madrinha aparece

15. Fada madrinha medindo Cinderela para novo vestido 
16. Momento da transformação/abobora-carruagem

17. Fada madrinha faz / da um vestido para Cinderela

18. Fada madrinha avisa para retornar antes da meia noite

19. Foram para o baile

20. Príncipe conhece Cinderela

21. Príncipe dança com Cinderela

22. Meia noite/Cinderela perde sapato na escada

23. Príncipe pega sapato e procura Cinderela

24. Madrasta prende Cinderela no sótão

25. Filha da madrasta experimenta o sapato e não serve

26. Animais soltam Cinderela

27. Cinderela experimenta o sapato e serve

28. Casamento

Para a prancha "Roubo dos Biscoitos" foram utilizadas 7 proposições, apresentadas abaixo.

1. Menino roubando biscoitos

2. Banquinho caindo

3. Mulher lavando louça

4. Água transbordando da pia

5. Ação da menina em direção ao menino

6. Mulher não percebe o transbordamento

7. Copos e pratos já lavados / na cozinha

Para auxílio da análise da macroestrutura, após orientação da equipe do NILC, foi escolhido o programa Deep BonDD (Deep Neural Approach to Boundary and Disfluency Detection) que tem como função segmentar uma 
transcrição em sentenças e remover disfluências. A escolha deste programa teve por objetivo separar as sentenças a fim de classificá-las segundo as proposições. Um profissional experiente no uso do programa, cientista da computação, aplicou-o para examinar todas as transcrições do presente estudo. O programa havia sido aplicado à análise de corpora de

O programa havia sido utilizado na análise de corpora de indivíduos cognitivamente sadios, com doença de Alzheimer e com comprometimento cognitivo leve (Treviso, 2017), porém ainda não havia sido aplicado na análise de enunciações de sujeitos afásicos. Assim sendo, o estudo com afásicos serviu como piloto para validação da aplicabilidade em enunciações que fogem aos padrões da população sadia. Após a segmentação e remoção das disfluências, três profissionais experientes na área (dois fonoaudiólogos e um cientista da computação) iniciaram as marcações das sentenças com suas respectivas proposições por meio da ferramenta de anotação visual e webbased brat (http://brat.n/plab.org/) (Stenetorp et al., 2012) que permite anotar um rico conjunto configurável: trechos de discurso (por exemplo, anotação de entidades nomeadas); relações entre trechos de discurso (por exemplo, anotação de correferência); associações n-áreas sobre um trecho de discurso (por exemplo, vários tipos de eventos) e atributos sobre as anotações. Notouse que as sentenças dos sujeitos do grupo controle estavam adequadas e passíveis de anotação das proposições, porém as sentenças dos sujeitos afásicos estavam mal delimitadas, com remoção de palavras necessárias à sentença, o que dificultou a anotação das proposições. Fonoaudiólogos e cientistas da computação, em consenso, optaram por suspender a anotação 
por meio do método computadorizado e decidiram realiza-la manualmente a fim de que os resultados fossem fidedignos.

No caso dos afásicos, um fator complicador foram as reformulações ou ensaios de reformulação do discurso. Nesse caso, foram excluídas as reformulações anteriores e aceita a última versão, no qual foi utilizada para análise.

Pontuou-se para cada discurso a presença ou ausência de cada proposição na história. Esta pontuação foi realizada por três profissionais com experiência na área e comparadas a fim de se obter consenso.

As proposições da história da Cinderela foram agrupadas de acordo com quatro grandes blocos que compõem a estrutura narrativa:

- Orientação: 1 a 7

- Problema: 9,12, 18, 22, 24

- Desenvolvimento: 8, 10, 11, 13, 14, 15, 16, 17, 19, 20, 21, 23, 25, 26

- Desfecho: 27, 28

Assim, como as proposições da prancha Roubo dos Biscoitos também foram agrupadas, como segue:

- Orientação: 1

- Problema: 2, 4, 6

- Desenvolvimento: 3, 5

- Desfecho: 7 


\subsubsection{Análise estatística}

As características dos parâmetros fonoaudiólogos macroestruturais e microestruturas foram descritas por meio de medianas e intervalos interquartis (IQ25-75), devido à ausência de normalidade das variáveis.

Os parâmetros macro e microestruturais do discurso foram comparados conforme segue:

a) Comparação dos parâmetros entre grupo de controles sadios e afásicos, por meio do teste não paramétrico de Mann- Whitney.

b) Comparação dos parâmetros de micro e macroestrutura, do discursos da prancha Roubo dos Biscoitos vs Cinderela, produzido - até 1 mês após o AVC entre afásicos de Broca e afásicos anômicos, por meio do teste não paramétrico de Mann- Whitney.

c) Comparação das métricas de micro e macro estrutura dos discursos da prancha do Roubo dos Biscoitos e Cinderela, segundo tempo de acompanhamento (até 1 mês, 3 e 6 meses após o AVC), por meio do teste não paramétrico pareado de Wilcoxon.

d) Comparação dos parâmetros de micro e macroestrutura entre as histórias Roubo dos Biscoitos vs. Cinderela, produzidas até um mês, 3 e 6 meses após o AVC, por meio do teste não paramétrico de Mann- Whitney.

e) Comparação dos parâmetros macroestruturais dos discursos produzidos até 1 mês, 3 e 6 meses do AVC, utilizando-se o teste não paramétrico de Wilcoxon sign rank.

Devido às variações na emissão de cada uma das proposições tanto no grupo GC quanto nos grupos GA1 e GA2, para proceder às análises comparativas entre variáveis, optou-se por gerar um índice. Todos os índices 
foram comparados dois a dois para saber se existia diferença entre eles, então para que eles se tornassem comparáveis, ou seja, tivessem a mesma escala (número mínimo e número máximo), foi criada uma proporção de acertos que variava de 0 a 1 , como se fosse uma porcentagem de acertos (0\% a 100\%) que foi calculado de acordo com o número de proposições de cada índice de cada história.

Os dados foram processados por meio do software Stata 13.0, em todas as análises adotou-se como nível de significância estatística $p<0,05$. 


\section{RESULTADOS}

\subsection{Composição e caracterização da amostra}

A amostra desta pesquisa foi composta por 53 indivíduos distribuídos em três grupos, GC, GA1 e GA2.

O GC foi composto de 30 indivíduos: 8 do sexo masculino e 22 do sexo feminino. A mediana de idade desse grupo foi 65 e a de escolaridade foi 11 . Todos os indivíduos do GC preencheram os critérios do estudo MOANS (Smith, 2003). Os desempenhos dos sujeitos do GC nos testes de Fluência Verbal (FV) - animais (Brucki, Rocha, 2004) e fonêmica (Machado et al, 2009) e MEEM (Folstein et al., 1975) estão apresentados na tabela 1.

Tabela 1- Resultados das avaliações Fluência Verbal - animais e fonêmica e MEEM dos indivíduos cognitivamente sadios.

\begin{tabular}{|c|c|c|c|c|c|}
\hline Sujeito & Idade & Escolaridade & $\begin{array}{l}\text { Fluência verbal } \\
\text { semântica* }^{*}\end{array}$ & $\begin{array}{l}\text { Fluência } \\
\text { verbal } \\
\text { fonêmica - F } \\
\text { A S* }^{*}\end{array}$ & MEEM $^{* *}$ \\
\hline 1 & 80 & 11 & 14 & 31 & 29 \\
\hline 2 & 64 & 15 & 14 & 51 & 30 \\
\hline 3 & 72 & 11 & 14 & 50 & 30 \\
\hline 4 & 61 & 15 & 20 & 42 & 30 \\
\hline 5 & 95 & 14 & 13 & 31 & 29 \\
\hline 6 & 83 & 6 & 14 & 25 & 29 \\
\hline 7 & 83 & 7 & 10 & 26 & 30 \\
\hline 8 & 76 & 11 & 15 & 50 & 30 \\
\hline 9 & 66 & 12 & 19 & 41 & 30 \\
\hline 10 & 67 & 15 & 16 & 38 & 30 \\
\hline 11 & 92 & 11 & 14 & 25 & 28 \\
\hline 12 & 72 & 11 & 18 & 30 & 30 \\
\hline 13 & 72 & 12 & 18 & 41 & 29 \\
\hline 14 & 62 & 11 & 15 & 32 & 28 \\
\hline 15 & 62 & 15 & 17 & 51 & 30 \\
\hline 16 & 85 & 15 & 15 & 40 & 30 \\
\hline 17 & 66 & 11 & 13 & 23 & 27 \\
\hline 18 & 92 & 6 & 11 & 28 & 28 \\
\hline 19 & 61 & 11 & 14 & 24 & 30 \\
\hline 20 & 85 & 14 & 14 & 33 & 29 \\
\hline 21 & 47 & 10 & 20 & 28 & 30 \\
\hline 22 & 37 & 10 & 28 & 40 & 29 \\
\hline 23 & 35 & 11 & 21 & 39 & 28 \\
\hline 24 & 49 & 11 & 18 & 32 & 30 \\
\hline 25 & 61 & 11 & 14 & 24 & 30 \\
\hline 26 & 37 & 18 & 18 & 27 & 28 \\
\hline 27 & 56 & 10 & 10 & 20 & 27 \\
\hline 28 & 47 & 14 & 19 & 30 & 26 \\
\hline
\end{tabular}




\begin{tabular}{cccccc}
\hline $\mathbf{2 9}$ & 43 & 11 & 18 & 30 & 26 \\
$\mathbf{3 0}$ & 54 & 10 & 17 & 31 & 28 \\
\hline
\end{tabular}

Legenda: $*$ Total de itens emitidos em 1 minuto. **= Pontuação total (acertos).

O GA1 foi composto por 8 indivíduos afásicos, sendo 6 com afasia de Broca e 2 com afasia anômica. Para a constituição desse grupo, foram triados pacientes com diagnóstico de AVC que deram entrada no pronto-socorro do HCFMUSP entre os períodos de março de 2016 e agosto de 2017. A triagem dos pacientes consistiu em selecionar os pacientes com AVC em lesão única de hemisfério esquerdo com alteração de linguagem com provável diagnóstico de afasia de Broca ou afasia anômica. Após a seleção destes pacientes, aplicou-se o Teste de Boston para o Diagnóstico de Afasia (Goodglass, op. cit) para realizar o diagnóstico fonoaudiológico quanto ao subtipo da afasia. Os pacientes que não compareceram a às avaliações propostas no estudo foram excluídos da pesquisa. A figura 2 mostra o processo de inclusão dos sujeitos no GA1.

Figura 2 - Processo de inclusão dos sujeitos no GA1.

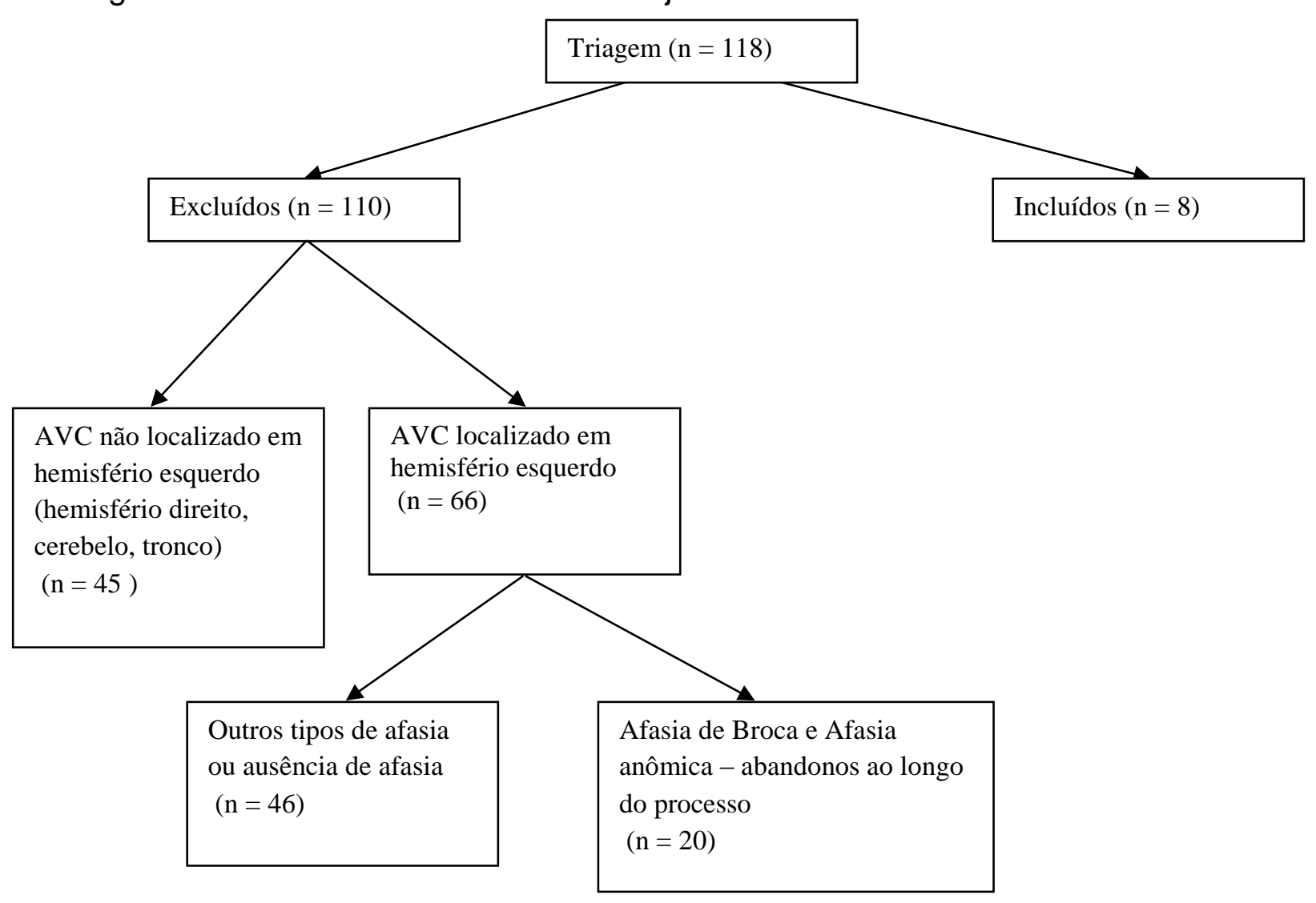


As características dos sujeitos incluídos no GA1 se encontram na tabela 2.

Tabela 2 - Características dos sujeitos do GA1.

\begin{tabular}{ccccccc}
\hline Sujeito & Idade & Escolaridade & Sexo & Tipo de afasia e co-morbidades & $\begin{array}{c}\text { Pontuação } \\
\text { gravidade } \\
\text { da afasia }\end{array}$ & $\begin{array}{c}\text { Inteligibilidade } \\
\text { de fala }\end{array}$ \\
\hline 1 & 48 & 5 & M & Afasia de Broca & 2 & 6 \\
2 & 51 & 5 & F & Afasia de Broca + Apraxia de fala & 2 & 7 \\
3 & 56 & 11 & M & Afasia Anômica & 2 & 9 \\
4 & 66 & 8 & F & Afasia de Broca + Apraxia de fala + & 2 & 5 \\
5 & 49 & 3 & M & Afasia de Broca + Apraxia de fala + & 3 & 5 \\
6 & 48 & 8 & F & Disartria & 3 & 9 \\
7 & 92 & 4 & F & Afasia de Broca + Apraxia de fala + & 2 & 5 \\
8 & 39 & 6 & F & Afasia de Broca + Apraxia de fala & 4 & 5 \\
\hline
\end{tabular}

Os resultados de exames de imagem (tomografia computadorizada e SPECT) que mostram os locais de lesão do GA1 estão presentes na tabela 3. Os dados do SPECT até um mês após o AVC e 6 meses após o AVC permaneceram o mesmo. Ou seja, não houve mudanças no metabolismo cerebral durante este período. 
Tabela 3 - Resultados de exames de imagem que mostram os locais de lesão do GA1.

\begin{tabular}{|c|c|c|}
\hline Sujeito & Tomografia computadorizada (TC) & SPECT (até um mês após o AVC X 6 meses após o AVC) \\
\hline 1 & $\begin{array}{l}\text { Frontal, temporal, parietal anterior, } \\
\text { núcleos da base e tálamo à esquerda }\end{array}$ & $\begin{array}{l}\text { Frontal, temporal, parietal anterior, núcleos da base e tálamo } \\
\text { à esquerda; hemisfério cerebelar à direita (diasquise) }\end{array}$ \\
\hline 2 & Fronto-parietal e ínsula esquerda & Fronto-parietal e ínsula esquerda \\
\hline 3 & $\begin{array}{l}\text { Núcleos da base, ínsula, frontal inferior e } \\
\text { médio à esquerda }\end{array}$ & $\begin{array}{l}\text { Ausência de perfusão em núcleos da base à esquerda; } \\
\text { hipoperfusão discreta em tálamo à esquerda; hipoperfusão } \\
\text { moderada em todo o lobo frontal e em temporal anterior à } \\
\text { esquerda }\end{array}$ \\
\hline 4 & $\begin{array}{l}\text { Occipital e temporal à esquerda (inclui } \\
\text { giros fusiforme e temporal inferior); frontal } \\
\text { e parietal à esquerda + ínsula }\end{array}$ & $\begin{array}{l}\text { Ausência de perfusão em Frontal inferior e médio + ínsula + } \\
\text { núcleos da base à esquerda. Hipoperfusão em frontal } \\
\text { superior (maior do que é observado na TC). Hipoperfusão em } \\
\text { occipital e temporal relacionados ao } 1^{\circ} \text { AVC. Discreta } \\
\text { hipoperfusão em todo o hemisfério esquerdo }\end{array}$ \\
\hline 5 & $\begin{array}{l}\text { Frontal inferior, médio e superior, ínsula e } \\
\text { núcleos da base à esquerda }\end{array}$ & $\begin{array}{l}\text { Ausência de perfusão em frontal inferior, médio e superior, } \\
\text { ínsula e núcleos da base à esquerda; hipoperfusão em frontal } \\
\text { superior (em área maior que a visualizada na TC) e em todo } \\
\text { o hemisfério cerebral esquerdo }\end{array}$ \\
\hline 6 & Temporal, parietal e ínsula esquerda & Temporal, parietal e ínsula esquerda \\
\hline 7 & $\begin{array}{l}\text { Frontal inferior (opérculo + giro pré-central } \\
\text { inferior) + ínsula }\end{array}$ & $\begin{array}{l}\text { Ausência de fluxo em frontal e ínsula esquerda. Discreta } \\
\text { hipoperfusão em parietal, temporal, núcleos da base e tálamo } \\
\text { à esquerda (diasquise) }\end{array}$ \\
\hline 8 & $\begin{array}{l}\text { Lesão pequena na transição têmporo- } \\
\text { parietal esquerda }\end{array}$ & $\begin{array}{l}\text { Ausência de fluxo em temporal com extensão para parietal, à } \\
\text { esquerda (esta área é maior que a observada na TC). } \\
\text { Hipoperfusão em todo o temporal esquerdo (sem } \\
\text { correspondência na TC). Hipoperfusão em tálamo direito }\end{array}$ \\
\hline
\end{tabular}

O GA2, grupo que será comparado ao GC, foi composto por 15

indivíduos afásicos, sendo 7 com afasia de Broca e 8 com afasia anômica. A mediana de idade desse grupo foi 52 e a de escolaridade foi 8 . Este grupo foi formado por afásicos que realizaram avaliação de linguagem no Ambulatório de Linguagem do HCFMUSP, independente do tempo de lesão. As características do GA2 estão presentes na tabela 4. 
Tabela 4 - Características dos sujeitos do GA2.

\begin{tabular}{|c|c|c|c|c|c|c|c|}
\hline Sujeito & Idade & $\begin{array}{c}\text { Escolarida } \\
\text { de }\end{array}$ & Gênero & Local de lesão & $\begin{array}{c}\text { Tipo de } \\
\text { afasia e co- } \\
\text { morbidades }\end{array}$ & $\begin{array}{c}\text { Gravidad } \\
\text { e da } \\
\text { afasia } \\
\end{array}$ & $\begin{array}{l}\text { Inteligibilidade } \\
\text { de fala }\end{array}$ \\
\hline 1 & 35 & 16 & $\bar{M}$ & $\begin{array}{c}\text { Frontal inferior, } \\
\text { médio e superior + } \\
\text { Temporal anterior + } \\
\text { insula anterior, à } \\
\text { esquerda }\end{array}$ & $\begin{array}{c}\text { Afasia de } \\
\text { Broca + } \\
\text { Apraxia de } \\
\text { fala + } \\
\text { Disartria }\end{array}$ & 3 & 8 \\
\hline 2 & 38 & 11 & $F$ & $\begin{array}{l}\text { Artéria cerebral } \\
\text { média à esquerda } \\
\text { (laudo não } \\
\text { especificado) }\end{array}$ & $\begin{array}{c}\text { Afasia } \\
\text { Anômica }\end{array}$ & 5 & 9 \\
\hline 3 & 39 & 11 & $F$ & $\begin{array}{l}\text { Temporoparietal à } \\
\text { esquerda }\end{array}$ & $\begin{array}{c}\text { Afasia de } \\
\text { Broca }\end{array}$ & 4 & 8 \\
\hline 4 & 40 & 11 & $\mathrm{M}$ & $\begin{array}{l}\text { Nucleocapsular à } \\
\text { esquerda }\end{array}$ & $\begin{array}{l}\text { Afasia de } \\
\text { Broca + } \\
\text { Apraxia de } \\
\text { fala }\end{array}$ & 2 & 5 \\
\hline 5 & 44 & 8 & M & $\begin{array}{c}\text { Frontoparietal à } \\
\text { esquerda + } \\
\text { frontoparietal à } \\
\text { direita antiga }\end{array}$ & $\begin{array}{c}\text { Afasia de } \\
\text { Broca }\end{array}$ & 2 & 5 \\
\hline 6 & 46 & 5 & $F$ & $\begin{array}{l}\text { Frontotemporopariet } \\
\text { al à esquerda }\end{array}$ & $\begin{array}{c}\text { Afasia de } \\
\text { Broca }\end{array}$ & 2 & 6 \\
\hline 7 & 46 & 8 & $F$ & Parietal à esquerda & $\begin{array}{c}\text { Afasia } \\
\text { Anômica + } \\
\text { Apraxia de } \\
\text { fala }\end{array}$ & 4 & 9 \\
\hline 8 & 52 & 5 & M & $\begin{array}{l}\text { Artéria cerebral } \\
\text { média à esquerda } \\
\text { (laudo não } \\
\text { especificado) }\end{array}$ & $\begin{array}{c}\text { Afasia de } \\
\text { Broca + } \\
\text { Apraxia de } \\
\text { fala }+ \\
\text { Disartria }\end{array}$ & 2 & 5 \\
\hline 9 & 55 & 8 & M & Parietal à esquerda & $\begin{array}{c}\text { Afasia } \\
\text { Anômica }\end{array}$ & 4 & 8 \\
\hline 10 & 56 & 10 & M & $\begin{array}{c}\text { Temporo-occipital à } \\
\text { esquerda }\end{array}$ & $\begin{array}{l}\text { Afasia } \\
\text { Anômica }\end{array}$ & 4 & 9 \\
\hline 11 & 60 & 8 & $\mathrm{~F}$ & $\begin{array}{c}\text { Frontal e occipital à } \\
\text { esquerda }\end{array}$ & $\begin{array}{l}\text { Afasia } \\
\text { Anômica }\end{array}$ & 4 & 9 \\
\hline 12 & 67 & 8 & $F$ & $\begin{array}{c}\text { Frontoparietal à } \\
\text { esquerda }\end{array}$ & $\begin{array}{l}\text { Afasia } \\
\text { Anômica }\end{array}$ & 4 & 8 \\
\hline 13 & 71 & 4 & M & $\begin{array}{l}\text { Artéria cerebral } \\
\text { média à esquerda }\end{array}$ & $\begin{array}{c}\text { Afasia } \\
\text { Anômica + } \\
\text { Apraxia de } \\
\text { fala }\end{array}$ & 4 & 9 \\
\hline 14 & 71 & 11 & M & Parietal à esquerda & $\begin{array}{l}\text { Afasia } \\
\text { Anômica }\end{array}$ & 4 & 8 \\
\hline 15 & 77 & 8 & M & $\begin{array}{c}\text { Artéria cerebral } \\
\text { média à esquerda }\end{array}$ & $\begin{array}{c}\text { Afasia de } \\
\text { Broca }\end{array}$ & 3 & 7 \\
\hline
\end{tabular}




\subsection{Análise do estudo 1}

A tabela 5 compara e descreve as características sociodemográficas e os parâmetros de análise da macro e microestrutura do GC e G2.

Tabela 5 - Comparação do discurso no nível de macroestrutura e microestrutura entre o GC e o G2. História da Cinderela.

\begin{tabular}{|c|c|c|c|c|c|}
\hline \multirow[t]{2}{*}{ Variável } & \multicolumn{2}{|c|}{$G C(n=30)$} & \multicolumn{2}{|c|}{ G2 (n=15) } & \multirow[b]{2}{*}{$\rho^{* *}$} \\
\hline & $\begin{array}{c}\text { Mediana } \\
\text { (IQ) }\end{array}$ & Min-max & $\begin{array}{c}\text { Mediana } \\
\text { (IQ) }\end{array}$ & Min-max & \\
\hline Idade & $65(54-80)$ & $35-95$ & $51(44-66)$ & $35-92$ & 0,016 \\
\hline Escolaridade & $11(11-14)$ & $6-18$ & $8(5-11)$ & $3-16$ & $<0,001$ \\
\hline \multicolumn{6}{|l|}{ Macroestrutura } \\
\hline Orientação & $0,43(0,29-0,57)$ & $0-0,86$ & $0,14(0-0,14)$ & $0-0,85$ & $<0,001$ \\
\hline Problema & $0,6(0,4-0,8)$ & $0,4-1$ & $0(0-0,20)$ & $0-0,8$ & $<0,001$ \\
\hline Desenvolvimento & $0,57(0,43-0,64)$ & $0,14-0,78$ & $0,71(0-0,21)$ & $0-0,64$ & $<0,001$ \\
\hline Desfecho & $1(0,5-1)$ & $0,5-1$ & $0(0-0,5)$ & $0-1$ & $<0,001$ \\
\hline Total proposições* & $0,57(0,46-0,64)$ & $0,29-0,86$ & $0,07(0-0,25)$ & $0-0,53$ & $<0,001$ \\
\hline \multicolumn{6}{|l|}{ Microestrutura } \\
\hline $\begin{array}{l}\text { Palavras ausentes no } \\
\text { dicionário }\end{array}$ & $10,50(3,46-24,63)$ & $0-47,39$ & $\begin{array}{r}69,42(23,60- \\
129,03)\end{array}$ & $0-609,19$ & $<0,001$ \\
\hline Leiturabilidade (Flesch) & $\begin{array}{r}-221,53(-322,47- \\
133,12)\end{array}$ & $\begin{array}{r}-732,60-- \\
44,09\end{array}$ & $\begin{array}{r}-95,42(-288,37- \\
16,22)\end{array}$ & $\begin{array}{r}-629,88- \\
83,42\end{array}$ & 0,006 \\
\hline Número de palavras & 299 (223-409) & $129-804$ & $192(116-378)$ & $34-727$ & 0,015 \\
\hline $\begin{array}{l}\text { Sílabas/ palavra de } \\
\text { conteúdo }\end{array}$ & $2,33(2,25-2,39)$ & $2,13-2,75$ & $2,04(1,89-2,22)$ & $1,37-2,78$ & $<0,001$ \\
\hline Incidência de verbos & $\begin{array}{r}233,62(221,86- \\
248,66)\end{array}$ & $\begin{array}{r}163,97- \\
299,43\end{array}$ & $\begin{array}{r}206,59(146,85- \\
233,83)\end{array}$ & $\begin{array}{l}25,00- \\
244,90\end{array}$ & $<0,001$ \\
\hline $\begin{array}{l}\text { Incidência de } \\
\text { substantivos }\end{array}$ & $\begin{array}{r}230,06(212,69- \\
254,04)\end{array}$ & $\begin{array}{r}171,15- \\
306,67\end{array}$ & $\begin{array}{r}187,05(148,93- \\
280,00)\end{array}$ & $42,25-562,5$ & 0,897 \\
\hline Incidência de adjetivos & $26,73(19,76-31,53)$ & $8,43-38,80$ & $18,52(4,39-29,41)$ & $0-337,5$ & 0,051 \\
\hline $\begin{array}{l}\text { Incidência de } \\
\text { advérbios }\end{array}$ & $66,04(57,97-80,21)$ & $33,71-103,23$ & $\begin{array}{r}77,58(49,75- \\
140,27)\end{array}$ & $\begin{array}{r}229,17- \\
91,03\end{array}$ & 0,306 \\
\hline $\begin{array}{l}\text { Incidência de } \\
\text { pronomes }\end{array}$ & $\begin{array}{r}140,02(123,55- \\
163,31)\end{array}$ & $70,83-182,79$ & $\begin{array}{r}145,07(109,45- \\
193,12)\end{array}$ & $0-285,71$ & 0,451 \\
\hline $\begin{array}{l}\text { Incidência de palavras } \\
\text { de conteúdo }\end{array}$ & $\begin{array}{r}558,30(544,93- \\
572,91)\end{array}$ & $\begin{array}{r}482,67- \\
620,83\end{array}$ & $\begin{array}{r}541,95(451,83- \\
575,54)\end{array}$ & $428,57-925$ & 0,131 \\
\hline $\begin{array}{l}\text { Incidência de palavras } \\
\text { funcionais }\end{array}$ & $\begin{array}{r}416,57(399,30- \\
434,78)\end{array}$ & $\begin{array}{r}345,83- \\
496,53\end{array}$ & $\begin{array}{r}425,53(381,29- \\
502,29)\end{array}$ & $75-549,29$ & 0,269 \\
\hline $\begin{array}{l}\text { Incidência de } \\
\text { pronomes pessoais }\end{array}$ & $68,11(51,38-77,52)$ & $30,30-112,90$ & $68,96(29,82-94,42)$ & 0167,42 & 0,850 \\
\hline $\begin{array}{l}\text { Relação Tipo por } \\
\text { Token }\end{array}$ & $0,46(0,40-0,49)$ & $0,32-0,55$ & $0,39(0,27-0,47)$ & $0,11-0,59$ & 0,014 \\
\hline Índice de Brunet & $12,55(12,02-13,23)$ & $11,31-14,43$ & $12,99(11,64-15,48)$ & $8,59-21,10$ & 0,172 \\
\hline Estatística de Honoré & $\begin{array}{r}654,84(608,42- \\
715,08) \\
\end{array}$ & $\begin{array}{r}508,08- \\
807,16 \\
\end{array}$ & $\begin{array}{r}528,10(429,58- \\
585,53) \\
\end{array}$ & $\begin{array}{r}219,83- \\
806,18 \\
\end{array}$ & $<0,001$ \\
\hline
\end{tabular}


Nota-se que o GA2 apresenta idade e escolaridade significativamente menor que o GC.

Com relação à macroestrutura, o GA2 se diferenciou significativamente do GC em todas as proposições. Observa-se que os indivíduos cognitivamente sadios apresentaram proporção significativamente maior de acertos para todos os parâmetros macroestruturais com exceção do desenvolvimento, que foi significantemente maior entre os afásicos.

Quanto à microestrutura dos 15 parâmetros avaliados, sete indicaram diferenças significativas entre os grupos, sendo: incidência de palavras ausentes no dicionário, índice de leiturabilidade Flesch, quantidade de palavras, sílabas por palavra de conteúdo, índice de verbos, relação Tipo por Token, estatística de Honoré. Todas estas métricas foram significantemente maiores no GC, com exceção dos parâmetros incidência de palavras ausentes no dicionário e índice de leiturabilidade Flesch.

A tabela 6 apresenta a comparação da análise da macroestrutura e da microestrutura entre os dois tipos de afasia no G2. 
Tabela 6 - Comparação de discurso (nível macro e microestrutura), segundo tipo de Síndrome de Afasia. História Cinderela $(n=15)$.

\begin{tabular}{|c|c|c|c|c|c|}
\hline \multirow[t]{2}{*}{ Variável } & \multicolumn{2}{|c|}{ Broca $(n=7)$} & \multicolumn{2}{|c|}{ Anomica $(n=8)$} & \multirow[b]{2}{*}{$P^{* *}$} \\
\hline & $\begin{array}{c}\text { Mediana } \\
\text { (IQ) }\end{array}$ & Min-max & $\begin{array}{c}\text { Mediana } \\
\text { (IQ) }\end{array}$ & Min-max & \\
\hline \multicolumn{6}{|l|}{ Macroestrutura } \\
\hline Orientação & $0(0-0,14)$ & $0,00-0,28$ & $0,14(0,14-0,14)$ & $0-0,28$ & 0,058 \\
\hline Problema & $0(0,00-0,0)$ & $0,00-0,60$ & $0,10(0,00-0,60)$ & $0-0,8$ & 0,124 \\
\hline Desenvolvimento & $0(0,00-0,14)$ & $0,00-0,50$ & $0,18(0,07-0,50)$ & $0-0,64$ & 0,037 \\
\hline Desfecho & $0(0,00-0,00)$ & $0,00-1,00$ & $0,5(0,00-0,50)$ & $0,00-0,50$ & 0,098 \\
\hline Total de proposições* & $0,07(0,00-0,14)$ & $0-0,5$ & $0,18(0,03-0,43)$ & $0,03-0,53$ & 0,019 \\
\hline \multicolumn{6}{|l|}{ Microestrutura } \\
\hline $\begin{array}{l}\text { Incidência de palavras } \\
\text { ausentes no dicionário }\end{array}$ & $70,33(46,67-134,33)$ & $13,89-609,19$ & $31,26(8,55-47,39)$ & $0-82,68$ & 0,018 \\
\hline $\begin{array}{l}\text { Índice de leiturabilidade } \\
\text { Flesch }\end{array}$ & $-95,42(-319,44-1,80)$ & $-629,88-83,42$ & $\begin{array}{r}-91,25(-172,44 ;- \\
39,79)\end{array}$ & $\begin{array}{r}-361,36 ;- \\
16,22\end{array}$ & 0,852 \\
\hline Quantidade de palavras & $192(71-436)$ & $34-727$ & $193,5(139-247)$ & $116-455$ & 0,901 \\
\hline $\begin{array}{l}\text { Sílabas por palavra de } \\
\text { conteúdo }\end{array}$ & $1,95(1,86-2,04)$ & $1,37-2,78$ & $2,18(2,08-2,33)$ & $2,02-2,57$ & 0,015 \\
\hline Incidência de verbos & $\begin{array}{r}203,62(146,85- \\
212,34)\end{array}$ & $25-244,89$ & $\begin{array}{r}211,21(184,05- \\
238,09)\end{array}$ & $144-241,38$ & 0,352 \\
\hline $\begin{array}{l}\text { Incidência de } \\
\text { substantivos }\end{array}$ & $\begin{array}{r}163,26(145,83- \\
286,69)\end{array}$ & $42,25-562,5$ & $\begin{array}{r}211,11(177,42- \\
258,62)\end{array}$ & $\begin{array}{r}134,97- \\
319,84\end{array}$ & 0,709 \\
\hline Incidência de adjetivos & $20,63(13,76-28,17)$ & $0-337,5$ & $8,05(4,39-34,33)$ & $0-53,76$ & 0,574 \\
\hline Incidência de advérbios & $90,91(51,72-169,01)$ & $0-229,17$ & $\begin{array}{r}68,84(49,75- \\
111,11)\end{array}$ & $16-165,46$ & 0,619 \\
\hline $\begin{array}{l}\text { Incidência de } \\
\text { pronomes }\end{array}$ & $\begin{array}{r}154,2(117,65- \\
194,57)\end{array}$ & $0-285,71$ & $\begin{array}{r}136,94(109,45- \\
165,46)\end{array}$ & $\begin{array}{l}93,12- \\
248,00\end{array}$ & 0,619 \\
\hline $\begin{array}{l}\text { Incidência de palavras } \\
\text { de conteúdo }\end{array}$ & $\begin{array}{r}541,96(451,83- \\
572,21)\end{array}$ & $428,57-925$ & $\begin{array}{r}549,89(467,67- \\
575,54)\end{array}$ & $\begin{array}{r}430,11- \\
578,02\end{array}$ & 0,901 \\
\hline $\begin{array}{l}\text { Incidência de palavras } \\
\text { funcionais }\end{array}$ & $\begin{array}{r}398,90(333,33- \\
502,29)\end{array}$ & $75-577,46$ & $\begin{array}{r}436,51(415,05- \\
493,58)\end{array}$ & $378,02-536$ & 0,664 \\
\hline $\begin{array}{l}\text { Incidência de } \\
\text { pronomes pessoais }\end{array}$ & $34,48(14,08-90,42)$ & $0-167,42$ & $74,75(61,54-94,42)$ & $\begin{array}{l}48,58- \\
100,71\end{array}$ & 0,153 \\
\hline Relação Tipo por Token & $0,28(0,27-0,39)$ & $0,11-0,59$ & $0,43(0,4-0,50)$ & $0,30-0,54$ & 0,025 \\
\hline Índice de Brunet & $15,04(12,50-15,69)$ & $8,59-21,104$ & $12,51(11,64-12,99)$ & $11,31-15,07$ & 0,121 \\
\hline Estatística de Honoré & $\begin{array}{r}516,22(401,42- \\
581,42) \\
\end{array}$ & $\begin{array}{r}219,84- \\
596,30 \\
\end{array}$ & $\begin{array}{r}541,06(468,47- \\
601,09) \\
\end{array}$ & $\begin{array}{r}429,58- \\
806,18 \\
\end{array}$ & 0,153 \\
\hline
\end{tabular}

*Soma das proposições: Orientação, Problema, desenvolvimento e Desfecho;

** teste não paramétrico de Mann-Whitney

A comparação entre os parâmetros de análise, no nível macro e micro estrutural, na história Cinderela, entre afásicos anômicos e de Broca, no GA2, indicou que sujeitos afásicos anômicos apresentaram proporção significativamente maior de número de proposições nos blocos desenvolvimento e no total de proposições (nível macro), bem como maiores valores medianos para as variáveis sílabas por palavra de conteúdo e relação 
Tipo por Token em relação aos afásicos de Broca. Já o parâmetro incidência de palavras ausentes no dicionário mostrou-se significativamente menor entre os afásicos anômicos.

\subsection{Análise do estudo 2}

As tabelas a seguir apresentam as análises do discurso nos níveis de macroestrutura e microestrutura do GA1, por meio da prancha Roubo dos Biscoitos. 
Tabela 7 - Comparação de discurso no nível de macroestrutura e microestrutura, segundo tempo de acompanhamento. História Biscoito $(n=8)$.

\begin{tabular}{|c|c|c|c|c|c|c|}
\hline \multirow[t]{2}{*}{ Variável } & \multicolumn{2}{|c|}{ Até 1 mês ${ }^{a}(n=8)$} & \multicolumn{2}{|c|}{ Após 3 meses $^{b}(n=8)$} & \multicolumn{2}{|c|}{ Após 6 meses $^{c}(n=8)$} \\
\hline & $\begin{array}{l}\text { Mediana } \\
\text { (IQ) }\end{array}$ & Min-max & $\begin{array}{l}\text { Mediana } \\
\text { (IQ) }\end{array}$ & Min-max & $\begin{array}{l}\text { Mediana } \\
\text { (IQ) }\end{array}$ & Min-max \\
\hline \multicolumn{7}{|l|}{ Macroestrutura } \\
\hline Orientação & $0(0-0)^{a b-a c}$ & $0-0$ & $0(0-1)$ & $0-1$ & $0(0-1)$ & $0-1$ \\
\hline Problema & $0,1(0-0,17)^{\text {ac }}$ & $0-0,67$ & $0(0-0,5)$ & $0-0,66$ & $0,67(0-0,66)$ & $0-1$ \\
\hline Desenvolvimento & $0,18(0,03-0,5)$ & $0-0,5$ & $0,5(0,25-0,5)$ & $0-1$ & $0,25(0-0,5)$ & $0-1$ \\
\hline Desfecho & $0(0-0)$ & $0-0,0$ & $0,25(0-0,5)$ & $0-1$ & $0(0-0)$ & $0-0,0$ \\
\hline $\begin{array}{l}\text { Total de } \\
\text { proposições* }\end{array}$ & $0,0(0,0-0,21)$ ac & $0-0,71$ & $0,28(0,07-0,5)$ & $0-0,71$ & $0,43(0-0,57)$ & $0-0,71$ \\
\hline \multicolumn{7}{|l|}{ Microestrutura } \\
\hline $\begin{array}{l}\text { Incidência de } \\
\text { palavras } \\
\text { presentes no } \\
\text { dicionário }\end{array}$ & $\begin{array}{r}126,24(86,02- \\
145,17)^{a b}\end{array}$ & $0-230,77$ & $\begin{array}{r}76,56(30,41- \\
124,51)\end{array}$ & $0-138,46$ & $\begin{array}{r}95,24(81,36- \\
113,52)\end{array}$ & $\begin{array}{l}55,56- \\
115,79\end{array}$ \\
\hline $\begin{array}{l}\text { Índice de } \\
\text { leiturabilidade } \\
\text { Flesch }\end{array}$ & $\begin{array}{r}74,94(48,94- \\
98,36)\end{array}$ & $\begin{array}{l}21,86- \\
127,16\end{array}$ & $\begin{array}{r}64,98(43,09- \\
70,82)\end{array}$ & $\begin{array}{r}26,2- \\
101,68\end{array}$ & $\begin{array}{r}59,95(14,29- \\
74,66)\end{array}$ & $6,46-82,44$ \\
\hline $\begin{array}{l}\text { Quantidade de } \\
\text { palavras }\end{array}$ & $31(22,5-60)$ & $10-86$ & $49(24,5-61,5)$ & $14-74$ & $\begin{array}{r}36,5(33,5- \\
85)\end{array}$ & $25-90$ \\
\hline $\begin{array}{l}\text { Sílabas por } \\
\text { palavra de } \\
\text { conteúdo }\end{array}$ & $\begin{array}{r}1,94(1,72-2,13) \\
\text { ac }\end{array}$ & $1,17-2,36$ & $2,13(1,89-2,27)$ & $1,59-2,42$ & $\begin{array}{r}2,11(2,01- \\
2,45)\end{array}$ & $1,94-2,5$ \\
\hline $\begin{array}{l}\text { Incidência de } \\
\text { verbos }\end{array}$ & $\begin{array}{r}183,67(99,30- \\
304,05)\end{array}$ & $\begin{array}{r}88,23- \\
388,88\end{array}$ & $\begin{array}{r}208,49(163,03- \\
269,17)\end{array}$ & $\begin{array}{l}71,43- \\
333,33\end{array}$ & $\begin{array}{r}174,24(60,69 \\
-221,98)\end{array}$ & $\begin{array}{l}29,41- \\
256,41\end{array}$ \\
\hline $\begin{array}{l}\text { Incidência de } \\
\text { substantivos }\end{array}$ & $\begin{array}{r}235,46(145,73- \\
279,62) \text { ac }\end{array}$ & $0-323,52$ & $\begin{array}{r}224,74(178,49- \\
264,88)^{\text {bc }}\end{array}$ & $\begin{array}{r}121,62- \\
285,71\end{array}$ & $\begin{array}{r}292,18(272,3 \\
5-321,42)\end{array}$ & $\begin{array}{r}211,11- \\
352,94\end{array}$ \\
\hline $\begin{array}{l}\text { Incidência de } \\
\text { adjetivos }\end{array}$ & $0(0-17,86)$ & $0-300$ & $0(0-18,66)$ & $0-37,04$ & $0(0-0)$ & $0-11,90$ \\
\hline $\begin{array}{l}\text { Incidência de } \\
\text { advérbios }\end{array}$ & $\begin{array}{r}139,77(64,08- \\
241,83)\end{array}$ & $0-285,71$ & $\begin{array}{r}113,31(46,16- \\
188,46)\end{array}$ & $\begin{array}{r}23,81- \\
357,14\end{array}$ & $\begin{array}{r}71,00(25,64- \\
97,61)\end{array}$ & $0-117,64$ \\
\hline $\begin{array}{l}\text { Incidência de } \\
\text { pronomes }\end{array}$ & $\begin{array}{r}78,71(0,00- \\
151,40)\end{array}$ & $0-178,57$ & $\begin{array}{r}60,68(23,43- \\
129,87)\end{array}$ & $0-181,81$ & $\begin{array}{r}55,05(32,59- \\
154,06)\end{array}$ & $0-233,33$ \\
\hline $\begin{array}{l}\text { Incidência de } \\
\text { palavras de } \\
\text { conteúdo }\end{array}$ & $\begin{array}{r}642,16(514,36- \\
700,16) \text { ac }\end{array}$ & $\begin{array}{r}295,77- \\
800\end{array}$ & $\begin{array}{r}549,75(500- \\
654,76)\end{array}$ & $\begin{array}{r}457,62- \\
714,28\end{array}$ & $\begin{array}{r}488,89(467,8 \\
5-582,75)\end{array}$ & $\begin{array}{r}320- \\
654,76\end{array}$ \\
\hline $\begin{array}{l}\text { Incidência de } \\
\text { palavras } \\
\text { funcionais }\end{array}$ & $\begin{array}{r}357,84(288,21- \\
446,71)\end{array}$ & $\begin{array}{r}200- \\
577,46\end{array}$ & $\begin{array}{r}386,42(327,38- \\
446,73)\end{array}$ & $\begin{array}{r}285,71- \\
491,52\end{array}$ & $\begin{array}{r}402,29(354,4 \\
4-479,48)\end{array}$ & $\begin{array}{r}333,33- \\
680\end{array}$ \\
\hline $\begin{array}{l}\text { Incidência de } \\
\text { pronomes } \\
\text { pessoais }\end{array}$ & $0(0-50,90)$ & $0-84,51$ & $13,51(0-41,04)$ & $0-74,07$ & $\begin{array}{r}29,8(12,82- \\
67,93)\end{array}$ & $0-122,22$ \\
\hline $\begin{array}{l}\text { Relação Tipo por } \\
\text { Token }\end{array}$ & $0,51(0,42-0,56)$ & $0,34-0,77$ & $0,59(0,53-0,67)$ & $0,48-0,95$ & $\begin{array}{r}0,60(0,46- \\
0,76)\end{array}$ & $0,37-0,85$ \\
\hline Índice de Brunet & $\begin{array}{r}8,89(7,97- \\
10,39)\end{array}$ & $\begin{array}{l}5,55- \\
11,87\end{array}$ & $\begin{array}{r}9,29(7,04- \\
10,29)\end{array}$ & $6,27-10,59$ & $\begin{array}{r}8,74(7,84- \\
10,58)\end{array}$ & $7,81-12,35$ \\
\hline $\begin{array}{l}\text { Estatística de } \\
\text { Horoné }\end{array}$ & $\begin{array}{r}361,41(267,58- \\
433,53) \\
\end{array}$ & $\begin{array}{r}150,63- \\
751,46 \\
\end{array}$ & $\begin{array}{r}444,71(340,92- \\
466,52) \\
\end{array}$ & $\begin{array}{r}206,30- \\
527,55 \\
\end{array}$ & $\begin{array}{r}398,82(310,2 \\
1-609,13) \\
\end{array}$ & $\begin{array}{r}131,26- \\
759,25 \\
\end{array}$ \\
\hline
\end{tabular}

*Soma das proposições: Orientação, Problema, desenvolvimento e Desfecho **pares de letras "a, b, c" indicam diferenças entre os tempos de seguimento para cada variável estudada (teste não paramétrico Wilcoxon pareado) 
Entre o GA1, a comparação entre os parâmetros no início (até um mês após o AVC) e após 6 meses do AVC revelou que, no nível de macroestrutura, o número de proposições do bloco orientação e o total de proposições mostrou-se significativamente maior após 6 meses do AVC, e no bloco orientação, diferenças foram observadas também após 3 meses. Com relação à microestrutura, as medidas iniciais das variáveis sílabas por palavra de conteúdo, incidência de substantivos e incidência de palavras de conteúdo diferiram após 6 meses de intervenção. Já a variável incidência de palavras ausentes no dicionário apresentou valor significantemente menor após três meses de AVC.

Tabela 8 - Comparação entre índice de acertos (frequência proporcional de ocorrências) nos blocos da macroestrutura, na história Roubo dos Biscoitos, até um mês após o AVC.

\begin{tabular}{lccc}
\hline Variável 1 X Variável 2 & $\begin{array}{c}\text { Mediana } \\
(I Q) \text { variável 1 }\end{array}$ & $\begin{array}{c}\text { Mediana } \\
(I Q) \text { variável 2 }\end{array}$ & P \\
\hline Orientação x Problema & $0(0-0)$ & $0(0-0.16)$ & 0.158 \\
Orientação x Desenvolvimento & $0(0-0)$ & $0(0-0.5)$ & 0.083 \\
Orientação x Desfecho & $0(0-0)$ & $0(0-0)$ & -- \\
Orientação x Total de Proposições & $0(0-0)$ & $0(0-0.21)$ & 0.085 \\
Problema x Desenvolvimento & $0(0-0.16)$ & $0(0-0.5)$ & 0.566 \\
Problema x Desfecho & $0(0-0.16)$ & $0(0-0)$ & 0.158 \\
Problema x Total de Proposições & $0(0-0.16)$ & $0(0-0.21)$ & 0.566 \\
Desenvolvimento x Desfecho & $0(0-0.5)$ & $0(0-0)$ & 0.083 \\
Desenvolvimento x Total de Proposições & $0(0-0.5)$ & $0(0-0.21)$ & 0.085 \\
\hline
\end{tabular}

Não houve diferença entre a proporção de emprego de proposições nos blocos (orientação, desenvolvimento, problema, desfecho), até um mês após AVC. 
Tabela 9-Comparação entre índice de acertos (frequência proporcional de ocorrências) nos blocos da macroestrutura, na história Roubo dos Biscoitos 3 meses após o AVC.

\begin{tabular}{lrrr}
\hline Variável 1 X Variável 2 & $\begin{array}{r}\text { Mediana (IQ) } \\
\text { variável 1 }\end{array}$ & $\begin{array}{r}\text { Mediana (IQ) } \\
\text { variável 2 }\end{array}$ & P \\
\hline Orientação x Problema & $0(0-1)$ & $0(0-0.5)$ & 0.363 \\
Orientação x Desenvolvimento & $0(0-1)$ & $0.5(0.25-0.5)$ & 0.827 \\
Orientação x Desfecho & $0(0-1)$ & $0(0-0)$ & 0.445 \\
Orientação x Total de Proposições & $0(0-1)$ & $0.28(0.07-0.5)$ & 0.831 \\
Problema x Desenvolvimento & $0(0-0.5)$ & $0.5(0.25-0.5)$ & 0.286 \\
Problema x Desfecho & $0(0-0.5)$ & $0(0-0)$ & 0.682 \\
Problema x Total de Proposições & $0(0-0.5)$ & $0.28(0.07-0.5)$ & 0.088 \\
Desenvolvimento x Desfecho & $0.5(0.25-0.5)$ & $0(0-0)$ & 0.222 \\
Desenvolvimento x Total de Proposições & $0.5(0.25-0.5)$ & $0.28(0.07-0.5)$ & 0.356 \\
\hline
\end{tabular}

Não houve diferença entre os blocos da macroestrutura, na história do Roubo de Biscoitos, 3 meses após o AVC.

Tabela 10 - Comparação entre índice de acertos (frequência proporcional de ocorrências) nos blocos da macroestrutura, na história Roubo dos Biscoitos, 6 meses após o AVC.

\begin{tabular}{llll}
\hline Variável 1 X Variável 2 & $\begin{array}{l}\text { Mediana (IQ) } \\
\text { variável 1 }\end{array}$ & $\begin{array}{c}\text { Mediana } \\
\text { (IQ) variável 2 }\end{array}$ & $\mathbf{p}$ \\
\hline Orientação x Problema & $0(0-1)$ & $0.67(0-0.66)$ & 0.761 \\
Orientação x Desenvolvimento & $0(0-1)$ & $0.25(0-0.5)$ & 0.715 \\
Orientação x Desfecho & $0(0-1)$ & $0(0-0)$ & 0.083 \\
Orientação x Total de Proposições & $0(0-1)$ & $0.43(0-0.57)$ & 0.884 \\
Problema x Desenvolvimento & $0.67(0-0.66)$ & $0.25(0-0.5)$ & 0.191 \\
Problema x Desfecho & $0.67(0-0.66)$ & $0(0-0)$ & 0.027 \\
Problema x Total de Proposições & $0.67(0-0.66)$ & $0.43(0-0.57)$ & 0.029 \\
Desenvolvimento x Desfecho & $0.25(0-0.5)$ & $0(0-0)$ & 0.047 \\
Desenvolvimento x Total de Proposições & $0.25(0-0.5)$ & $0.43(0-0.57)$ & 0.561 \\
\hline
\end{tabular}


A tabela 10 mostra que o número de proposições empregadas no bloco desfecho mostrou-se significativamente menor que o empregado nos blocos problema e desenvolvimento.

Tabela 11 - Comparação da macroestrutura e microestrutura, entre afásicos de Broca e anômicos na história do Roubo dos Biscoitos.

\begin{tabular}{|c|c|c|c|c|c|}
\hline \multirow[t]{2}{*}{ Variável } & \multicolumn{2}{|c|}{ Broca(n=6) } & \multicolumn{2}{|c|}{ Anômica(n=2) } & \multirow[b]{2}{*}{$\rho^{* *}$} \\
\hline & $\begin{array}{l}\text { Mediana } \\
\text { (IQ) }\end{array}$ & Min-max & $\begin{array}{l}\text { Mediana*** }_{(I Q)} \\
\end{array}$ & Min-max & \\
\hline \multicolumn{6}{|l|}{ Macroestrutura } \\
\hline Orientação & $0,00(0-0)$ & $0-0$ & $0,00(0-0)$ & $0-0$ & -- \\
\hline Problema & $0,00(0-0)$ & $0-0,34$ & $0,33(0-0,67)$ & $0-0,67$ & 0,275 \\
\hline Desenvolvimento & $0(0-0,50)$ & $0-0,5$ & $0,25(0-0,5)$ & $0-0,5$ & 0,693 \\
\hline Desfecho & $0,00(0-0)$ & $0-0$ & $0,00(0-0)$ & $0-0$ & -- \\
\hline Total de proposições* & $0(0-0,14)$ & $0-0,29$ & $0,21(0-0,43)$ & $0-0,43$ & 0,445 \\
\hline \multicolumn{6}{|l|}{ Microestrutura } \\
\hline $\begin{array}{l}\text { Incidência de palavras } \\
\text { ausentes no dicionário }\end{array}$ & $110,00(75,00-150,00)$ & $0-230$ & $\begin{array}{r}134,00(129,00- \\
140,00)\end{array}$ & $\begin{array}{r}129,00- \\
140,00\end{array}$ & 0,505 \\
\hline $\begin{array}{l}\text { Índice de leiturabilidade } \\
\text { Flesch }\end{array}$ & $75,63(57,61-111,78)$ & $21,86-127,16$ & $61,91(40,26-83,56)$ & $40,25-83,56$ & 0,505 \\
\hline Quantidade de palavras & $31(18-71)$ & $10-86$ & $38(27-49)$ & $27-49$ & 1,000 \\
\hline $\begin{array}{l}\text { Sílabas por palavra de } \\
\text { conteúdo }\end{array}$ & $1,82(1,62-2,05)$ & $1,17-2,05$ & $2,29(2,21-2,36)$ & $2,21-2,36$ & 0,045 \\
\hline Incidência de verbos & $121,43(98,59-348,83)$ & $88,23-388,88$ & $\begin{array}{r}241,87(224,49- \\
259,25)\end{array}$ & $\begin{array}{r}224,49- \\
259,25\end{array}$ & 0,505 \\
\hline $\begin{array}{l}\text { Incidência de } \\
\text { substantivos }\end{array}$ & $235,46(169,01-300)$ & $0-323,52$ & $\begin{array}{r}190,85(122,45- \\
259,25)\end{array}$ & $\begin{array}{r}122,45- \\
259,25\end{array}$ & 0,738 \\
\hline Incidência de adjetivos & $0,00(0,00-36,00)$ & $0-300$ & $0,00(0,00-0,00)$ & $0,00-0,00$ & 0,382 \\
\hline Incidência de advérbios & $\begin{array}{r}161,08(100,00- \\
277,77)\end{array}$ & $28,17-285,71$ & $81,63(0,00-163,26)$ & $0-163,26$ & 0,317 \\
\hline $\begin{array}{l}\text { Incidência de } \\
\text { pronomes }\end{array}$ & $78,71(0,00-139,53)$ & $0-178,57$ & $81,63(0,00-163,26)$ & $0-163,26$ & 1,000 \\
\hline $\begin{array}{l}\text { Incidência de palavras } \\
\text { de conteúdo }\end{array}$ & $\begin{array}{r}676,36(617,65- \\
714,28)\end{array}$ & $295,77-800$ & $\begin{array}{r}514,36(510,20- \\
518,51)\end{array}$ & $\begin{array}{r}510,20- \\
518,52\end{array}$ & 0,182 \\
\hline $\begin{array}{l}\text { Incidência de palavras } \\
\text { funcionais }\end{array}$ & $\begin{array}{r}398,90(333,33- \\
502,29)\end{array}$ & $75,00-577,46$ & $\begin{array}{r}436,50(415,05- \\
493,58)\end{array}$ & $378,02-536$ & 0,182 \\
\hline $\begin{array}{l}\text { Incidência de } \\
\text { pronomes pessoais }\end{array}$ & $0(0-81,39)$ & $0-84,50$ & $10,20(0-20,41)$ & $0-20,41$ & 1,000 \\
\hline Relação Tipo por Token & $0,48(0,38-0,53)$ & $0,33-0,6$ & $0,65(0,53-0,77)$ & $0,53-0,77$ & 0,095 \\
\hline Índice de Brunet & $8,89(8,59-11,07)$ & $5,55-11,87$ & $8,53(7,35-9,71)$ & $7,35-9,71$ & 0,738 \\
\hline Estatística de Honoré & $\begin{array}{r}303,15(235,16- \\
416,53)\end{array}$ & $\begin{array}{r}150,63- \\
427,62\end{array}$ & $\begin{array}{r}595,46(439,45- \\
751,46)\end{array}$ & $\begin{array}{r}439,45- \\
751,47\end{array}$ & 0,045 \\
\hline
\end{tabular}


Na história Roubo dos Biscoitos, os afásicos anômicos apresentaram valores maiores nas métricas sílabas por palavra de conteúdo e estatística de Honoré em comparação aos valores dos afásicos de Broca.

As tabelas a seguir apresentam as análises do discurso nos níveis de macroestrutura e microestrutura do GA1, ao construir a história Cinderela. 
Tabela 12 - Comparação de discurso no nível de macroestrutura e microestrutura, segundo tempo de acompanhamento. História Cinderela $(n=8)$.

\begin{tabular}{|c|c|c|c|c|c|c|}
\hline \multirow[t]{2}{*}{ Variável } & \multicolumn{2}{|c|}{ Até 1 mêsa $(n=8)$} & \multicolumn{2}{|c|}{ Após 3 meses $^{\mathrm{b}}(\mathrm{n}=8)$} & \multicolumn{2}{|c|}{ Após $6 \operatorname{meses}^{c}(n=8)$} \\
\hline & $\begin{array}{l}\text { Mediana } \\
\text { (IQ) }\end{array}$ & $\begin{array}{l}\text { Min- } \\
\max \end{array}$ & $\begin{array}{l}\text { Mediana } \\
\text { (IQ) }\end{array}$ & $\begin{array}{l}\text { Min- } \\
\max \end{array}$ & $\begin{array}{l}\text { Mediana } \\
\text { (IQ) }\end{array}$ & Min-max \\
\hline \multicolumn{7}{|l|}{ Macroestrutura } \\
\hline Orientação & $0,14(0-0,14)^{a, c}$ & $0-0,28$ & $0,14(0-0,14)$ & $0-0,28$ & $0,21(0,07-0,36)$ & $0-0,43$ \\
\hline Problema & $0(0-0,20) a, c$ & $0-0,8$ & $0,1(0-0,2)$ & $0-0,40$ & $0,3(0-0,6)$ & $0-0,8$ \\
\hline Desenvolvimento & $0,07(0-0,21)^{a, c}$ & $0-0,64$ & $0,07(0-0,25)$ & $0-0,64$ & $0,18(0,03-0,36)$ & $0-0,71$ \\
\hline Desfecho & $0(0-0,5)$ & $0-1$ & $0,25(0-0,50)$ & $0-1$ & $0,25(0-0,5)$ & $0-1$ \\
\hline $\begin{array}{l}\text { Total de } \\
\text { proposições* }\end{array}$ & $0,07(0-0,25)^{a, c}$ & $0-0,53$ & $0,12(0-0,21)$ & $0-0,53$ & $0,23(0,03-0,41)$ & $0-0,64$ \\
\hline \multicolumn{7}{|l|}{ Microestrutura } \\
\hline $\begin{array}{l}\text { Incidência de } \\
\text { palavras ausentes } \\
\text { no dicionário }\end{array}$ & $\begin{array}{r}47,00(21,00- \\
83,00)\end{array}$ & $\begin{array}{r}0- \\
609,00\end{array}$ & $\begin{array}{r}70,87(62,17- \\
101,03)\end{array}$ & $\begin{array}{l}35,87- \\
122,97\end{array}$ & $\begin{array}{r}75,42(68,89- \\
87,90)\end{array}$ & $\begin{array}{l}64,52- \\
117,16\end{array}$ \\
\hline $\begin{array}{l}\text { Índice de } \\
\text { leiturabilidade } \\
\text { Flesch }\end{array}$ & $\begin{array}{r}-95,42(-288,36-- \\
16,22)^{a, b-a-a, c}\end{array}$ & $\begin{array}{r}-629,88- \\
83,42\end{array}$ & $\begin{array}{r}-134,48(- \\
251,35--108,55)\end{array}$ & $\begin{array}{r}337,48- \\
23,09\end{array}$ & $\begin{array}{r}-162,02(- \\
272,13-- \\
115,56)\end{array}$ & $\begin{array}{r}-362,88-- \\
25,75\end{array}$ \\
\hline $\begin{array}{l}\text { Quantidade de } \\
\text { palavras }\end{array}$ & $192(116-378)^{a, c}$ & $34-727$ & $\begin{array}{r}229,0(199,0- \\
351,0)\end{array}$ & $69-434$ & $262(196-373)$ & $124-464$ \\
\hline $\begin{array}{l}\text { Sílabas por palavra } \\
\text { de conteúdo }\end{array}$ & $2,04(1,89-2,22)$ & $\begin{array}{r}1,37- \\
2,78\end{array}$ & $2,09(1,98-2,28)$ & $\begin{array}{r}1,76- \\
2,59\end{array}$ & $2,12(1,9-2,38)$ & $1,90-2,7$ \\
\hline $\begin{array}{l}\text { Incidência de } \\
\text { verbos }\end{array}$ & $\begin{array}{r}206,59(146,85- \\
233,83)\end{array}$ & $\begin{array}{r}25- \\
244,89\end{array}$ & $\begin{array}{r}213,27(145,69- \\
232,38)\end{array}$ & $\begin{array}{r}14,49- \\
246,51\end{array}$ & $\begin{array}{r}215,40(173,82- \\
242,33)\end{array}$ & $\begin{array}{r}8,06- \\
246,91\end{array}$ \\
\hline $\begin{array}{l}\text { Incidência de } \\
\text { substantivos }\end{array}$ & $\begin{array}{r}187,05(148,94- \\
280)\end{array}$ & $\begin{array}{r}42,25- \\
562,5\end{array}$ & $\begin{array}{r}216,46(164,06- \\
281,25)\end{array}$ & $\begin{array}{r}101,85- \\
376,81\end{array}$ & $\begin{array}{r}208,92(172,60- \\
279,15)\end{array}$ & $\begin{array}{r}141,97- \\
395,16\end{array}$ \\
\hline $\begin{array}{l}\text { Incidência de } \\
\text { adjetivos }\end{array}$ & $18,52(4,40-29,41$ & $0-337,5$ & $\begin{array}{r}6,47(1,84- \\
18,23)\end{array}$ & $0-36,69$ & $\begin{array}{r}6,80(3,53- \\
12,39)\end{array}$ & $0-15,08$ \\
\hline $\begin{array}{l}\text { Incidência de } \\
\text { advérbios }\end{array}$ & $\begin{array}{r}77,59(49,75- \\
140,27)\end{array}$ & $\begin{array}{r}0 \\
229,16\end{array}$ & $\begin{array}{r}109,46(47,32- \\
143,38)\end{array}$ & $\begin{array}{r}41,67- \\
217,39\end{array}$ & $\begin{array}{r}60,98(53,86- \\
110,89)\end{array}$ & $\begin{array}{r}8,06- \\
172,41\end{array}$ \\
\hline $\begin{array}{l}\text { Incidência de } \\
\text { pronomes }\end{array}$ & $\begin{array}{r}145,07(109,45- \\
193,12)\end{array}$ & $\begin{array}{r}0- \\
285,71\end{array}$ & $\begin{array}{r}148,68(99,18- \\
172,66)\end{array}$ & $\begin{array}{r}0- \\
256,94\end{array}$ & $\begin{array}{r}133,47(89,44- \\
193,69)\end{array}$ & $\begin{array}{l}16,13- \\
212,96\end{array}$ \\
\hline $\begin{array}{l}\text { Incidência de } \\
\text { palavras de } \\
\text { conteúdo }\end{array}$ & $\begin{array}{r}541,96(451,83- \\
575,54)\end{array}$ & $\begin{array}{r}428,57- \\
925\end{array}$ & $\begin{array}{r}513,60(473,74- \\
588,28)\end{array}$ & $\begin{array}{r}435,18- \\
608,69\end{array}$ & $\begin{array}{r}519,59(451,42- \\
553,98)\end{array}$ & $\begin{array}{r}411,29- \\
607,75\end{array}$ \\
\hline $\begin{array}{l}\text { Incidência de } \\
\text { palavras } \\
\text { funcionais }\end{array}$ & $\begin{array}{r}425,53(381,29- \\
502,29)\end{array}$ & $\begin{array}{r}75 \\
549,29\end{array}$ & $\begin{array}{r}459,69(393,07- \\
505,75)\end{array}$ & $\begin{array}{r}377,88- \\
541,66\end{array}$ & $\begin{array}{r}454,31(387,93- \\
492,35)\end{array}$ & $\begin{array}{r}312,5- \\
588,71\end{array}$ \\
\hline $\begin{array}{l}\text { Incidência de } \\
\text { pronomes } \\
\text { pessoais }\end{array}$ & $\begin{array}{r}68,96(29,82- \\
94,42)\end{array}$ & $\begin{array}{r}0- \\
167,42\end{array}$ & $\begin{array}{r}82,53(36,47- \\
127,56)\end{array}$ & $\begin{array}{r}0- \\
173,61\end{array}$ & $\begin{array}{r}83,39(47,09- \\
104,59)\end{array}$ & $0-170,63$ \\
\hline $\begin{array}{l}\text { Relação Tipo por } \\
\text { Token }\end{array}$ & $0,39(0,27-0,47)$ & $\begin{array}{r}0,11- \\
0,58\end{array}$ & $0,33(0,28-0,38)$ & $\begin{array}{r}0,19- \\
0,45\end{array}$ & $0,31(0,28-0,43)$ & $0,18-0,49$ \\
\hline Índice de Brunet & $\begin{array}{r}12,99(11,64- \\
15,48)\end{array}$ & $\begin{array}{r}8,59- \\
21,10\end{array}$ & $\begin{array}{r}14,46(13,31- \\
15,39)\end{array}$ & $\begin{array}{r}12,54- \\
16,63\end{array}$ & $\begin{array}{r}14,93(12,87- \\
15,49\end{array}$ & $\begin{array}{r}11,79- \\
18,07\end{array}$ \\
\hline $\begin{array}{l}\text { Estatística de } \\
\text { Honoré }\end{array}$ & $\begin{array}{r}528,10(429,58- \\
585,53)\end{array}$ & $\begin{array}{r}219,84- \\
806,18\end{array}$ & $\begin{array}{r}556,45(501,59- \\
656,72)\end{array}$ & $\begin{array}{r}239,05- \\
678,52\end{array}$ & $\begin{array}{r}575,95(481,33- \\
638,91)\end{array}$ & $\begin{array}{r}383,79- \\
706,02\end{array}$ \\
\hline
\end{tabular}

* pares de letras "a, b, c" indicam diferenças entre os tempos de seguimento para cada variável estudada (teste não paramétrico Wilcoxon pareado) 
Todas as variáveis do nível de macroestrutura após 6 meses de acompanhamento, com exceção do desfecho, diferiram em relação aos 3 meses. No nível da microestrutura, somente a variável índice de leiturabilidade de Flesch e quantidade de palavras apresentaram diferenças após 3 e 6 meses do AVC.

Tabela 13 - Comparação entre índice de acertos (frequência proporcional de ocorrências) nos blocos da macroestrutura, na história da Cinderela, até um mês após o AVC.

\begin{tabular}{lccc}
\hline Variável 1 X Variável 2 & $\begin{array}{c}\text { Mediana } \\
(\mathbf{I Q}) \\
\text { variável 1 }\end{array}$ & $\begin{array}{c}\text { Mediana } \\
(\mathbf{I Q}) \\
\text { variável 2 }\end{array}$ & $\mathbf{P}$ \\
\hline Orientação x Problema & $0,14(0-0,14)$ & $0(0-0,60)$ & 0,190 \\
Orientação x Desenvolvimento & $0,14(0-0,14)$ & $0,14(0-0,36)$ & 0,190 \\
Orientação x Desfecho & $0,14(0-0,14)$ & $0,5(0-0,5)$ & $\mathbf{0 , 0 3 2}$ \\
Orientação x Total de Proposições & $0,14(0-0,14)$ & $0,14(0,04-0,36)$ & $\mathbf{0 , 0 3 9}$ \\
Problema x Desenvolvimento & $0(0-0,60)$ & $0,14(0-0,36)$ & 1,00 \\
Problema x Desfecho & $0(0-0,60)$ & $0,5(0-0,5)$ & 0,392 \\
Problema x Total de Proposições & $0(0-0,60)$ & $0,14(0,036-0,36)$ & 0,909 \\
Desenvolvimento x Desfecho & $0,14(0-0,36)$ & $0,5(0-0,5)$ & 0,233 \\
Desenvolvimento x Total de Proposições & $0,14(0-0,36)$ & $0,14(0,036-0,36)$ & 0,161 \\
\hline
\end{tabular}

Ao comparar os valores medianos do índice de acertos entre as variáveis do nível macroestrutural até um mês após AVC, nota-se que o bloco orientação difere do desfecho quanto do total de proposições, sendo a orientação significativamente maior que o desfecho e menor que o total de proposições. 
Tabela 14 - Comparação entre índice de acertos (frequência proporcional de ocorrências) nos blocos da macroestrutura, na história da Cinderela, 3 meses após o AVC.

\begin{tabular}{lllr}
\hline Variável 1 X Variável 2 & $\begin{array}{l}\text { Mediana (IQ) } \\
\text { variável 1 (IQ) }\end{array}$ & $\begin{array}{c}\text { Mediana (IQ) } \\
\text { variável 2 (IQQ) }\end{array}$ & p \\
\hline Orientação x Problema & $0,14(0-0,14)$ & $0,1(0-0,2)$ & 0,307 \\
Orientação x Desenvolvimento & $0,14(0-0,14)$ & $0,07(0-0,25)$ & 0,323 \\
Orientação x Desfecho & $0,14(0-0,14)$ & $0,25(0-0,5)$ & 0,108 \\
Orientação x Total de Proposições & $0,14(0-0,14)$ & $0,12(0-0,21)$ & 0,191 \\
Problema x Desenvolvimento & $0,1(0-0,2)$ & $0,07(0-0,25)$ & 0,468 \\
Problema x Desfecho & $0,1(0-0,2)$ & $0,25(0-0,5)$ & 0,110 \\
Problema x Total de Proposições & $0,1(0-0,2)$ & $0,12(0-0,21)$ & 0,468 \\
Desenvolvimento x Desfecho & $0,07(0-0,25)$ & $0,25(0-0,5)$ & $\mathbf{0 , 0 4 8}$ \\
Desenvolvimento x Total de Proposições & $0,07(0-0,25)$ & $0,12(0-0,21)$ & 0,611 \\
\hline
\end{tabular}

A comparação entre os valores medianos do índice de acertos entre as variáveis do nível macroestrutural após 3 meses do AVC indicou diferenças significantes apenas entre as blocos desenvolvimento e desfecho, sendo o desfecho significativamente maior.

Tabela 15 - Comparação entre índice de acertos (frequência proporcional de ocorrências) nos blocos da macroestrutura, na história da Cinderela, 6 meses após o AVC.

\begin{tabular}{|c|c|c|c|}
\hline Variável 1 X Variável 2 & $\begin{array}{c}\text { Mediana } \\
(\mathrm{IQ}) \\
\text { variável } 1(\mathrm{IQ}) \\
\end{array}$ & $\begin{array}{c}\text { Mediana } \\
\text { (IQ) variável } 2\end{array}$ & $\mathbf{P}$ \\
\hline Orientação x Problema & $0,21(0,07-0,36)$ & $0,3(0-0,6)$ & 0,178 \\
\hline Orientação x Desenvolvimento & $0,21(0,07-0,36)$ & $0,18(0,03-0,36)$ & 1,000 \\
\hline Orientação x Desfecho & $0,21(0,07-0,36)$ & $0,25(0-0,5)$ & 0,356 \\
\hline Orientação x Total de Proposições & $0,21(0,07-0,36)$ & $0,23(0,03-0,41)$ & 0,523 \\
\hline Problema x Desenvolvimento & $0,3(0-0,6)$ & $0,18(0,03-0,36)$ & 0,287 \\
\hline Problema x Desfecho & $0,3(0-0,6)$ & $0,25(0-0,5)$ & 0,771 \\
\hline Problema x Total de Proposições & $0,3(0-0,6)$ & $0,23(0,03-0,41)$ & 0,523 \\
\hline Desenvolvimento x Desfecho & $0,18(0,03-0,36)$ & $0,25(0-0,5)$ & 0,435 \\
\hline Desenvolvimento x Total de Proposições & $0,18(0,03-0,36)$ & $0,23(0,03-0,41)$ & 0,363 \\
\hline
\end{tabular}


Não houve diferença na proporção de acertos entre os índices após 6 meses de AVC.

Tabela 16 - Comparação dos valores medianos do parâmetro macroestrutural entre os afásicos $(n=8)$, segundo o tipo de história até 1 mês, após 3 meses e após 6 meses do AVC.

\begin{tabular}{|c|c|c|c|c|c|c|}
\hline \multirow[t]{3}{*}{ Variável } & \multicolumn{2}{|c|}{ Até 1 mês } & \multicolumn{2}{|c|}{3 meses } & \multicolumn{2}{|c|}{6 meses } \\
\hline & $\begin{array}{l}\text { Biscoito } \\
\text { (a) }\end{array}$ & Cinderela ${ }^{(b)}$ & Biscoito (a) & Cinderela (b) & Biscoito (a) & Cinderela (b) \\
\hline & $\begin{array}{l}\text { Mediana } \\
(I Q)\end{array}$ & Mediana (IQ) & Mediana (IQ) & Mediana (IQ) & Mediana (IQ) & Mediana (IQ) \\
\hline Orientação & 0 & 0 & 0 & 0,14 & 0 & 0,21 \\
\hline (acertos/total) & $(0 ; 0)$ & $(0 ; 0,14)$ & $(0 ; 1,0)$ & $(0 ; 0,14)$ & $(0 ; 1,0)$ & $(0,07 ; 0,36)$ \\
\hline Problema & 0 & $0(0 ; 0)$ & 0 & 0,10 & 0,67 & 0,30 \\
\hline (acertos/total) & $(0 ; 0,17)$ & & $(0 ; 0,50)$ & $(0 ; 0,20)$ & $(0 ; 0,67)$ & $(0 ; 0,60)$ \\
\hline Desenvolvimento & 0 & 0 & 0,50 & 0,07 & 0,25 & 0,18 \\
\hline (acertos/total) & $(0 ; 0,50)$ & $(0 ; 0,04)$ & $(0,25 ; 0,50)$ & $(0 ; 0,25)$ & $(0 ; 0,50)$ & $(0,03 ; 0,35)$ \\
\hline Desfecho & 0 & 0 & 0 & 0,25 & 0 & 0,25 \\
\hline (acertos/total) & $(0 ; 0)$ & $(0 ; 0,25)$ & $(0 ; 0)$ & $(0 ; 0,50)$ & $(0 ; 0)$ & $(0 ; 0,50)(a, b)$ \\
\hline Total de & 0 & 0,01 & 0,28 & 0,12 & 0,43 & 0,23 \\
\hline $\begin{array}{l}\text { proposições } \\
\text { (acertos/total)* }^{*}\end{array}$ & $(0 ; 0,21)$ & $(0 ; 0,05)$ & $(0,07 ; 0,50)$ & $(0 ; 0,21)$ & $(0 ; 0,57)$ & $(0,03 ; 0,41)$ \\
\hline
\end{tabular}


Tabela 17 - Comparação dos valores medianos do parâmetro microestrutural entre os afásicos $(n=8)$, segundo o tipo de história até 1 mês, após 3 meses e após 6 meses do AVC.

\begin{tabular}{|c|c|c|c|c|c|c|}
\hline \multirow[t]{3}{*}{ Variável } & \multicolumn{2}{|c|}{ Até 1 mês } & \multicolumn{2}{|c|}{3 meses } & \multicolumn{2}{|c|}{6 meses } \\
\hline & $\begin{array}{l}\text { Biscoito } \\
\text { (a) }\end{array}$ & Cinderela ${ }^{(b)}$ & Biscoito (a) & Cinderela ${ }^{(b)}$ & Biscoito (a) & Cinderela $^{(b)}$ \\
\hline & $\begin{array}{l}\text { Mediana } \\
\text { (IQ) }\end{array}$ & Mediana (IQ) & Mediana (IQ) & Mediana (IQ) & Mediana (IQ) & Mediana (IQ) \\
\hline $\begin{array}{l}\text { Incidência de } \\
\text { palavras ausentes } \\
\text { no dicionário }\end{array}$ & $\begin{array}{r}126,24 \\
(86,02 ; 14 \\
5,17)\end{array}$ & $\begin{array}{r}57,19 \\
(35,89 ; 85,59)\end{array}$ & $\begin{array}{r}76,56 \\
(30,42 ; 124,52 \\
)\end{array}$ & $\begin{array}{r}70,87 \\
(62,17 ; \\
101,03)\end{array}$ & $\begin{array}{r}95,23 \\
(81,35 ; \\
113,51)\end{array}$ & $\begin{array}{r}75,42 \\
(68,89 ; 87,90)\end{array}$ \\
\hline $\begin{array}{l}\text { Índice de } \\
\text { leiturabilidade } \\
\text { Flesch }\end{array}$ & $\begin{array}{r}74,94 \\
(48,93 ; 98 \\
36)\end{array}$ & $\begin{array}{r}-87,10 \\
(-106,37 ;- \\
19,09)(a, b)\end{array}$ & $\begin{array}{r}64,98 \\
(43,09 ; 70,82)\end{array}$ & $\begin{array}{r}-134,48 \\
(-251,35 ;- \\
108,55)^{(a, b)}\end{array}$ & $\begin{array}{r}59,95 \\
(14,29 ; 74,66)\end{array}$ & $\begin{array}{r}-162,02 \\
(-272,14 ;- \\
115,57)^{(a, b)}\end{array}$ \\
\hline $\begin{array}{l}\text { Quantidade de } \\
\text { palavras }\end{array}$ & $\begin{array}{r}31,00 \\
(22,50 ; 60 \\
00)\end{array}$ & $\begin{array}{r}190,00 \\
(102,50 ; 211,0 \\
0)^{(a, b)}\end{array}$ & $\begin{array}{r}49,00 \\
(24,50 ; 61,50)\end{array}$ & $\begin{array}{r}229 \\
(199,50,351,5 \\
\text { 0) }(a, b)\end{array}$ & $\begin{array}{r}36,50 \\
(33,50 ; 85,00)\end{array}$ & $\begin{array}{r}262,00 \\
(196,00 ; 373,0 \\
0)(a, b)\end{array}$ \\
\hline $\begin{array}{l}\text { Sílabas por palavra } \\
\text { de conteúdo }\end{array}$ & $\begin{array}{r}1,93 \\
(1,71 ; 2,13 \\
)\end{array}$ & $\begin{array}{r}2,00 \\
(1,80 ; 2,10)\end{array}$ & $\begin{array}{r}2,12 \\
(1,89 ; 2,27)\end{array}$ & $\begin{array}{r}2,08 \\
(1,98 ; 2,27)\end{array}$ & $\begin{array}{r}2,11 \\
(2,01 ; 2,45)\end{array}$ & $\begin{array}{r}2,12 \\
(1,93 ; 2,38)\end{array}$ \\
\hline $\begin{array}{l}\text { Incidência de } \\
\text { verbos }\end{array}$ & $\begin{array}{r}183,67 \\
(99,30 ; 30 \\
4,05)\end{array}$ & $\begin{array}{r}198,16 \\
(114,43 ; 222,5 \\
5)\end{array}$ & $\begin{array}{r}208,49 \\
(163,03 ; 269,1 \\
7)\end{array}$ & $\begin{array}{r}213,27 \\
(145,70 ; 232,3 \\
8)\end{array}$ & $\begin{array}{r}174,24 \\
(60,69 ; 221,99 \\
)\end{array}$ & $\begin{array}{r}215,41 \\
(173,82 ; 242,3 \\
3)\end{array}$ \\
\hline $\begin{array}{l}\text { Incidência de } \\
\text { substantivos }\end{array}$ & $\begin{array}{r}235,46 \\
(145,73 ; 2 \\
79,63)\end{array}$ & $\begin{array}{r}166,51 \\
(131,74 ; 283,3 \\
5)\end{array}$ & $\begin{array}{r}224,75 \\
(178,50 ; 264,8 \\
8)\end{array}$ & $\begin{array}{r}216,46 \\
(164,06 ; 281,2 \\
5)\end{array}$ & $\begin{array}{r}292,19 \\
(272,35 ; 321,4 \\
3)\end{array}$ & $\begin{array}{r}208,92 \\
(172,61 ; 279,1 \\
5)\end{array}$ \\
\hline $\begin{array}{l}\text { Incidência de } \\
\text { adjetivos }\end{array}$ & $\begin{array}{r}0 \\
(0 ; 17,85)\end{array}$ & $\begin{array}{r}10,89 \\
(0 ; 22,06)\end{array}$ & $\begin{array}{r}0 \\
(0 ; 18,66)\end{array}$ & $\begin{array}{r}6,47 \\
(1,84 ; 18,23)\end{array}$ & $\begin{array}{r}0 \\
(0 ; 0)\end{array}$ & $\begin{array}{r}6,80 \\
(3,52 ; 12,39) \\
(a, b)\end{array}$ \\
\hline $\begin{array}{l}\text { Incidência de } \\
\text { advérbios }\end{array}$ & $\begin{array}{r}139,77 \\
(64,08 ; 24 \\
1,83)\end{array}$ & $\begin{array}{r}103,39 \\
(32,87 ; 177,59 \\
)\end{array}$ & $\begin{array}{r}113,31 \\
(46,16 ; 188,46 \\
)\end{array}$ & $\begin{array}{r}109,46 \\
(46,16 ; 156,62 \\
)\end{array}$ & $\begin{array}{r}71,00 \\
(25,64 ; 97,61)\end{array}$ & $\begin{array}{r}60,97 \\
(53,86 ; 110,89\end{array}$ \\
\hline $\begin{array}{l}\text { Incidência de } \\
\text { pronomes }\end{array}$ & $\begin{array}{r}78,70 \\
(0 ; 151,40)\end{array}$ & $\begin{array}{r}173,48 \\
(94,86 ; 209,96 \\
)\end{array}$ & $\begin{array}{r}60,68 \\
(23,44 ; 129,88 \\
)\end{array}$ & $\begin{array}{r}148,69 \\
(99,17 ; 172,67 \\
)\end{array}$ & $\begin{array}{r}55,05 \\
(32,59 ; 154,06 \\
)\end{array}$ & $\begin{array}{r}133,47 \\
(89,44 ; 193,69\end{array}$ \\
\hline $\begin{array}{l}\text { Incidência de } \\
\text { palavras de } \\
\text { conteúdo }\end{array}$ & $\begin{array}{r}642,16 \\
(514,36 ; 7 \\
00,17)\end{array}$ & $\begin{array}{r}464,60 \\
(451,27 ; 576,4 \\
1)\end{array}$ & $\begin{array}{r}549,75 \\
(500,00 ; 654,7 \\
6)\end{array}$ & $\begin{array}{r}513,60 \\
(473,74 ; 588,2 \\
8)\end{array}$ & $\begin{array}{r}488,89 \\
(467,85 ; 582,7 \\
5)\end{array}$ & $\begin{array}{r}519,59 \\
(451,42 ; 553,9 \\
8)\end{array}$ \\
\hline $\begin{array}{l}\text { Incidência de } \\
\text { palavras } \\
\text { funcionais }\end{array}$ & $\begin{array}{r}357,84 \\
(288,21 ; 4 \\
46,71)\end{array}$ & $\begin{array}{r}497,42 \\
(371,12 ; 530,4 \\
4)\end{array}$ & $\begin{array}{r}386,42 \\
(327,38 ; 446,7 \\
3)\end{array}$ & $\begin{array}{r}459,69 \\
(393,07 ; 505,7 \\
5)\end{array}$ & $\begin{array}{r}402,28 \\
(354,44 ; 479,4 \\
8)\end{array}$ & $\begin{array}{r}454,31 \\
(387,93 ; 492,3 \\
5)\end{array}$ \\
\hline $\begin{array}{l}\text { Incidência de } \\
\text { pronomes } \\
\text { pessoais }\end{array}$ & $\begin{array}{r}0 \\
(0 ; 50,90)\end{array}$ & $\begin{array}{r}42,90 \\
(14,85 ; 85,01)\end{array}$ & $\begin{array}{r}13,51 \\
(0 ; 41,05)\end{array}$ & $\begin{array}{r}82,53 \\
(36,47 ; 127,57 \\
)^{(a, b)}\end{array}$ & $\begin{array}{r}29,86 \\
(12,82 ; 67,92)\end{array}$ & $\begin{array}{r}83,39 \\
(47,09 ; 104,60\end{array}$ \\
\hline $\begin{array}{l}\text { Relação Tipo por } \\
\text { Token }\end{array}$ & $\begin{array}{r}0,51 \\
(0,42 ; 0,56 \\
)\end{array}$ & $\begin{array}{r}0,28 \\
(0,23 ; 0,42) \\
(a, b)\end{array}$ & $\begin{array}{r}0,59 \\
(0,53 ; 0,67)\end{array}$ & $\begin{array}{r}0,33 \\
(0,28 ; 0,38)^{(a, b)}\end{array}$ & $\begin{array}{r}0,60 \\
(0,45 ; 0,76)\end{array}$ & $\begin{array}{r}0,31 \\
(0,28 ; 0,42)^{(a, b)}\end{array}$ \\
\hline Índice de Brunet & $\begin{array}{r}8,90 \\
(7,96 ; 10,3 \\
9)\end{array}$ & $\begin{array}{r}14,41 \\
(12,54 ; 17,17) \\
(a, b)\end{array}$ & $\begin{array}{r}9,28 \\
(7,04 ; 10,29)\end{array}$ & $\begin{array}{r}14,46 \\
(13,31 ; 15,40) \\
(a, b)\end{array}$ & $\begin{array}{r}8,74 \\
(7,83 ; 10,57)\end{array}$ & $\begin{array}{r}14,93 \\
(12,87 ; 15,49) \\
(a, b)\end{array}$ \\
\hline $\begin{array}{l}\text { Estatística de } \\
\text { Honoré }\end{array}$ & $\begin{array}{r}361,41 \\
(267,58 ; 4 \\
33,54)\end{array}$ & $\begin{array}{r}509,78 \\
(389,71 ; 562,7 \\
0)\end{array}$ & $\begin{array}{r}444,71 \\
(340,92 ; 466,5 \\
2)\end{array}$ & $\begin{array}{r}556,45 \\
(501,59 ; 656,7 \\
2)^{(a, b)}\end{array}$ & $\begin{array}{r}398,83 \\
(310,22 ; 609,1 \\
4)\end{array}$ & $\begin{array}{r}575,95 \\
(481,33 ; 638,9 \\
2)\end{array}$ \\
\hline
\end{tabular}


*Soma dos índices em cada proposição (Orientação + Problema + desenvolvimento + Desfecho); **pares de letras " $\mathrm{a}, \mathrm{b}$ indicam diferenças do parâmetro entre as histórias (os valores medianos foram comparados por meio do teste não paramétrico de ManWhitney).

As tabelas 16 e 17 comparam os parâmetros de análise micro e macroestruturais segundo o tipo de história, em cada período (até 1 mês, 3 e 6 meses após o AVC. Nota-se que no nível macroestrutural diferenças entre as histórias só foram observadas no bloco desfecho, após 6 meses do AVC. Quanto ao aspecto microestrutural, diferenças significantes entre as histórias em todos os tempos avaliados (até 1 mês, 3 meses e 6 meses) foram observadas para os parâmetros: índice de leiturabilidade de Flesch, quantidade de palavras, relação Tipo por Token e índice de Brunet, já após 3 meses do AVC. Além destas variáveis, o parâmetro índice de pronomes pessoais também diferiu entre as histórias e aos 6 meses o parâmetro incidência de adjetivos também diferiu entre as histórias. 


\section{DISCUSSÃO}

O presente estudo teve como objetivo verificar se existem diferenças entre o desempenho dos grupos de sujeitos com afasia de Broca, afasia anômica e cognitivamente sadios, na tarefa de produção de narrativas, explorando tecnologias computadorizadas de análise de discursos, buscando marcadores de desempenho, que caracterizassem diferenças em aspectos macro e micro estruturais de narrativas. Além disso, teve como objetivo explorar o discurso como indicador de evolução da afasia e analisar a contribuição do SPECT para verificação de evolução da afasia. Para tanto, foram realizadas duas análises (estudo 1 e estudo 2), com grupos diferentes.

Este capítulo será dividido para facilitar a discussão dos dados e da literatura: caracterização da amostra, análise do estudo 1, análise do estudo 2 e limitações do estudo.

\subsection{Caracterização da amostra}

Em relação à caracterização da amostra, verificou-se que o GA2 apresenta idade e escolaridade significativamente menores que o GC. O pareamento dos grupos ficou comprometido pelo fato de o GA2 ter sido constituído por indivíduos com idade menor com 60 anos, o que desafiou nossa expectativa inicial. Além disso, também houve dificuldade de emparelhamento da escolaridade, já que o GA2 foi constituído por pessoas com maior restrição de acesso à instrução forma. Entre os sujeitos afásicos proveniente de hospital público predomina escolaridade básica ou rudimentar enquanto no grupo controle oriundo da comunidade há maior diversidade de nível de escolaridade, 
o que dificultou o emparelhamento. Porém foi possível constituir grupos com número equilibrado de tipos de afasias no GA2.

O não pareamento das amostras compromete a análise da gravidade das alterações no grupo afásico, estimada pela referência ao grupo de indivíduos sadios. O fato do grupo GA2 ter sido comparado com o GC, constituído por indivíduos com maior escolaridade penaliza os sujeitos afásicos, acentuando as diferenças de desempenho. Assim sendo, é possível que as diferenças no desempenho sejam menores do que o observado.

Houve dificuldade em recrutar indivíduos para o GA1, notada pelo número reduzido de sujeitos. Isso porque os sujeitos do GA1 deveriam aderir a todas as etapas do estudo, assumindo compromisso de participação por no mínimo seis meses. Foram triados 118 pacientes com AVC agudo no prontosocorro do HCFMUSP, sendo que 111 foram excluídos. A exclusão se deve aos seguintes fatores: 45 não apresentavam lesão vascular em hemisfério esquerdo; 46 apresentavam lesão vascular em hemisfério esquerdo, porém não apresentavam afasia ou apresentavam afasia de outro tipo; 20 apresentavam lesão vascular em hemisfério esquerdo, com diagnóstico de afasia de Broca ou anômica, porém não concluíram todas as etapas de avaliação. Houve ainda abandono de sujeitos pelos seguintes motivos: dificuldade de locomoção até o hospital, transferências para outros hospitais, não realização do SPECT, falta à consulta neurológica e por fim, alguns sujeitos não conheciam a história da Cinderela. Devido à dificuldade de recrutamento de sujeitos, não foi possível o balanceamento entre os tipos de afasia, o que levou a um maior contingente de afásicos de Broca. 
Na população com AVC atendida no Ponto Socorro do HCFMUSP predominam acometimentos graves, multi-comorbidades e riscos iminentes de morte. Como previsto nessa fase aguda, muitos dos casos apresentaram afasia global, o que impediu a inclusão no estudo (critério tipo de afasia).

Em estudos sobre discurso obtido a partir da história da Cinderela, quando se observa o número de participantes observa-se que as amostras são pequenas, com média de 8 a 10 participantes (Bird, Fraklin,1996, FaroqiShah, Thompson, 2007, Andreetta et al. 2012. O estudo de Rochon se destaca com 29 participantes afásicos. Em alguns estudos compara-se grupo controle com um grupo de afásicos e em outros compara-se afásicos de diferentes tipos. Encontra-se ainda expressivo número de estudos de casos, como o de Stark (2010). Em termos gerais, predominam sujeitos classificados como não fluentes.

No contexto dos estudos citados, podemos reconhecer que o nosso foi similar às pesquisas, tanto no que diz respeito ao tamanho da amostra, tipos de afasia e que, apesar da amostra reduzida foi possível obter dados analisáveis do ponto de vista computacional, um dos nossos objetivos.

\subsection{Análise do estudo 1}

A primeira análise, estudo 1, teve como alvo duas comparações: 1 . comparar os sujeitos do GC e do GA2 em termos do desempenho de aspectos de micro e macroestrutura produzidas na narrativa da história da Cinderela. 2. verificar se há diferenças entre os sujeitos afásicos de Broca e anômicos no GA2. 
Com relação à macroestrutura, o GA2 se diferenciou significativamente do GC, em relação ao número de proposições. Observa-se que os indivíduos cognitivamente sadios apresentaram proporção significativamente maior de proposições emitidas, em todos os parâmetros macroestruturais eleitos para 0 estudo, nos blocos orientação, problema e desfecho. O mesmo não ocorreu no bloco de proposições relacionadas ao desenvolvimento, em que houve número significativamente maior de emissões entre os afásicos. Isso pode ser justificado pelo fato de o bloco desenvolvimento apresentar "pacotes" detalhados de sequências de ações, nem sempre essenciais à composição da macroestrutura. Daí o fato de haver maior número de omissões de proposições, mesmo entre os indivíduos sadios, relacionadas ao bloco desenvolvimento. Em outras palavras havia maior número de pranchas relacionadas ao bloco desenvolvimento, o que pode ter induzido descrições das mesmas.

Podemos, então, interpretar que o significado global e essencial do texto e a estrutura narrativa apresentaram-se em maior conformidade com a expectativa, em sujeitos cognitivamente sadios do que em sujeitos afásicos, sendo o número total de proposições capaz de diferenciar os grupos.

Quanto à microestrutura, nos 15 parâmetros avaliados, sete indicaram diferenças significativas entre os grupos: incidência de palavras ausentes no dicionário, índice de leiturabilidade Flesch, quantidade de palavras, sílabas por palavra de conteúdo, índice de verbos, relação Tipo por Token, estatística de Honoré. Todas essas métricas foram significantemente maiores no GC, com exceção dos parâmetros incidência de palavras ausentes no dicionário e índice de leiturabilidade Flesch. Isso mostrou que os sujeitos do GC apresentaram 
maior número de palavras reais, maior complexidade textual e lexical e maior número de verbos, sendo estas métricas capazes de diferenciar os grupos.

O estudo de Rochon et al. (2000) também utilizou o discurso produzido a partir da história da Cinderela e constatou que sujeitos afásicos apresentaram significativa restrição da complexidade textual e gramatical.

A comparação entre os parâmetros de análise, no nível macro e micro estrutural, na história Cinderela indicou que no GA2, sujeitos afásicos anômicos apresentaram proporção significantemente maior de acertos no bloco desenvolvimento e total de proposições (nível macro), bem como maiores valores medianos para as variáveis sílabas por palavra de conteúdo e relação Tipo por Token entre afásicos de Broca. Já o parâmetro incidência de palavras ausentes no dicionário mostrou-se significativamente menor entre os afásicos anômicos quando comparados com os afásicos de Broca. Assim, constata-se que os afásicos anômicos realizaram a narrativa com melhor organização textual global, do que os afásicos de Broca, e apresentaram maior complexidade textual e número de palavras. Além disso, em nosso estudo, não houve diferenças entre incidência de substantivos e incidência de verbos entre os afásicos anômicos e afásicos de Broca, contrariando a expectativa e os resultados encontrados em outros estudos. Esperava-se que os afásicos de Broca apresentassem índice de substantivos maior do que os afásicos anômicos e estes últimos apresentassem índice de verbos maior do que os afásicos de Broca.

Segundo a literatura, nos indivíduos com afasia de Broca, espera-se que o agramatismo e apraxia de fala, associados à anomia comprometam a produção de microestrutura e mesmo de aspectos elementares do discurso, 
como as palavras-chave da macroestrutura. Além disso, esses estudos concluem que os afásicos de Broca usam mais substantivos do que verbos, menor número de palavras de classes fechadas do que o esperado e apresentam omissões frequentes de determinantes. É esperado, também, que esses afásicos apresentem sentenças gramaticalmente menos complexas do que os sujeitos normais, que utilizem verbos com as estruturas de argumento mais simples e demonstrem uma gama de omissões de várias estruturas gramaticais (Bird e Franklin, 1996; Goodglass et al. 1993; Armstrong, 2000), como pôde ser observado em nosso estudo.

Por outro lado, os achados de Andreetta et al.(2012) concordam com nosso estudo no que diz respeito à restrição da complexidade textual e dificuldade de acesso lexical no grupo dos afásicos anômicos em comparação aos sujeitos sadios.

Nossa interpretação para a possibilidade de o macroprocessamento basear-se em outros conhecimentos além da micro estrutura concorda com Huber (1990) que admitiu que este macroprocessamento baseado em outros conhecimentos, além da microestrutura, pode estar comprometido nos pacientes afásicos. Embora não haja explicações para os mecanismos subjacentes a essa alteração, é possível formular algumas hipóteses: dificuldades cognitivas, no próprio raciocínio proposicional ou de escolha diante da alta demanda de investimentos concomitantes na micro e macroestrutura. Nesse último caso, haveria vantagens em escolhas no investimento cognitivo em micro ou macroestrutura, a depender da situação. Se aceitarmos a hipótese de que os indivíduos se apoiam em outro tipo de conhecimentos, além da microestrutura para elaborar a macroestrutura, há que 
se levar em conta a possibilidade de que tanto indivíduos sadios quanto afásicos se apoiem no conhecimento partilhado entre examinador e examinado, já que a história da Cinderela é de domínio público.

\subsection{Análise do estudo 2}

O estudo 2 consistiu em analisar a microestrutura e a macroestrutura dos sujeitos do GA1, englobando as narrativas da prancha do Roubo dos Biscoitos e da história da Cinderela em três momentos (até um mês, 3 meses e 6 meses após o AVC) a fim de verificar evolução da linguagem e diferenças intra-grupo de afásicos (afásicos de Broca vs. anômicos).

A seguir, descreveremos a análise do discurso por meio da prancha Roubo dos Biscoitos.

No que diz respeito à comparação dos parâmetros da macroestrutura e da microestrutura nos três momentos, nota-se que no nível de macroestrutura, tanto a variável orientação quanto total de proposições mostraram-se significativamente maiores após 6 meses do AVC, e no parâmetro orientação, diferenças foram observadas também após 3 meses. Isso significa que foi possível verificar melhora do discurso no nível da macroestrutura nos intervalos estudados. Com relação à microestrutura, as medidas iniciais das variáveis sílabas por palavra de conteúdo, incidência de substantivos e incidência de palavras de conteúdo diferiram positivamente após 6 meses. Já a variável incidência de palavras ausentes no dicionário apresentou valor significantemente menor após três meses de AVC. Nota-se redução da quantidade de palavras ausentes no dicionário, justificada pelo fato de que os afásicos ampliaram o repertório lexical e a fluência de produção do discurso. 
Ainda com relação à macroestrutura, não houve diferença entre 0 número de proposições na avaliação após um mês e 3 meses após o AVC. Porém, após 6 meses do AVC, o número de proposições do bloco desfecho mostrou-se significativamente menor do que os produzidos nos blocos problema e desenvolvimento. Houve ainda aumento do número do número de proposições relacionadas ao bloco problema e também no total de proposições.

A comparação dos parâmetros de análise entre afásicos de Broca e anômicos indica diferenças apenas no número de sílabas por palavra de conteúdo e estatística de Honoré, sendo maior nos afásicos anômicos, o que significa que eles constroem textos com maior complexidade do que os afásicos de Broca.

A seguir, descreveremos a análise do discurso produzido sobre a Cinderela.

No que diz respeito à comparação da macro e microestrutura na sequência de avaliações (até 1 mês, 3 e 6 meses após o AVC), podemos afirmar que houve aumento de proposições em todos os blocos com exceção do desfecho. Ocorre que na primeira avaliação os indivíduos já produziram as duas proposições esperadas; houve então efeito teto, que explica a ausência de significância estatística.

No nível da microestrutura, somente a variável índice de leiturabilidade de Flesch e quantidade de palavras apresentaram diferenças após 3 e 6 meses do AVC, o que denota melhora no aumento do vocabulário e da estrutura sintática. Assim sendo, foi possível constatar a evolução dos sujeitos por meio 
das análises em ambos os níveis, o que concorda com Stark (2013) que também realizou estudo longitudinal.

Ao descrever os valores medianos do índice de acertos entre as variáveis do nível macroestrutural até um mês após AVC, nota-se que a orientação difere tanto do desfecho quanto do total de proposições, sendo a orientação significativamente maior que o desfecho e menor que o total de proposições. A comparação entre os valores medianos do índice de acertos entre as variáveis do nível macroestrutural após 3 meses do AVC indicou diferenças significativas (Tabela 13) apenas entre os blocos desenvolvimento e desfecho, sendo o desfecho significativamente maior. Não houve diferença entre número de acertos entre os índices após 6 meses de AVC. Podemos justificar o conjunto de mudanças positivas pela melhora na construção global do discurso (Tabela 16).

Os estudos longitudinais consultados em nossa revisão relacionaram alguns aspectos micro e macroestruturais do discurso e tentaram explicar as mudanças observadas. Esta é uma forma de quantificar as mudanças que são frequentemente evidentes intuitivamente no discurso afásico ao longo do tempo, mas que são difíceis de capturar. Há também dificuldade em classificar as mudanças como melhora ou comprometimento, com base apenas em dados quantitativos, como observado por Prins et al. (1978). Antes de se poder afirmar que certo fenômeno representa um ou outro, é preciso examinar o sucesso na organização global, isto é, nos aspectos macrolinguísticos do texto.

Um grupo de estudos longitudinais que se concentraram mais em coesão e estrutura textual descreveram mudanças, a partir de perspectiva 
qualitativa. Ao examinar a coesão, Piehler e Holland (1984), Coelho et al. (1994) e Armstrong (1997) relataram mudanças positivas na microestrutura do discurso de seus sujeitos ao longo do tempo, apresentando como consequência, evolução em relação a macroestrutura.

Finalmente, no estudo 2, temos a comparação entre os parâmetros de análise micro e macroestruturais segundo o tipo de história, em cada período (início, 3 e 6 meses). Nota-se que no nível macroestrutural diferenças entre as histórias só foram observadas 6 meses após o AVC para o bloco desfecho. Esse resultado mostra a possibilidade de elicitação do discurso tanto por meio de prancha única quanto pela sequência de pranchas para a avaliação da evolução do discurso, no que tange à macroestrutura.

Quanto ao aspecto microestrutural, porém, diferenças significantes entre as histórias em todos os tempos avaliados (inicial, 3 meses e 6 meses) foram observadas para os parâmetros: índice de leiturabilidade de Flesch, quantidade de palavras, relação Tipo por Token e índice de Brunet. Após 3 meses, além dessas variáveis, o parâmetro índice de pronomes pessoais diferiu entre as histórias e, aos 6 meses, o parâmetro incidência de adjetivos também diferiu entre as histórias. Podemos concluir, então, que no nível da macroestrutura, ambas as histórias convergiram em relação aos resultados, porém no nível da microestrutura, houve divergências, sendo a história da Cinderela mais vantajosa para avaliar a complexidade textual e o léxico. Podemos explicar esse resultado pelo fato de a narração de cena única induzir descrição e a narração de cenas, em sequência, induzir narrativa, sendo essa última, portanto, mais adequada para a avaliação em contexto clínico. 
Em relação às proposições da história da Cinderela, podemos dizer que houve proposições que não foram relatadas ou raramente relatadas pelos sujeitos afásicos e tampouco foram mencionadas pelos sujeitos cognitivamente sadios, em ambos os estudos, como: menina rica, Cinderela feliz com o vestido, fada madrinha medindo Cinderela para novo vestido, animais soltam Cinderela. Podemos explicar pelo fato de serem proposições que estão indiretamente presentes em outras proposições ou que são detalhes da história pouco recordados pela população. Dessa forma, podemos pensar em reduzir a quantidade de proposições para a análise da macroestrutura em estudos futuros. Por outro lado, verificamos a existência de proposições que são essenciais na história, como: limpando o sótão/serviçal, fada madrinha aparece, fada madrinha faz da um vestido para Cinderela, meia noite Cinderela perde sapato na escada, Cinderela experimenta sapato e serve, proposições que foram relatadas pela maioria dos sujeitos.

Em relação ao SPECT, como dito anteriormente, o GA1 realizou o SPECT em dois momentos, até um mês após o AVC e 6 meses após o AVC. Notou-se que o SPECT possibilitou a detecção de lesões não constatadas na TC de alguns sujeitos e que não houve modificações nas imagens do SPECT nos dois momentos avaliados. Isto significa que o SPECT não detectou recuperação do metabolismo cerebral nas áreas lesadas nesse intervalo de tempo.

Observamos, portanto, que a análise comportamental da produção do discurso nos três momentos, foi capaz de diferenciar e mostrar mudanças positivas nos sujeitos afásicos e pode ser incluída na avaliação da evolução da afasia (estímulos prancha única ou em sequência). 


\subsection{Limitações do estudo}

A amostra foi constituída por um grupo reduzido de sujeitos afásicos e não houve pareamento de idade e escolaridade entre o grupo controle e 0 grupo de afásicos. Há necessidade de pareamento de características sócio demográficas entre os grupos controle e afásicos, a fim de que se possa analisar a gravidade da afasia nos diferentes momentos de avaliação.

Reconhecemos a importância de replicação do estudo em população maior, de afásicos, tendo em vista que o sistema de análise computacional foi concebido para a aplicação em análises de população sadia do ponto de vista cognitivo e necessita ser "treinado" para o emprego em contexto de população afásica.

Outra limitação diz respeito à ausência de métricas para detectar alterações paralinguísticas que meçam de forma precisa, fenômenos como duração e localização de pausas, ritmo e velocidade de fala, já que as características paralinguísticas também podem estar afetadas nos pacientes afásicos.

E, finalmente, destacamos a ausência de uso de tecnologia computadorizada para análise da macroestrutura do discurso. Dado que a utilização da ferramenta computacional com essa finalidade não foi bem sucedida, houve necessidade de se realizar a análise manualmente. Ressaltamos a necessidade de investigações adicionais para o uso dessa ferramenta com a população de afásicos. 


\section{CONCLUSÕES}

O discurso produzido a partir da história da Cinderela e da prancha Roubo dos Biscoitos gerou material para análise de macroestrutura e microestrutura, possibilitando quantificar e qualificar a evolução da linguagem em diferentes fases da instalação do AVC e distinguir o comportamento de indivíduos sadios, com afasia de Broca e anômicos.

A exploração de ferramentas computadorizadas facilitou a análise dos dados em relação à microestrutura, porém não foi aplicável à macroestrutura, demonstrando que a ferramenta Deep Bond precisa ser aperfeiçoada para a aplicação ao discurso de afásicos.

Os dados do SPECT não refletiram a melhora comportamental da linguagem dos sujeitos afásicos. 


\section{ANEXOS}

ANEXO A - Aprovação CAPPesq

USP - HOSPITAL DAS
CLINICAS DA FACULDADE DE
MEDICINA DA UNIVERSIDADE
PARECER CONSUBSTANCIADO DO CEP

DADOS DO PROJETO DE PESQUISA

Título da Pesquisa: Narrativas produzidas por individuos afásicos e individuos cognitivamente sadios: análise computadorizada de macro e micro estrutura

Pesquisador: Leticia Lessa Mansur

Area Temática:

Versäo: 1

CAAE: 65043617.9 .0000 .0068

Instituiçäo Proponente:HOSPITAL DAS CLINICAS DA FACULDADE DE MEDICINA DA U S P

Patrocinador Principal: Financiamento Próprio

DADOS DO PARECER

Número do Parecer: 1.855 .848

Apresentação do Projeto:

Este é um protocolo voltado para pacientes afásicos.

Objetivo da Pesquisa:

Visa avaliar sua capacidade de comunicação através de metodizaçăo especifica, com análise computadorizada das respostas.

Avaliaçäo dos Riscos e Beneficios:

Os riscos săo negligenciáveis, e haverá coleta de informaçöes potencialmente úteis para o manejo desta populaçäo.

Comentários e Consideraçöes sobre a Pesquisa:

0 protocolo se encontra corretamente escrito e delineado. Trata-se de tema relevante e atual.

Consideraçöes sobre os Termos de apresentação obrigatória:

Os TCLEs sẫo adequados.

Recomendaçōes:

Năo há.

Conclusōes ou Pendências e Lista de Inadequações:

Năo há pendèncias.

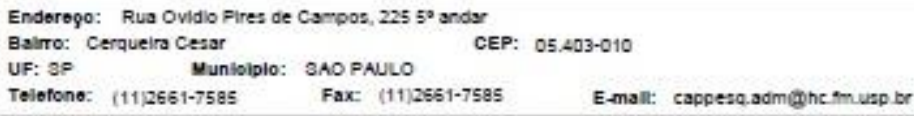




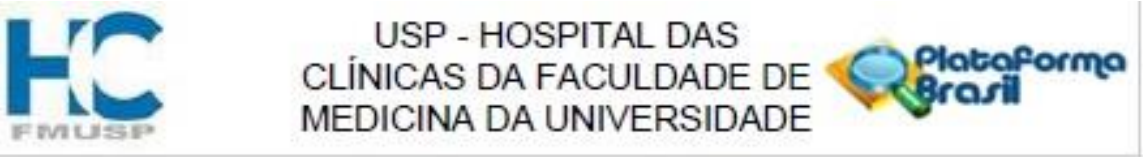

Sortinuagho de Parecer. 1.955 ste

Zonsideraçöes Finais a critério do CEP:

Em conformidade com a Resoluçäo CNS $n^{\circ} 466 / 12$ - cabe ao pesquisador: a) desenvolver o projeto sonforme delineado; b) elaborar e apresentar relatórios parciais e final; c)apresentar dados solicitados pelo JEP, a qualquer momento; d) manter em arquivo sob sua guarda, por 5 anos da pesquisa, contendo fichas ndividuais e todos os demais documentos recomendados pelo CEP; e) encaminhar os resultados para sublicação, com os devidos créditos aos pesquisadores associados e ao pessoal técnico participante do rojeto; f) justificar perante ao CEP interrupçăo do projeto ou a năo publicaçăo dos resultados.

Este parecer foi elaborado baseado nos documentos abaixo relacionados:

\begin{tabular}{|c|c|c|c|c|}
\hline Tipo Documento & Arquivo & Postagem & Autor & Situação \\
\hline $\begin{array}{l}\text { Informações Básicas } \\
\text { do Projeto }\end{array}$ & $\begin{array}{l}\text { PB_INFORMAC_EES_BASICAS_DO_P } \\
\text { ROJETO } 815038 \text { pdf }\end{array}$ & $\begin{array}{c}21 / 02 / 2017 \\
18: 43-55\end{array}$ & & Aceito \\
\hline Folha de Rosto & Folha_de_rosto_PB.pdf & $\begin{array}{c}21 / 02 / 2017 \\
18: 40: 17\end{array}$ & Leticia Lessa Mansur & Aceito \\
\hline Outros & TCLE_controles.pdf & $\begin{array}{c}18 / 02 / 2017 \\
08: 07-51\end{array}$ & Leticia Lessa Mansur & Aceito \\
\hline $\begin{array}{l}\text { TCLE / Termos de } \\
\text { Assentimento / } \\
\text { Justificativa de } \\
\text { Auséncia }\end{array}$ & TCLE_afasicos.pdf & $\begin{array}{c}16 / 02 / 2017 \\
08: 07: 21\end{array}$ & Leticia Lessa Mansur & Aceito \\
\hline $\begin{array}{l}\text { Projeto Detalhado / } \\
\text { Brochura } \\
\text { Investioador }\end{array}$ & PP_Gabriela_Silveira.pdf & $\begin{array}{c}16 / 02 / 2017 \\
08: 06-27\end{array}$ & Leticia Lessa Mansur & Aceito \\
\hline Outros & Anexo_II.pdf & $\begin{array}{c}01 / 12 / 2016 \\
12: 26: 17\end{array}$ & Leticia Lessa Mansur & Aceito \\
\hline
\end{tabular}

Situação do Parecer:

Aprovado

Necessita Apreciaçăo da CONEP:

Não

SAO PAULO, 09 de Março de 2017

Assinado por:
Joel Faintuch
(Coordenador)

Endereqo: Rua Ovidio Fires de Campos, $2255^{\circ}$ andar

Baire: Cerqueira Cesar $\quad$ CEP: 05.403-010

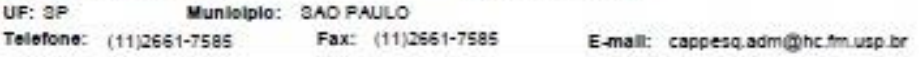


ANEXO B - Termos de Consentimento Livre e Esclarecido

hOSPITAL DAS CLÍNICAS DA FACULDADE DE MEDICINA DA UNIVERSIDADE DE SÃO PAULO-HCFMUSP

TERMO DE CONSENTIMENTO LIVRE E ESCLARECIDO

\section{DADOS DE IDENTIFICAÇÃO DO SUJEITO DA PESQUISA OU RESPONSÁVEL LEGAL}

1. NOME:

DOCUMENTO DE IDENTIDADE N:

SEXO: $M \square F \square$

DATA DE NASCIMENTO:

ENDEREÇO:

$\mathrm{N}^{\circ}$

APTO

BAIRRO:

CIDADE:

CEP:

TELEFONE:

2. RESPONSÁVEL LEGAL:

NATUREZA (grau de parentesco, tutor, curador, etc.):

DOCUMENTO DE IDENTIDADE N: SEXO: $M \square F \square$

DATA DE NASCIMENTO:

ENDEREÇO:.

$\mathrm{N}^{\circ}$ APTO

BAIRRO:

CIDADE:

CEP: .TELEFONE: (.....).

\section{DADOS SOBRE A PESQUISA}

1. TÍTULO DO PROTOCOLO DE PESQUISA: Narrativas produzidas por indivíduos afásicos e indivíduos cognitivamente sadios: análise computadorizada de macro e micro estrutura

2. PESQUISADOR: Leticia Lessa Mansur

CARGO/FUNÇÃO: Professora associada INSCRIÇÃO CONSELHO REGIONAL nº 0856

UNIDADE DO HCFMUSP: Faculdade de Medicina- USP -Departamento de Fisioterapia, Fonoaudiologia e Terapia Ocupacional.

3. AVALIAÇÃO DO RISCO DA PESQUISA:

$\begin{array}{lrr}\text { RISCO MÍNIMO } & X & \text { RISCO MÉDIO } \square \\ \text { RISCO BAIXO } \square & & \text { RISCO MAIOR } \square\end{array}$




\section{DURAÇÃO DA PESQUISA : 1 ano}

\section{hOSPITAL DAS CLÍNICAS DA FACULDADE DE MEDICINA DA UNIVERSIDADE DE SÃO PAULO-HCFMUSP}

O senhor(a) está sendo convidado(a) a participar voluntariamente neste estudo Narrativas produzidas por indivíduos afásicos e indivíduos cognitivamente sadios: análise computadorizada de macro e micro estrutura que tem por objetivo avaliar a linguagem de pacientes que sofreram derrame (acidente vascular cerebral), por meio de narrativa de uma história que ouvia quando criança. O senhor(a) observará cenas de livro e, depois, contará a história com suas palavras. Tais dados auxiliarão a entender como pessoas sadias constroem uma história e a partir daí entender o que ocorre com pessoas que tiveram acidente vascular cerebral (derrame). Não é esperado benefício direto e imediato a você ou seu familiar/paciente. Espera-se no final do estudo contribuir para os conhecimentos sobre a linguagem e a partir daí aprimorar orientações e planejamentos para 0 atendimento fonoaudiológico. $O$ estudo de narrativas em geral é realizado com esses procedimentos. Em qualquer etapa do estudo, você terá acesso aos profissionais responsáveis pela pesquisa para esclarecimentos de dúvidas. $O$ principal investigador é a Prof Leticia Lessa Mansur que pode ser encontrada no endereço Rua Cipotanea n. 51 Telefone(s) 11-3091-8414. Se você tiver alguma consideração ou dúvida sobre a ética da pesquisa, entre em contato com o Comitê de Ética em Pesquisa (CEP) - R. Ovídio Pires de Campos, 225 - 5o andar - tel: 3069-6442 ramais 16, 17, 18, 20. E-mail: cappesa@hcnet.usp.br. É garantida a liberdade da retirada de consentimento a qualquer momento e deixar de participar do estudo, sem qualquer prejuízo à continuidade de seu tratamento no Hospital das Clínicas. As informações obtidas serão analisadas em conjunto com outros pacientes, não sendo divulgada a identificação de nenhum participante. É garantido o seu direito de ser mantido atualizado sobre os resultados parciais que sejam do conhecimento dos pesquisadores. Não há despesas pessoais para o participante em qualquer fase do estudo, incluindo exames e consultas. Também não há compensação financeira relacionada à sua participação. Se existir qualquer despesa adicional, ela será absorvida pelo orçamento da pesquisa. O pesquisador assume o compromisso de utilizar os dados e o material coletado somente para esta pesquisa.

\section{HOSPITAL DAS CLÍNICAS DA FACULDADE DE MEDICINA DA UNIVERSIDADE DE SÃO PAULO-HCFMUSP}

Acredito ter sido suficientemente informado a respeito do estudo "Narrativas produzidas por indivíduos afásicos e indivíduos cognitivamente sadios: análise computadorizada de macro e micro estrutura".

Eu discuti com a Dra Leticia Lessa Mansur e com Gabriela Silveira, que é pesquisadora executante, sobre a minha decisão em participar nesse estudo. Ficaram claros para mim quais são os objetivos do estudo, os procedimentos a serem realizados, seus desconfortos e riscos, as garantias de confidencialidade e de esclarecimentos permanentes. Ficou claro também que não terei despesas com minha participação e que tenho garantia do acesso a tratamento hospitalar quando necessário. Concordo voluntariamente em participar deste estudo e poderei retirar o meu consentimento a qualquer momento, antes ou durante o mesmo, sem penalidades ou prejuízo ou perda de qualquer benefício que eu possa ter adquirido, ou no meu atendimento neste Serviço.

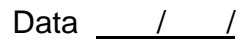


(Somente para o responsável do projeto)

Declaro que obtive de forma apropriada e voluntária o Consentimento Livre e Esclarecido deste paciente ou representante legal para a participação neste estudo.

HOSPITAL DAS CLÍNICAS DA FACULDADE DE MEDICINA DA UNIVERSIDADE DE SÃO PAULO-HCFMUSP

TERMO DE CONSENTIMENTO LIVRE E ESCLARECIDO

\section{DADOS DE IDENTIFICAÇÃO DO SUJEITO DA PESQUISA OU RESPONSÁVEL LEGAL}

3. NOMEDOCUMENTO DE IDENTIDADE $\mathrm{N}^{\circ}$ :

SEXO: $M \square F \square$

DATA DE NASCIMENTO:....................

ENDEREÇO:

$\mathrm{N}^{\circ}$.

APTO.

BAIRRO:

CIDADE:

CEP:

TELEFONE: (.....).

4. RESPONSÁVEL LEGAL:

NATUREZA (grau de parentesco, tutor, curador, etc.):

DOCUMENTO DE IDENTIDADE N ${ }^{\circ}$ :

SEXO: $M \square F \square$

DATA DE NASCIMENTO:

$\mathrm{N}^{\circ}$

APTO

ENDEREÇO:

CIDADE:

BAIRRO:

TELEFONE:

CEP:

$(. . .$.

\section{DADOS SOBRE A PESQUISA}

5. TÍTULO DO PROTOCOLO DE PESQUISA: Narrativas produzidas por indivíduos afásicos e indivíduos cognitivamente sadios: análise computadorizada de macro e micro estrutura

6. PESQUISADOR: Leticia Lessa Mansur

CARGO/FUNÇÃO: Professora associada INSCRIÇÃO CONSELHO REGIONAL n 0856

UNIDADE DO HCFMUSP: Faculdade de Medicina da USP - Departamento de Fisioterapia, Fonoaudiologia e Terapia Ocupacional. 
7. AVALIAÇÃO DO RISCO DA PESQUISA:

$\begin{array}{llr}\text { RISCO MÍNIMO } & X & \text { RISCO MÉDIO } \square \\ \text { RISCO BAIXO } & & \text { RISCO MAIOR } \square\end{array}$

8. DURAÇÃO DA PESQUISA : 1 ano 


\section{HOSPITAL DAS CLÍNICAS DA FACULDADE DE MEDICINA DA UNIVERSIDADE DE SÃO PAULO-HCFMUSP}

O senhor(a) está sendo convidado(a) a participar voluntariamente neste estudo intitulado Narrativas produzidas por indivíduos afásicos e indivíduos cognitivamente sadios: análise computadorizada de macro e micro estrutura que tem por objetivo avaliar a linguagem de pacientes que sofreram derrame (acidente vascular cerebral), por meio de narrativa de uma história que ouvia quando criança. O senhor(a) observará cenas de um livro e, depois, contará a história com suas palavras. Antes da avaliação de linguagem, o senhor(a) responderá a perguntas sobre sua saúde e realizará exames neurológico e radiológico para verificar como seu cérebro funciona depois do AVC. No exame neurológico, o senhor será solicitado a realizar movimentos de membros e de olhos e também responderá perguntas. $O$ exame radiológico chamado SPECT consiste em injeção na veia de um produto que se concentra dentro das células do sistema nervoso e mostra como o cérebro está funcionando (metabolismo cerebral). Os riscos são mínimos, relacionados apenas a probabilidade de reação adversa a medicamentos (incluindo reação alérgica). Não existe dano ou risco para o paciente nas doses de radiação habitualmente utilizadas nos procedimentos diagnósticos de medicina nuclear. A contra - indicação é a realização em gestantes e mulheres em amamentação. Tais dados auxiliarão a direcionar de maneira mais eficaz a reabilitação e a explicar os resultados obtidos. Não é esperado benefício direto e imediato a você ou seu familiar/paciente. Espera-se no final do estudo contribuir para os conhecimentos sobre a linguagem e a partir daí aprimorar orientações e planejamentos para o atendimento fonoaudiológico. Entre os procedimentos que permitem entender a reorganização cerebral, o SPECT é o mais simples do ponto de vista da realização. Você terá acesso aos profissionais responsáveis pela pesquisa para esclarecimentos de dúvidas. O principal investigador é a Profa Leticia Lessa Mansur que pode ser encontrada no endereço Rua Cipotanea n. 51 Telefone(s) 11-3091-8414. Se você tiver alguma consideração ou dúvida sobre a ética da pesquisa, entre em contato com o Comitê de Ética em Pesquisa (CEP) - R. Ovídio Pires de Campos, 225 - 5o andar - tel: 3069-6442 ramais 16, 17, 18, 20. E-mail: cappesq@hcnet.usp.br. É garantida a liberdade da retirada de consentimento a qualquer momento e você pode deixar de participar do estudo, sem qualquer prejuízo à continuidade de seu tratamento no ambulatório Fonoaudiologia. As informações obtidas serão analisadas em conjunto, não sendo divulgada a identificação de nenhum participante. É garantido o seu direito de ser mantido atualizado sobre os resultados parciais que sejam do conhecimento dos pesquisadores. Não há despesas pessoais para o participante em qualquer fase do estudo, incluindo exames e consultas. Também não há compensação financeira relacionada à sua participação. Se existir qualquer despesa adicional, ela será absorvida pelo orçamento da pesquisa. $O$ pesquisador assume o compromisso de utilizar os dados e o material coletado somente para esta pesquisa.

\section{hOSPITAL DAS CLÍNICAS DA FACULDADE DE MEDICINA DA UNIVERSIDADE DE SÃO PAULO-HCFMUSP}

Acredito ter sido suficientemente informado a respeito do estudo "Narrativas produzidas por indivíduos afásicos e indivíduos cognitivamente sadios: análise computadorizada de macro e micro estrutura".

Eu discuti com a Dra Leticia Lessa Mansur e com Gabriela Silveira, que é a pesquisadora executante, sobre a minha decisão em participar nesse estudo. Ficaram claros para mim quais são os propósitos do estudo, os procedimentos a serem realizados, seus desconfortos e riscos, as garantias de que meus dados só serão divulgados sem identificação. Alem disso ficou claro meu direito de ser esclarecido sempre que julgar necessário. Ficou claro também que minha participação é isenta de despesas e que tenho garantia do acesso a tratamento hospitalar quando necessário. Concordo voluntariamente em participar deste estudo e poderei retirar 0 meu consentimento a qualquer momento, antes ou durante o mesmo, sem penalidades ou prejuízo ou perda de qualquer benefício que eu possa ter adquirido, ou no meu atendimento neste Serviço. 
Assinatura da testemunha

Data

para casos de pacientes menores de 18 anos, analfabetos, semi-analfabetos ou portadores de deficiência auditiva ou visual.

(Somente para o responsável do projeto)

Declaro que obtive de forma apropriada e voluntária o Consentimento Livre e Esclarecido deste paciente ou representante legal para a participação neste estudo.

Assinatura do responsável pelo estudo

Data 


\section{ANEXO C - Mini Exame do Estado Mental (MEEM) \\ Mini-Exame do Estado Mental - MEEM (Folstein et al., 1975)}

Orientação temporal - Pergunte ao indivíduo (dê um ponto para cada resposta correta)

- Em que dia estamos?

- Em que mês estamos?

- Em que ano estamos?

- Em que dia da semana estamos?

- Qual a hora aproximada (considere a variação de mais ou menos uma hora)

Orientação espacial - Pergunte ao indivíduo (dê um ponto para cada resposta correta)

- Em que local nós estamos? (consultório, dormitório, sala - apontando para o chão)

- Que local é este aqui? (apontando ao redor num sentido mais amplo: hospital, casa de repouso, própria casa).

- Em que bairro nós estamos ou qual o nome de uma rua próxima?

- Em que cidade nós estamos?

- Em que estado nós estamos?

\section{Memória imediata}

- Eu vou dizer 3 palavras e você irá repeti-las a seguir: carro, vaso, tijolo (dê 1 ponto para cada palavra repetida acertadamente na $1^{\mathrm{a}}$ vez, embora possa repeti-las até 3 vezes para o aprendizado, se houver erros)

\section{Atenção e cálculo}

- Subtração de setes seriadamente (100-7; 93-7; 86-7; 79-7; 72-7; 65). Considere 1 ponto para cada resultado correto. Se houver erro, corrija-o e prossiga. Considere correto se o examinado espontaneamente se autocorrigir.

\section{Evocação das palavras}

Pergunte quais as palavras que o sujeito acabara de repetir - 1 ponto para cada.

Linguagem
Nomeação: Peça para o sujeito nomear os objetos mostrados (relógio, caneta) - 1
ponto para cada.

Repetição: Preste atenção: vou lhe dizer uma frase e quero que você repita depois de mim: "Nem aqui, nem ali, nem lá". Considere somente se a repetição for perfeita (1 ponto)
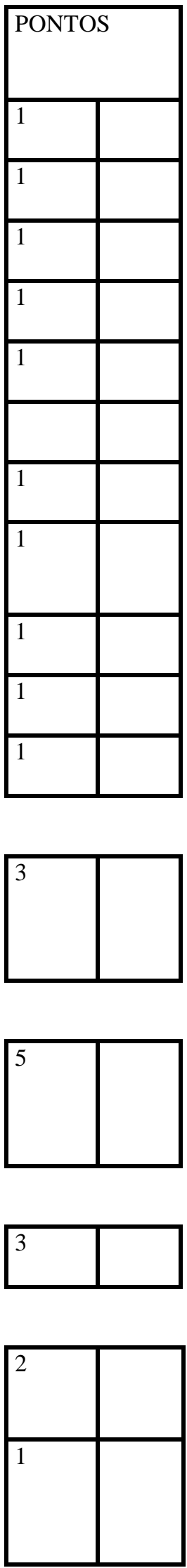
Comando: "Pegue este papel com sua mão direita (1 ponto), dobre ao meio (1 ponto) e coloque no chão (1 ponto)". Total de 3 pontos. Se o sujeito pedir ajuda no meio da tarefa não dê dicas.

Leitura: mostre a frase escrita "FECHE OS OLHOS" e peça para o indivíduo fazer o que está sendo mandado. Não auxilie se pedir ajuda ou se só ler a frase sem realizar o comando.

Escrita: Peça ao indivíduo para escrever uma frase. Se não compreender o significado, ajude com: alguma frase que tenha começo, meio e fim; alguma coisa que aconteceu hoje; alguma coisa que queira dizer. Para a correção não são considerados erros gramaticais ou ortográficos (1 ponto).

Copia do desenho: Mostre o modelo e peça para fazer o melhor possível. Considere apenas se houver 2 pentágonos interseccionados formando uma figura de quatro lados (1 ponto)

\begin{tabular}{|l|l|}
\hline 3 & \\
\hline 1 & \\
& \\
\hline 1 & \\
& \\
\hline 1 & \\
& \\
\hline
\end{tabular}


ANEXO D - Tarefas de fluência verbal

A fluência verbal é sub-dividida em provas semânticas (FS): animais e fonêmicas (FF):

F, A, S. Instruções: Diga: “Eu quero que você diga, em 1 minuto, o máximo possível de nomes diferentes de (animais, ou coisas que começam com a letra F/A/S). Você está pronto? Então pode começar!’. Inicie a contagem do tempo. 


\section{ANEXO E - Critério de MOANS}

\section{MAYO OLDER AMERICAN NORMATIVE STUDIES: MOANS}

\section{Critérios para classificação como normal para indivíduos de 55 anos ou mais}

1. Ausência de doença psiquiátrica ou neurológica em atividade

2. Ausência de queixa de dificuldade cognitiva durante a anamnese e interrogatório sobre os diferentes aparelhos, e ausência, ao exame físico, de achado sugestivo de transtornos com potencial para afetar a cognição.

3. Ausência de uso de medicação psicotrópica em quantidades que possam comprometer a cognição ou sugerir transtorno neuropsiquiátrico.

4. Status de vida independente na comunidade.

5. Histórias pregressas de transtornos (p.ex: alcoolismo) com potencial para afetar a cognição não são excluídos automaticamente desde que os transtornos não estejam em atividade e tenha havido recuperação sem seqüela cognitiva aparente.

6. Doenças médicas crônicas não são excluíveis desde que a condição não seja relatada pelo médico como responsável por comprometimento da cognição.

Fonte

Smith GE, Ivnik RJ. Normative neuropsychology. In: Petersen RC: Mild Cognitive Impairment, New York: Oxford, 2003: 63-88. 


\title{
ANEXO F - Exemplos de transcrições de discurso de afásicos de acordo com a
}

\author{
escala de gravidade da afasia.
}

\begin{tabular}{|l|l|}
\hline Pontuação & Descrição \\
\hline 0 ( ) & Não utiliza fala funcional ou compreensão auditiva. \\
\hline 1 ( ) & $\begin{array}{l}\text { Toda a comunicação é através de expressão fragmentada; grande necessidade de } \\
\text { inferência, questionamento ou adivinhação por parte do interlocutor. A informação } \\
\text { possível de ser intercambiada é limitada e o ouvinte assume a responsabilidade pela } \\
\text { comunicação. }\end{array}$ \\
\hline 2 ( ) & $\begin{array}{l}\text { A conversação sobre temas familiares é possível com ajuda do interlocutor. Ocorrem } \\
\text { freqüentes falhas para veicular a idéia, mas o paciente é capaz de compartilhar a } \\
\text { responsabilidade pela comunicação. }\end{array}$ \\
\hline 3 ( ) & $\begin{array}{l}\text { O paciente pode discutir quase todos os problemas da vida cotidiana com pouca ou } \\
\text { nenhuma assistência. A redução da fala e/ou compreensão, entretanto, torna a } \\
\text { conversação sobre determinados temas impossível. }\end{array}$ \\
\hline 5 ( ) & $\begin{array}{l}\text { Ocorre perda óbvia da fluência na fala ou há alguma dificuldade para compreensão, sem } \\
\text { limitação significante nas idéias expressas ou forma de expressão. }\end{array}$ \\
\hline óbvias para o ouvinte.
\end{tabular}

Pontuação 2: "aqui aqui parece uma paz mão mão e pa se pa e esse num tá sabendo / este homem este esse paz / este menina e este va esse aqui e nos eu sevo no vaca não é vaca né e to / e esta menina e ma / mãe e pai // pausa 12 segundos // os nesse // pausa 17 segundos // esta menina vem aqui e eu sei da ficando não // pausa 17 segundos // este esta e esta menina e aqui e essa (ininteligivel) / é isso // pausa 20 segundos // neste menina aqui pegando né / hum // pausa 7 segundos // menina aqui ta la e aqui // pausa 28 segundos // aqui e menina aqui // pausa 8 segundos // aqui va va esta aqui vestido né e aqui é e este // pausa 26 segundos // esta aqui ta falando aqui né isso aqui é // pausa 20 segundos // aqui no aqui arvore também e aqui ta / aqui abeza // pausa 17 segundos // aqui menina ta com esta ela ta falando falando // pausa 14 segundos // aqui e essa e essa aqui falando // pausa 20 segundos // isso aqui assim falando né e aqui // pausa 18 segundos // ta falando falando num este falando // pausa 10 segundos // aqui ta falando aqui / não sei // pausa 6 segundos // hum aqui ta falando aqui e aqui ta falando // pausa 15 segundos // este é homem tá falando / este tá falando falando né / este falando falando este aqui não sei / não sei / sim parece que parece homem / perna aqui e perna perna este não serve // pausa 13 segundos // este e esta e ta aqui falan oito e aqui vi e não sabe".

Pontuação 3: "cinderela tava comendo comendo desculpa não cinderela ta dando comida pro cavalo e estava junto com com um homem / estava junto tomando conta enquanto ela estava dando pro cava pro cacho pro caho pro cavalo pra ele comer / ela juntou eh passeou bastante com o cavalo e perde do castelo onde ela morava e ela gostava muito do cavalo / hum então a cin a cinderela ela tinha tres bruxas más que não gostavam dela mas ela tava tava abusando um pouquinho do de como ela era bonita de como ela era bonita e ela ela elas eram feias / mesmo assim ela a cinderela 
tinha que tomar conta do das dos das coisas do do ca do cavalo de onde ela morava e abusava e tomar conta de tomar conta de das coisas que ela que ela ela // pausa 5 segundos // tomava conta do castelo onde ela morava / a bruxa as tias más faziam coisas com ela e brigavam com ela e deixavam ela muito tristes / ela um dia ela foi no no portão e percebeu que tinha um cara pra entregar cartas pra ela / mas enquanto a bruxa brigava com ela fala falando falando que ela era era era era mais bonita do que elas / aconteceu então uma festa os ratinhos começaram a do come do come cozinha fazer coisas e não quiseram mexer nas coisas de costura e acho que é isso / e eles resolveram fazer uma roupa pra ela pra ela ir pro pra festa junto com o casamento / não é casamento mas / as tias então na verdade ah eram duas irmãs tudo bem eh as duas irmãs brigaram com ela e tiraram tiraram a roupa as coisas que fizeram pra ela / ela ficou triste / então a tia ela encontrou uma fa uma fada que vai ajudar ela a fazer as coisas e ela fez de novo a roupas delas // pausa 5 segundos // ela ajudou que ela precisou / posso atender rapidinho // pausa para atender o celular // aí a moça tava fazendo uma umas coisas de de novo pra ela fazer festa pra ela e fazendo roupa da cinderela / a cinderela ta fazendo uma uma cenoura uma cebola é uma é uma uma abobora fazendo abobora grande pra ela se preparar pra festa / a ela foi pra festa e junto com a abobora // pausa 3 segundos // ela então encontrou o namo o principe do castelo e ela pediu se apresentou pra ele / então no meio da festa ela foi embora pra casa e teve um sapatinho que caiu no no meio do do no meio da festa ela precisava ir embora porque era meia noite / ela o cara pegou o sapatinho e ficou ficando de olho nela / e então a moça foi foi vendo ela em casa e prendeu a mulher porque ficou presa em casa / então encontrou que encontrou ele tentou o sapato nas nas nas filhas e não deu certo / então o mestre tentou encontrou a ela que tava no quarto e tentou tentar ajudar ela na na na nossa mocinha na na na sapato sapato tentar por o sapato nela / serviu / eh de repente a de repente a moça então se casou com / a cinderela se casou com o principe no castelo / e viveram felizes para sempre”.

Pontuação 4: "não lembro o nome dela / ela ela ta ela gosta do passarinho eh // pausa 12 segundos // gente eu não lembro o nome da menininha / eh eu não lembro / ela é uma mocinha de ta ta com com o cachorrinho e aqui é um eh eh não gente que coisa horrivel gente / eh aqui era a cor aqui / não sei so fala so sei que ele é um cachorro / ela ela não consigo quem é ela / essa aqui eh ele ta com carinha de feliz e tem tres ga tres coleguinhas dele mas aqui / eh e ja vi tanto essas coisas das crianças gente porque que eu não lembro disso // pausa 10 segundos // eh são tres menininhas e eles eles eles eh eles devem cuidar gatinha não é gatinha / não lembro / coitada gente porque que ela I ela tá ela limpa acho que que os irmãos os tres fizeram ela de não eram agora ela é pobre e ela limpa tudo aqui é pra ela lavar com isso aqui / e aqui são eles eles não eles eh / ela triste ela tem ela ta triste e ele fica fica eles são ela é empregada das amigas que não é mais amigas dela / elas são irmãs eu acho / e ela tá tristinha / isso aqui tinha nome gente ele tinha nome que eles eram ruins e ela era boazinha mas eu não consigo lembrar nada disso / esse aqui / meu Deus / é um rato eh / aqui são são / gente eu vou ter que trocar outro oculos horrivel / e ele funcionava bonitinho antigamente / aqui é um gatinho / que que isso aqui / não consegui enxergar / aqui é um gatinho e aqui tem um dois tres quatro ratinhos / são quatro ratinhos / mas que que eles fazem esse danado / um dois tres quatro / eu não sei / é um matinho ele é um ele / um dois tres quatro / são quatro mais um um gordinho ali / aqui ela ela é uma ela tá triste trista trista // pausa 9 segundos // ele ta dançando cantando alguma coisa // pausa 8 segundos // não sei o que que é isso aqui // pausa 10 segundos // gente olha isso aqui eu lembora dessas coisas mas não consigo lembrar o nome / eh tem uma menininha que tadinha lá quebraram o pulsoro aqui em cima e rasgaram o o o a roupa delas / são dois maus / como era o 
nome dela gente que não consigo lembrar / como que era o nome dela gente / ela ta chorando ta sozinha ta sozinha lá no ela ta num tipo ela dei ta deitada chorando chorando / aqui ela dormo / gente como é que eu não lembro nada do nominho dele / que tristeza / eh aqui eles pediram pediram pra ela fazer uma uma fes uma roupa nova e esse ta ajudando ta fazendo uma rouda uma rouda uma rouda / aqui eles estão fazendo vão fazer a aqui tem um ah // pausa 16 segundos // ta fazendo muda ah meu Deus como que é o nome // pausa 3 segundos // tem tres crianças tres ratos pra ajudar eles com a senhorinha pra como que é o nome disso gente pra ela ir embora isso aqui eles mudam eles mudam / eu não lembro // pausa 6 segundos // ela é ela ela vai ficar com com com dinheiro com coisa de so com as soias com as soia e as crianças ajudando eles pra eles ai não consigo // pausa 4 segundos // a a rua é rua a rua e ela ganhou ela virou uma uma duma sa de uma bonita / ela ficou ela ficou rica / um pedaço / aqui é o paquerinha dela / ela ta gostando dele não lembro nenhum deles de nome deles / como que era o nome / a a ela ta indo embora / ah ela esqueceu a cin como que é ela esqueceu a cinta não é isso não é cinta é ela vai embora ela tem que ir embora pra ela voltar se ela não vem vem se não ela vem po vol toda pobre / ele ta atras dela / ele ta com o o com o ele ta levando a o pé dela que ela foi embora / aqui é uma mãe acho que é madrasta madrasta madrasta ela querando ta que ta quere ta que ta levando se embora / ela ta levando embora / ela essa aqui ela quer namorar com o prin prin prin prin ele ele ta atras daquela menina bonita / não é ela / ela é a mentirosa / aqui o cu o cunhada no pezinho dela que aqui ela tava com o namo com o primo primo e agora ela serviu no no no pezinho dela bem certinho / aqui eles ela vai virar namoradinha dela o amor dela / eles estão indo pra casa dela dele".

Pontuação 5: "a Cinderela era uma não ela com uma madrasta e duas filhas /.../ e ela ela cozinhava muito sabe fazia eh como se fosse um eh /.../ eh como é que fala /.../ ela cozinhava /.../ aí ainda no dia ah veio pra ela a madrasta e ela a Cinderela tava com um muita eh esfarrapada assim sabe /.../ e a madrasta deu um vestido pra ela /.../ eh e um carro assim bonito /.../ aí eh elas iam pro palácio /.../ aí ãh ela se encantou né com com com príncipe aí elas dançaram né /.../ e aí elas dançaram dançaram dançaram e a meia-noite ela desceu as escadas assim e perdeu o sapatinho de cristal /.../ aí eh no dia seguinte eh tinha um um cara que com um sapatinho de cristal /.../ elas colocaram no no pezinho dela né /.../ eh pra ver se servia né /.../ aí aí eh primeiro pra pra primeira irmã que não serviu a segunda e a terceira que era a Cinderela aí serviu /.../ e aí o a Cinderela e o príncipe ficaram assim felizes". 


\section{ANEXO G - Escala de inteligibilidade}

\begin{tabular}{|c|c|c|}
\hline \multicolumn{3}{|c|}{ ESCALA DE INTELIGIBILIDADE - Duffy (1995) } \\
\hline Pontos & Dimensão & Inteligibilidade \\
\hline 10 & $\begin{array}{l}\text { Ambiente } \\
\text { Conteúdo } \\
\text { Eficiência }\end{array}$ & $\begin{array}{l}\text { Normal em todos os ambientes } \\
\text { sem restrições de conteúdo } \\
\text { sem necessidade de reformulações }\end{array}$ \\
\hline 9 & $\begin{array}{l}\text { Ambiente } \\
\text { Conteúdo } \\
\text { Eficiência }\end{array}$ & $\begin{array}{l}\text { Algumas vezes reduzida em situações adversas } \\
\text { quando o conteúdo não está restrito } \\
\text { mas adequada com reformulações }\end{array}$ \\
\hline 8 & $\begin{array}{l}\text { Ambiente } \\
\text { Conteúdo } \\
\text { Eficiência }\end{array}$ & $\begin{array}{l}\text { Algumas vezes reduzida em condições ideais } \\
\text { quando o conteúdo não está restrito } \\
\text { mas adequada com reformulações }\end{array}$ \\
\hline 7 & $\begin{array}{l}\text { Ambiente } \\
\text { Conteúdo } \\
\text { Eficiência }\end{array}$ & $\begin{array}{l}\text { Algumas vezes reduzida em situações adversas } \\
\text { mesmo quando o conteúdo é restrito } \\
\text { mas adequada com reformulações }\end{array}$ \\
\hline 6 & $\begin{array}{l}\text { Ambiente } \\
\text { Conteúdo } \\
\text { Eficiência }\end{array}$ & $\begin{array}{l}\text { Algumas vezes reduzida em situações ideais } \\
\text { quando o conteúdo não está restrito } \\
\text { mesmo quando ensaia reformulações }\end{array}$ \\
\hline 5 & $\begin{array}{l}\text { Ambiente } \\
\text { Conteúdo } \\
\text { Eficiência }\end{array}$ & $\begin{array}{l}\text { Geralmente reduzida em condições adversas } \\
\text { quando o conteúdo não está restrito } \\
\text { mesmo quando ensaia reformulações }\end{array}$ \\
\hline 4 & $\begin{array}{l}\text { Ambiente } \\
\text { Conteúdo } \\
\text { Eficiência }\end{array}$ & $\begin{array}{l}\text { Geralmente reduzida em condições ideais } \\
\text { mesmo quando o conteúdo não está restrito } \\
\text { mas adequada com reformulações }\end{array}$ \\
\hline 3 & $\begin{array}{l}\text { Ambiente } \\
\text { Conteúdo } \\
\text { Eficiência }\end{array}$ & $\begin{array}{l}\text { Geralmente reduzida em condições adversas } \\
\text { mesmo quando o conteúdo está restrito } \\
\text { mesmo quando ensaia reformulações }\end{array}$ \\
\hline 2 & $\begin{array}{l}\text { Ambiente } \\
\text { Conteúdo } \\
\text { Eficiência }\end{array}$ & $\begin{array}{l}\text { Geralmente reduzida em condições ideais } \\
\text { mesmo quando o conteúdo está restrito } \\
\text { mesmo quando ensaia reformulações }\end{array}$ \\
\hline 1 & & $\begin{array}{l}\text { A fala não é viável em qualquer condição, } \\
\text { mesmo facilitada }\end{array}$ \\
\hline
\end{tabular}




\section{ANEXO H - Teste de Boston para o Diagnóstico de Afasia}

I. Conversação e fala espontânea:

A. Respostas sociais simples

B. Conversação livre

C. Descrição de prancha: "Roubo dos Biscoitos".

II. Compreensão auditiva:

A. Compreensão de palavras:

1. Discriminação básica de palavras / 2.Ordens: o sujeito tem que realizar ordens.

B. Material Ideacional Complexo

C. Expressão oral:

A. Sequências automatizadas / B. Repetição: palavras isoladas e sentenças

B. Denominação: 1.Denominação responsiva / 2. Nomeação - Boston / 3. Varredura para categorias específicas

III. Leitura:

A. Reconhecimento de símbolos básicos:

1. Emparelhar letras e palavras

2. Emparelhamento de números: a) Dedos- números arábicos / b) Números arábicosdados

B. Identificação de palavras - emparelhamento palavra-figura

C. Leitura oral:

1. Leitura oral de palavras - nível básico

D. Leitura oral de sentenças com compreensão

E. Compreensão de leitura: parágrafos e sentenças

IV. Escrita:

A. Mecânica da escrita

B. Habilidade básica de codificação:

Ditado de palavras :1. simples / 2. regulares/3. irregulares frequentes

C. Denominação escrita (figuras)

D. Narrativa escrita:

1. Narração escrita 
ANEXO I - Prancha Roubo dos Biscoitos

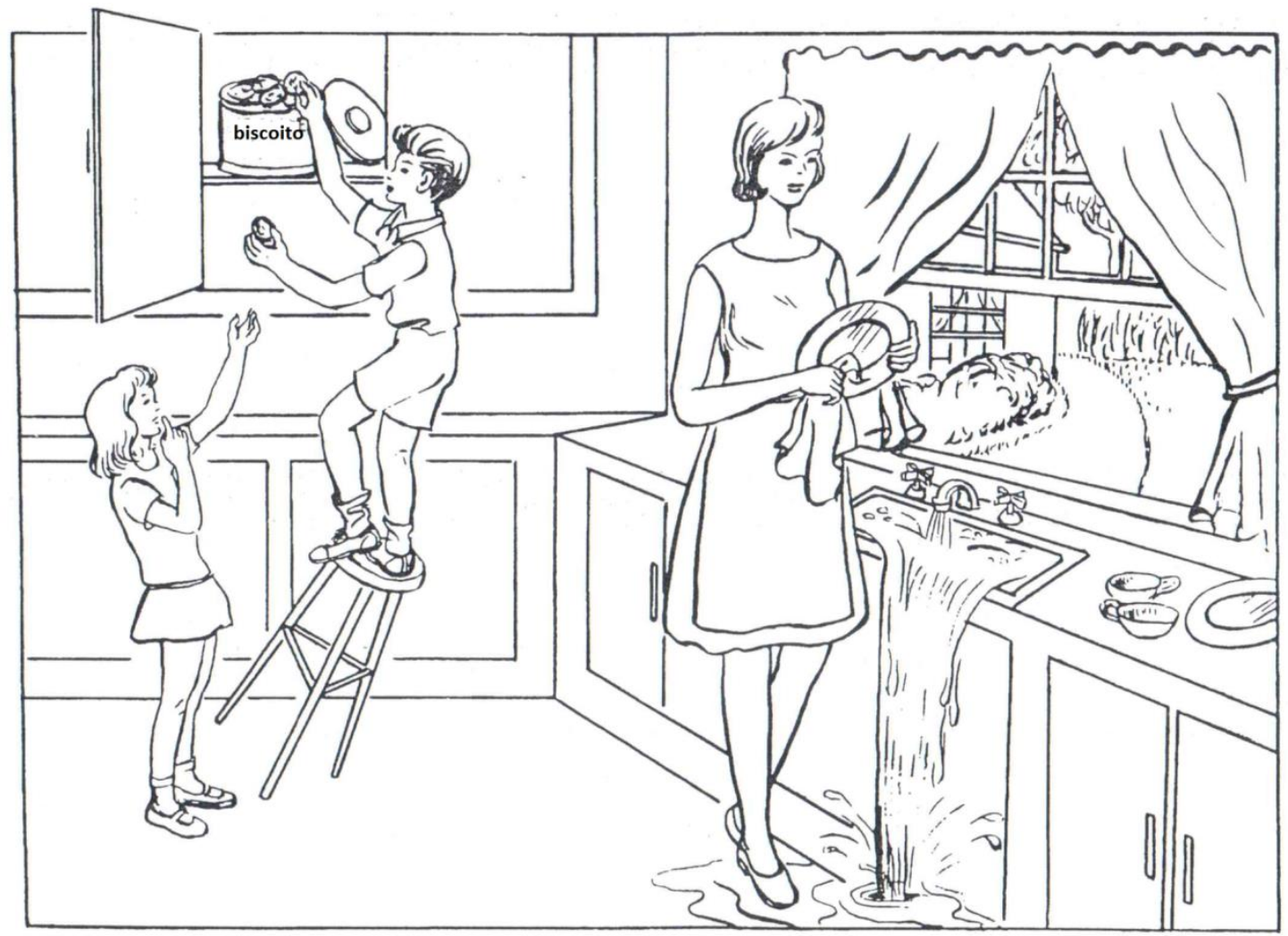




\section{ANEXO J - Cenas da história da Cinderela}

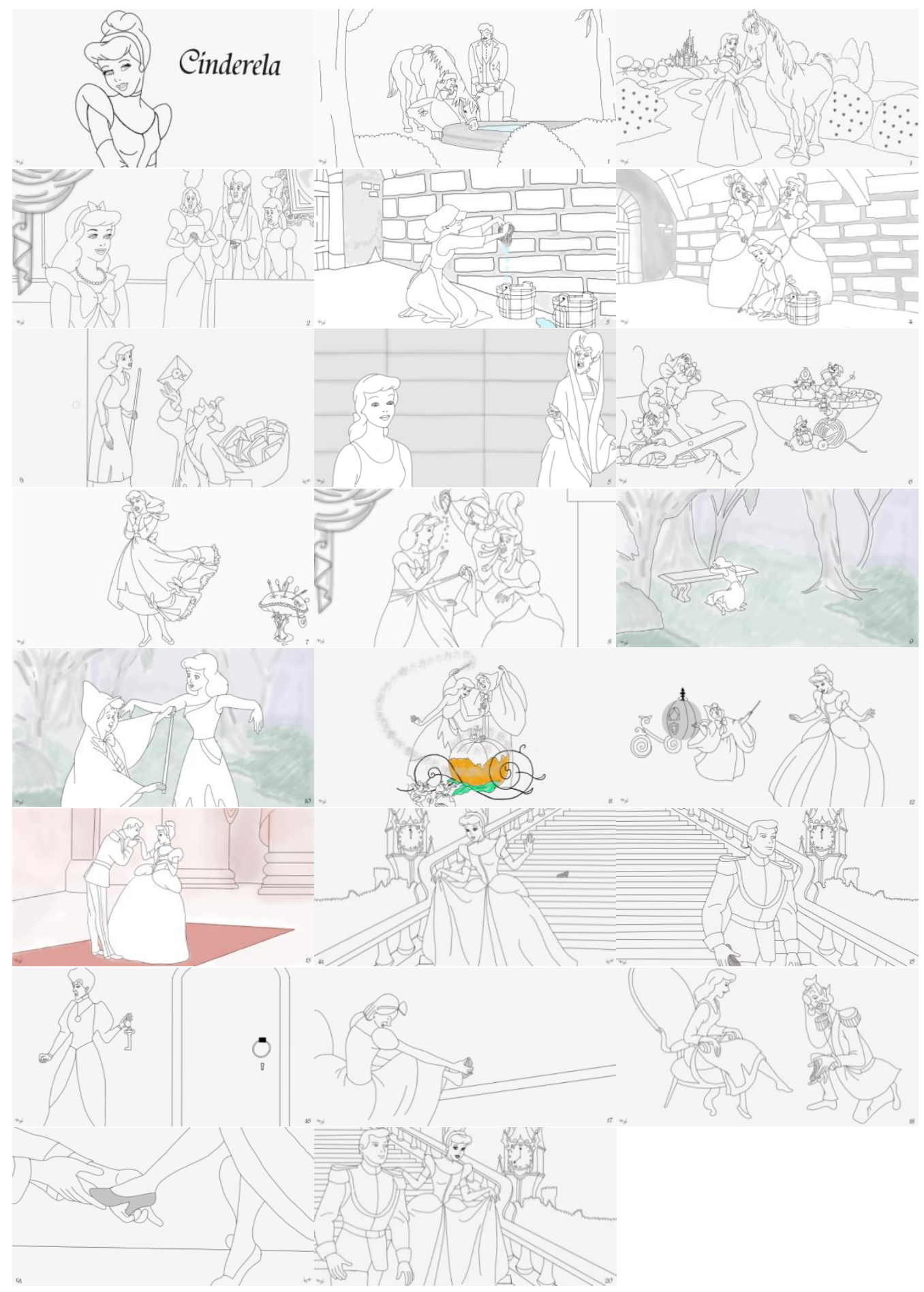


ANEXO K - Critérios para transcrição - princípios do NURC/SP No. 338EF e

331D2

Normas para Transcrição

\begin{tabular}{|c|c|c|}
\hline OCORRÊNCIAS & SINAIS & EXEMPLIFICAÇÃO* \\
\hline $\begin{array}{l}\text { Incompreensão de palavras ou } \\
\text { segmentos }\end{array}$ & () & $\begin{array}{l}\text { do nível de renda...( ) } \\
\text { nível de renda nominal... }\end{array}$ \\
\hline Hipótese do que se ouviu & (hipótese) & $\begin{array}{l}\text { (estou) meio preocupado (com o } \\
\text { gravador) }\end{array}$ \\
\hline $\begin{array}{l}\text { Truncamento (havendo } \\
\text { homografia, usa-se acento } \\
\text { indicativo da tônica e/ou timbre) }\end{array}$ & l & e comé/ e reinicia \\
\hline Entoação enfática & Maiúscula & porque as pessoas reTÊM moeda \\
\hline $\begin{array}{l}\text { Prolongamento de vogal e } \\
\text { consoante (como s, r) }\end{array}$ & $\begin{array}{c}:: \text { podendo aumentar para :::: ou } \\
\text { mais }\end{array}$ & $\begin{array}{l}\text { ao emprestarem os... éh::: ...o } \\
\text { dinheiro }\end{array}$ \\
\hline Silabação & - & por motivo tran-sa-ção \\
\hline Interrogação & ? & eo Banco... Central... certo? \\
\hline Qualquer pausa & $\ldots$ & $\begin{array}{l}\text { são três motivos... ou três razões... } \\
\text { que fazem com que se retenha } \\
\text { moeda... existe uma... retenção }\end{array}$ \\
\hline $\begin{array}{l}\text { Comentários descritivos do } \\
\text { transcritor }\end{array}$ & ((minúsculas)) & $(($ tossiu $))$ \\
\hline $\begin{array}{l}\text { Comentários que quebram a } \\
\text { seqüência temática da exposição; } \\
\text { desvio temático }\end{array}$ & --- & $\begin{array}{l}\text {... a demanda de moeda -- vamos } \\
\text { dar essa notação -- demanda de } \\
\text { moeda por motivo }\end{array}$ \\
\hline $\begin{array}{l}\text { Superposição, simultaneidade de } \\
\text { vozes }\end{array}$ & $\{$ ligando as linhas & $\begin{array}{l}\text { A. na \{ casa da sua irmã } \\
\text { B. sexta-feira? } \\
\text { A. fizeram }\{\text { lá... } \\
\text { B. cozinharam lá? }\end{array}$ \\
\hline $\begin{array}{l}\text { Indicação de que a fala foi tomada } \\
\text { ou interrompida em determinado }\end{array}$ & (...) & (...) nós vimos que existem... \\
\hline
\end{tabular}




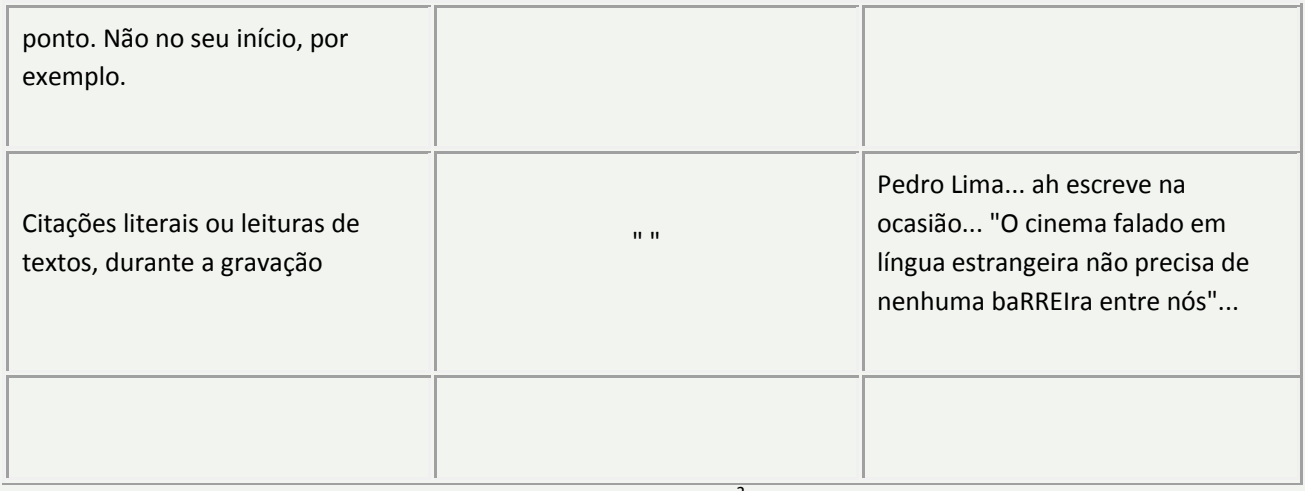

* Exemplos retirados dos inquéritos NURC/SP No. 338 EF e $331 \mathrm{D}^{2}$.

Observações:

1. Iniciais maiúsculas: só para nomes próprios ou para siglas (USP etc.)

2. Fáticos: ah, éh, eh, ahn, ehn, uhn, tá (não por está: tá? você está brava?)

3. Nomes de obras ou nomes comuns estrangeiros são grifados.

4. Números: por extenso.

5. Não se indica o ponto de exclamação (frase exclamativa).

6. Não se anota o cadenciamento da frase.

7. Podem-se combinar sinais. Por exemplo: oh::..... (alongamento e pausa).

8. Não se utilizam sinais de pausa, típicos da língua escrita, como ponto-e-vírgula, ponto final, dois pontos, vírgula. As reticências marcam qualquer tipo de pausa, conforme referido na Introdução. 


\section{REFERÊNCIAS BIBLIOGRÁFICAS}

Aluísio SM, Pelizzoni JM, Marchi AR, Oliveira IH, Manenti R, Marquivafável V. An account of the challenge of tagging a reference corpus of Brazilian Portuguese. In: PROPOR' 2003, 2003, Faro. Lecture Notes on Artificial Intelligence. Proceedings of PROPOR' 2003. Springer Verlag, 2003. v.1.

Armstrong E. Aphasic discourse analysis: The story so far. Aphasiology, 2000; 14(9): 875-892.

Ardila A. The major aphasic syndromes: Wernicke's aphasia and Broca's afasia. In: Ardila A. Aphasia Handbook. Florida University. Flórida. 2014: 60-71.

Berko-Gleason J, Goodglass H, Obler L, Green E, Hyde M, Weintraub S. Narrative strategies of aphasics and normal-speaking subjects. Journal of Speech and Hearing Research, 1980, 23, 370-382.

Berthier ML, García Casaresa N, Dávila G. Afasias y trastornos del habla. Medicine. 2011;10(74):5035-4.

Bird H, Franklin S. Cinderella revisited: A comparison of fluent and non-fluent aphasic speech. J. Neurolinguistics, 1995/6;9(3):187-206.

Brucki SM, Rocha MS. Category fluency test: effects of age, gender and education on total scores, clustering and switching in Brazilian Portuguesespeaking subjects. Braz J MedBiol Res. 2004;37(12):1771-7.

Bulhões JSU. Levantamento, análise e descrição de elementos paralinguísticos do português espontâneo. Dissertação de mestrado. Pará. Universidade Federal do Pará. 2006:202p.

Cannizzaro MS, Coelho CA, Analysis of Narrative Discourse Structure as an Ecologically Relevant Measure of Executive Function in Adults. J Psycholinguist Res. 2013;42:1-23.

Chun RYS. Processos de significação de afásicos usuários de comunicação suplementar e/ou alternativa . Rev Soc Bras Fonoaudiol. 2010;15(4):598-603.

Cunha AL. Coh-Metrix-Dementia: análise automática de distúrbios de linguagem nas demências utilizando Processamento de Línguas Naturais. 2015. Dissertação de Mestrado - Universidade de São Paulo (USP). Instituto de Ciências Matemáticas e de Computação São Carlos.

Davis AG, O'neil-Pirozzi TM, Coon M. Referential cohesion and logical coherence of narration after right hemisphere stroke. Brain Lang. 1997; 56:183210. 
Duffy JR. Differential Diagnosis. In: Duffy JR. Motor Speech Disorders. St. Louis. Elsevier. 2013;355-375.

Duong A, Tardif A, Ska B. Discourse about discourse: What is it and how does it progress in Alzheimer's disease? Brain Cogn. 2003;53:177-80.

Faroqi-Shah Y, Thompson CK. Verb inflections in agrammatic aphasia: Encoding of tense features. J Mem Lang. 2007, 56:129-151.

Fergadiotis $G$ et al. Measuring Lexical Diversity in Narrative Discourse of People With Aphasia. Am J Speech Lang Pathol. 2013; 22(2):S397-40.

Fraser KC, Meltzer JA, Graham NL, Leonard C, Hirst G, Black SE, Rochon E. Automated classification of primary progressive aphasia subtypes from narrative speech transcripts. Cortex. 2014;55:43-60.

Glosser G, Deser T. Patterns of discourse production among neurological patients with fluent language disorders. Brain Lang. 1990;40:67-88.

Goodglass H, Kaplan E, Barresi, B. The Assessment of Aphasia and Related Disorders. Philadelphia: Lippincott Williams\& Wilkins; 2001.

Goodglass, H., Christiansen, J.A. \& Gallagher, R. (1993). Comparison of morphology and syntax in free narrative and structured tests: Fluent vs nonfluent aphasics. Cortex, 29, 377-407.

Hallowell B, Chapey R. Introduction in Language Intervention Strategies in adult aphasia. In: Chapey R. Language Intervention Strategies in aphasia and Related Communication Disorders. 5ft ed. Philadelphia. Wolters-Kluwe, Lippincott, Williams \& Wilkins. 2008:3-19.

Kintsch W, van Dijk T. Towards a model of text comprehension and production. Psychol Rev, 1978;85:363-394.

Machado TH, Charchat-Fichman H, Santos EL, Carvalho VA, Fialho PP, Koenig AM, Fernandes SC, Lourenço RA, Paradela EMP, Caramelli P. Normative data for healthy elderly on the phonemic verbal fluency task - FAS. Dement Neuropsychol. 2009;3(1):55-60.

MacWhinney B. The CHILDES Project: Tools for Analyzing Talk. Erlbau, Associates, 3a edição. Mahwah, NJ: Lawrence, 2000.

MacWhinney B et al. Aphasia Bank: Methods for Studying Discourse. Aphasiology, 2011; 25(11): 1286-1307.

MacWhinney B et al. Automated analysis of the Cinderella story. Aphasiology, 2010; 24(6): 856-868. 
Mansur LL, Radanovic M. Avaliação da comunicação nas doenças de etiologia neurológica. In: Mansur LL, Radanovic, M. Neurolinguística: princípios para a prática clínica. São Paulo: El - Edições Inteligentes. 2004:247-276.

Medeiros JSF et al. Análise do discurso de indivíduos afásicos fluentes e com leve dificuldade de compreensão oral. Rev. CEFAC. 2016 Maio-Jun; 18(3):704720.

Miceli G, Silveri MC, Romani C, Caramazza A. (1989). Variation in the patterns of omissions and substitutions of grammatical morphemes in the spontaneous speech of so-called agrammatic patients. Brain Lang, 36, 447-492.

Mross EF. Text analysis: macro and microstructural aspects of discourse processing. In: Joanette $\mathrm{Y}$, Brownell HH (eds). Discourse Ability and Brain Damage. New York. Springer-Verlag. 1990:51-68.

NCHSoftware. Express Scribe transcription play-back software. http://www.nch.com.au/scribe/,07.05.2009.

Nicholas M, Obler KO, Albert ML, Helm-Estabrooks. Empty speech in Alzheimer's disease and fluent aphasia. J. Speech Hear. Res. 1985;28:405-10.

Nicholas LE, Brookshire $\mathrm{RH}$. A system for quantifying the informativeness and efficiency of the connected speech of adults with aphasia. J Speech Hear Res. 1993; 36:338-50.

Nitrini R, Caramelli P, Bottino CM, Damasceno BP, Brucki SM, Anghinah R, Academia Brasileira de Neurologia. Diagnosis of Alzheimer's disease in Brazil: cognitive and functional evaluation. Recommendations of the Scientific Department of Cognitive Neurology and Aging of the Brazilian Academy of Neurology. Arq Neuropsiquiatr 2005;63(3A):720-7.

Pacheco MC, Pinto RCN. Aspectos discursivos da narrativa de um sujeito afásico fluente. ESTUDOS LINGUÍ́sTICOS, São Paulo, 39 (2): p. 568-577, mai.-ago. 2010.

Radanovic, M. Acidente Vascular Encefálico. In: Radanovic, M. Neurologia básica para profissionais da área de saúde. São Paulo. Editora Atheneu, 2015. Cap. 6 - pp $105-123$.

Roberts J, Wertz RT (1989). Comparison of spontaneous and elicited oralexpressive language in aphasia. Clinical Aphasiology, 18, 479-488.

Rochon E. et. al. Quantitative Analysis of Aphasic Sentence Production: Further Development and New Data. Brain Lang, 2000;72:193-218.

Saffran, E.M., Sloan-Berndt, R. \& Schwartz, M. (1989). The quantitative analysis of agrammatic production: Procedure and data. Brain and Language, $37,440 \pm 479$. 
Scarton C, Aluísio S. Análise da Inteligibilidade de textos via ferramentas de Processamento de Língua Natural: adaptando as métricas do Coh-Metrix para o Português. Linguamática, 2010; 2(1):45-62.

Schwartz MF, Saffran EM, Bloch DE, Dell GS. (1994). Disordered speech production in aphasic and normal speakers. Brain Lang, 47, 52-88.

Ska B, Duong A, Joanette Y. Discourse impairments. In: Kent RD. The MIT encyclopedia of communication disorders. Cambridge, MA: MIT Press; 2004. p. 302-304.

Silveira G, Mansur LL. Analysis of prototypical narratives produced by aphasic individuals and cognitively healthy subjects. Dement Neuropsychol 2015 September;9(3):279-284.

Sitek EJ et al. Neuroimaging in the Differential Diagnosis of Primary Progressive Aphasia - Illustrative Case Series in the Light of New Diagnostic Criteria. Pol J Radiol, 2014; 79: 251-258.

Smith GE, Ivnik RJ. Normative neuropsychology. In: Petersen RC: Mild Cognitive Impairment, New York: Oxford, 2003:63-88.

Stark JA. Content analysis of the fairy tale Cinderella - A longitudinal singlecase study of narrative production: "From rags to riches". Aphasiology, 2010;24:6-8:709-724.

Stark JA. Viola MS. Cinderella, Cinderella! Longitudinal analysis of qualitative and quantitative aspects of seven tellings of Cinderella by a Broca's aphasic. Brain Lang.2007; 103:234-235.

Stenetorp P, Pyysalo S, Topić G, Ohta T, Ananiadou S, Tsujii J. Brat: a Webbased Tool for NLP-Assisted Text Annotation. In Proceedings of the 13th Conference of the European Chapter of the Association for Computational Linguistics, pages 102-107, Avignon, France, April 23 - 272012 (Demo Session).

Thompson CK et al. Dissociations Between Fluency And Agrammatism In Primary Progressive Aphasia. Aphasiology, 2012;26(1):20-43.

Toledo CM, Cunha ALV, Scarton C, Aluísio S. Automatic classification of written descriptions by healthy adults: an overview of the application of natural language processing and machine learning techniques to clinical discourse analysis. Dement Neuropsychol 2014; 8(3): 227-235.

Valotassiou V et al. Brain Perfusion SPECT with Brodmann Areas Analysis in Differentiating Frontotemporal Dementia Subtypes. Current Alzheimer Research, 2014, 11, 941-954. 
Yamada $\mathrm{N}$ et al. Atomoxetine administration combined with intensive speech therapy for post-stroke aphasia: evaluation by a novel SPECT method. Current Alzheimer Research, 2014, Vol. 11, No. 10. 
